\title{
Magnesiation of Aryl Fluorides Catalyzed by a Rhodium-Aluminum Complex
}

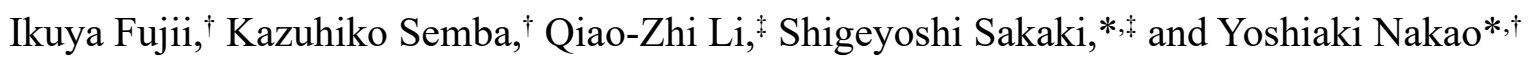

\author{
${ }^{\dagger}$ Department of Material Chemistry, Graduate School of Engineering, Kyoto University, \\ Nishikyo-ku, Kyoto 615-8510, Japan
}

${ }^{\ddagger}$ Fukui Institute for Fundamental Chemistry, Kyoto University, Sakyo-ku, Kyoto 606-8103, Japan sakaki.shigeyoshi.47e@st.kyoto-u.ac.jp; nakao.yoshiaki.8n@kyoto-u.ac.jp

General. All manipulations of oxygen- and moisture-sensitive materials were conducted with a standard schlenk technique under an argon atmosphere or in a glove box under a nitrogen atmosphere. Medium pressure liquid chromatography (MPLC) was performed using Kanto Chemical silica gel 60 (spherical, 40-50 $\mu \mathrm{m}$ ), Biotage ${ }^{\circledR}$ SNAP Ultra, or Biotage ${ }^{\circledR}$ Sfär Silica High Capacity Duo. Analytical thin layer chromatography (TLC) was performed on Merck TLC silica gel $60 \mathrm{~F}_{254}(0.25 \mathrm{~mm})$ plates. Visualization was accomplished with UV light (254 nm).

Apparatus. Proton, boron, carbon, fluorine, and phosphorus nuclear magnetic resonance spectra $\left({ }^{1} \mathrm{H}\right.$, ${ }^{2} \mathrm{H},{ }^{11} \mathrm{~B},{ }^{13} \mathrm{C},{ }^{19} \mathrm{~F}$, and ${ }^{31} \mathrm{P}$ NMR) were recorded on a JEOL ECS-400 $\left({ }^{1} \mathrm{H}\right.$ NMR, $400 \mathrm{MHz}$; ${ }^{2} \mathrm{H}$ NMR $61 \mathrm{MHz} ;{ }^{11} \mathrm{~B}$ NMR, $128 \mathrm{MHz} ;{ }^{13} \mathrm{C} \mathrm{NMR} 101 \mathrm{MHz} ;{ }^{19} \mathrm{~F} \mathrm{NMR} 376 \mathrm{~Hz} ;{ }^{31} \mathrm{P}$ NMR $162 \mathrm{MHz}$ ) spectrometer with solvent resonance as the internal standard $\left({ }^{1} \mathrm{H} \mathrm{NMR}, \mathrm{CDCl}_{3}\right.$ at $7.26 \mathrm{ppm}, \mathrm{C}_{6} \mathrm{D}_{6}$ at $7.16 \mathrm{ppm},\left(\mathrm{CD}_{3}\right)_{2} \mathrm{SO}$ at $2.49 \mathrm{ppm}, \mathrm{CD}_{2} \mathrm{Cl}_{2}$ at $5.32 \mathrm{ppm} ;{ }^{13} \mathrm{C} \mathrm{NMR}, \mathrm{CDCl}_{3}$ at $77.0 \mathrm{ppm}, \mathrm{C}_{6} \mathrm{D}_{6}$ at 128.0 ppm, $\left(\mathrm{CD}_{3}\right)_{2} \mathrm{SO}$ at $39.5 \mathrm{ppm}$. NMR data are reported as follows: chemical shift, multiplicity $(\mathrm{s}=$ singlet, $\mathrm{d}=$ doublet, $\mathrm{t}=$ triplet, $\mathrm{q}=$ quartet, quint $=$ quintet, sext $=$ sextet, sept $=$ septet, $\mathrm{br}=$ broad, $\mathrm{m}$ $=$ multiplet, $\mathrm{vt}=$ virtual triplet $)$, coupling constants $(\mathrm{Hz})$, and integration. High-resolution mass spectra were obtained with Thermo Fischer Scientific MS: Exactive Plus HPLC: UltiMate 3000 (ESI) and Bruker Daltonics ultraflexXtreme (MALDI). Medium pressure liquid chromatography (MPLC) was performed with a Yamazen EPLC-W-Prep 2XY. Elemental analyses were performed on a JScience Micro corder JM11, and a YANACO Micro corder MT-5. IR analysis was performed on an Agilent Cary 630 FTIR spectrometer.

Chemicals. Unless otherwise noted, commercially available chemicals were distilled under argon atmosphere in the presence of $\mathrm{CaH}_{2}$ and stored in a glovebox. If commercially available chemicals are solids, the chemicals are used without purification. $\mathrm{AlCl}_{3}$ (99.999\%) was purchased from Aldrich and used without further purification. $\mathrm{Pd} / \mathrm{C}$ and paraformaldehyde were purchased from Wako Pure Chemical Industries. These were used without further purification. Diphenylphosphine was purchased from Tokyo Chemical Industry Co., Ltd.. Aluminum-rhodium bimetallic complexes $\mathbf{2 a}^{1}$ was prepared according to literature procedures. $[\mathrm{Rh}(\mathrm{nbd})(\mu-\mathrm{Cl})]_{2}(\mathrm{nbd}=2,5 \text {-norbornadiene })^{2}$ was synthesized following the reported procedures. Anhydrous hexane, toluene and THF were purchased 
from Kanto Chemical and purified by passage through activated alumina under positive argon pressure as described by Grubbs et al.. ${ }^{3}$ Magnesium powder used for reductant was purchased from Sigma-Aldrich (product number 13112) or Alfa Aesar (product number 10233). All other commercially available reagents were purchased from common sources (e.g. Tokyo Chemical Industry Co., Ltd., FUJIFILM Wako Pure Chemical Corporation, Sigma-Aldrich, Alfa-Aesar, Nacalai Tesque INC. etc.).<smiles>Fc1ccccc1</smiles>

$3 a$<smiles>CS(=O)(=O)c1ccc(F)cc1</smiles>

$3 f$<smiles>CN(C)c1ccc(F)cc1</smiles>

$3 m$<smiles>O=C(O)c1cccc2ccccc12</smiles>

$5 a$<smiles>CS(=O)(=O)c1ccc(C(=O)O)cc1</smiles>
$5 f$<smiles>[2H]c1cccc2ccccc12</smiles>
$5 k$<smiles>Fc1cccc2ccccc12</smiles>

$3 b$<smiles>Cc1cccc(F)c1</smiles>

$3 g$<smiles>Cc1ccc(F)cc1</smiles><smiles>Fc1ccc(-c2ccccc2)cc1</smiles>

3h<smiles>Fc1ccc(Br)cc1</smiles><smiles>Cc1ccccc1F</smiles>

$3 \mathbf{i}$<smiles>COc1ccc(F)cc1</smiles>

$3 j$<smiles>O=C(O)c1ccccc1</smiles>

$5 b$<smiles>Cc1ccc(C(=O)O)cc1</smiles>

$5 c$<smiles>O=C(O)c1ccc(Br)cc1</smiles>

$5 d$<smiles>COc1ccc(C(=O)O)cc1</smiles>

5 e<smiles>Cc1cccc(C)c1C(=O)O</smiles>

$5 \mathbf{j}$<smiles>O=C(O)c1ccc(-c2ccccc2)cc1</smiles>

$5 h$<smiles>CN(C)c1ccc(C(=O)c2ccccc2)cc1</smiles>

$5 \mathrm{~m}$

Figure S1. List of fluoroarenes $\mathbf{3}$ and products $\mathbf{5}$ in this study. 
Procedures for Scheme 1.

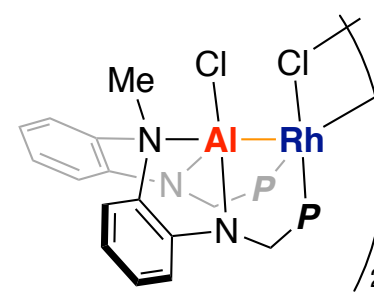

2a, $0.30 \mathrm{mmol}$ $\boldsymbol{P}=\mathrm{P}(i-\mathrm{Pr})_{2}$<smiles>Fc1ccccc1</smiles>

$3 a, 0.60 \mathrm{mmol}$

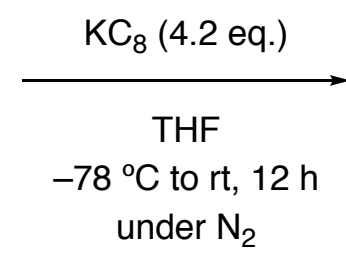

under $\mathrm{N}_{2}$

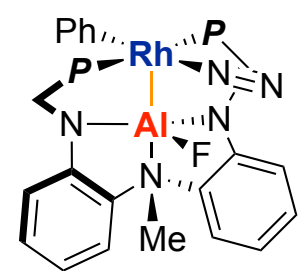

$4 a, 95 \%$

To a THF (5.0 mL) solution of $\mathbf{2 a}(403 \mathrm{mg}, 0.30 \mathrm{mmol})$ and fluorobenzene (3a, $58 \mathrm{mg}, 0.60 \mathrm{mmol})$, a suspension of potassium graphite $(176 \mathrm{mg}, 1.3 \mathrm{mmol})$ in THF $(5.0 \mathrm{~mL})$ was slowly added at $-78^{\circ} \mathrm{C}$. The mixture was warmed up to room temperature and stirred for $12 \mathrm{~h}$ at the same temperature. After the reaction, THF was evaporated and benzene $(10 \mathrm{~mL})$ was added to the residue. After filtration through a KIRIYAMA filter paper (No. 5A), the filtrate was concentrated to afford a brown precipitate. The precipitate was washed with $n$-pentane $(3.0 \mathrm{~mL} \mathrm{x} \mathrm{2)}$ and dried under reduced pressure to give $4 \mathbf{a}$ as a brown solid in $95 \%$ yield. Yellow crystals of $\mathbf{4 a}$ for X-ray crystallography were obtained from a saturated $n$-pentane solution of $\mathbf{4 a}$ at $-35^{\circ} \mathrm{C}$.

4a: ${ }^{1} \mathrm{H}$ NMR (400 MHz, $\left.\mathrm{C}_{6} \mathrm{D}_{6}, 24{ }^{\circ} \mathrm{C}\right): \delta 0.77(\mathrm{q}, J=6.1 \mathrm{~Hz}, 6 \mathrm{H}), 0.95(\mathrm{q}, J=7.0 \mathrm{~Hz}, 6 \mathrm{H}), 1.06(\mathrm{q}, J$ $=6.7 \mathrm{~Hz}, 6 \mathrm{H}), 1.25(\mathrm{q}, J=6.7 \mathrm{~Hz}, 6 \mathrm{H}), 1.48(\mathrm{br} \mathrm{s}, 2 \mathrm{H}), 2.42(\mathrm{br} \mathrm{s}, 2 \mathrm{H}), 3.14(\mathrm{~s}, 3 \mathrm{H}), 3.15(\mathrm{~d}, J=12.8$ $\mathrm{Hz}, 2 \mathrm{H}), 3.30(\mathrm{~d}, J=12.8 \mathrm{~Hz}, 2 \mathrm{H}), 6.56-6.62(\mathrm{~m}, 3 \mathrm{H}), 6.65-6.72(\mathrm{~m}, 3 \mathrm{H}), 6.91(\mathrm{t}, J=7.3 \mathrm{~Hz}, 1 \mathrm{H})$, $7.19(\mathrm{t}, J=7.3 \mathrm{~Hz}, 3 \mathrm{H}), 7.36(\mathrm{~d}, J=7.3 \mathrm{~Hz}, 2 \mathrm{H}), 7.68(\mathrm{~d}, J=7.3 \mathrm{~Hz}, 1 \mathrm{H}) .{ }^{13} \mathrm{C}\left\{{ }^{1} \mathrm{H}\right\} \mathrm{NMR}(101 \mathrm{MHz}$, $\left.\mathrm{C}_{6} \mathrm{D}_{6}, 24^{\circ} \mathrm{C}\right): \delta 18.0,19.9$ (two signals were overlapped), 20.2, $22.7(\mathrm{~d}, J=11.6 \mathrm{~Hz}), 22.8(\mathrm{~d}, J=$ $10.4 \mathrm{~Hz}$ ), 23.3 (d, $J=9.3 \mathrm{~Hz}), 23.4(\mathrm{~d}, J=9.3 \mathrm{~Hz}), 41.5(\mathrm{~d}, J=19.7 \mathrm{~Hz}), 41.7(\mathrm{~d}, J=19.7 \mathrm{~Hz}), 47.5$ $(\mathrm{d}, J=8.1 \mathrm{~Hz}), 110.3,114.3,121.5,123.0,125.6,127.9,128.6,132.0,137.2,137.7,151.0(\mathrm{t}, J=8.1$ $\mathrm{Hz}) .{ }^{31} \mathrm{P}\left\{{ }^{1} \mathrm{H}\right\} \mathrm{NMR}\left(162 \mathrm{MHz}, \mathrm{C}_{6} \mathrm{D}_{6}, 24{ }^{\circ} \mathrm{C}\right): \delta 39.9\left(\mathrm{~d}, J_{\mathrm{P}-\mathrm{Rh}}=144 \mathrm{~Hz}\right) .{ }^{19} \mathrm{~F}\left\{{ }^{1} \mathrm{H}\right\} \mathrm{NMR}(376 \mathrm{MHz}$, THF- $d 8,24^{\circ} \mathrm{C}$ ): $\delta-149$ (br). The signal of fluorine directly attached to the aluminum atom was broadened due to quadrupolar relaxation. IR (solid state): $v_{\mathrm{NN}}=2214 \mathrm{~cm}^{-1}$. m.p. $170{ }^{\circ} \mathrm{C}$ (decomp.). MALDI-MS $\mathrm{C}_{33} \mathrm{H}_{48} \mathrm{AlFN}_{3} \mathrm{P}_{2} \mathrm{Rh}^{*+}$ : calcd. 697.2172, Found: 697.2172. Anal. Calcd $\mathrm{C}_{33} \mathrm{H}_{48} \mathrm{FN}_{5} \mathrm{P}_{2} \mathrm{AlRh}$ : C, 54.62; H, 6.67; N, 9.65. Found: C, 52.54; H, 7.04; N, 7.07. The experimental values did not agree with calculated values. This is because $\mathrm{N}_{2}$ ligand has come off during vacuum drying. IR spectrum of the crystals of $\mathbf{4 a}$ that were dried in vacuo at room temperature, the strength of absorption of $v_{\mathrm{NN}}\left(2214 \mathrm{~cm}^{-1}\right)$ decreased. 


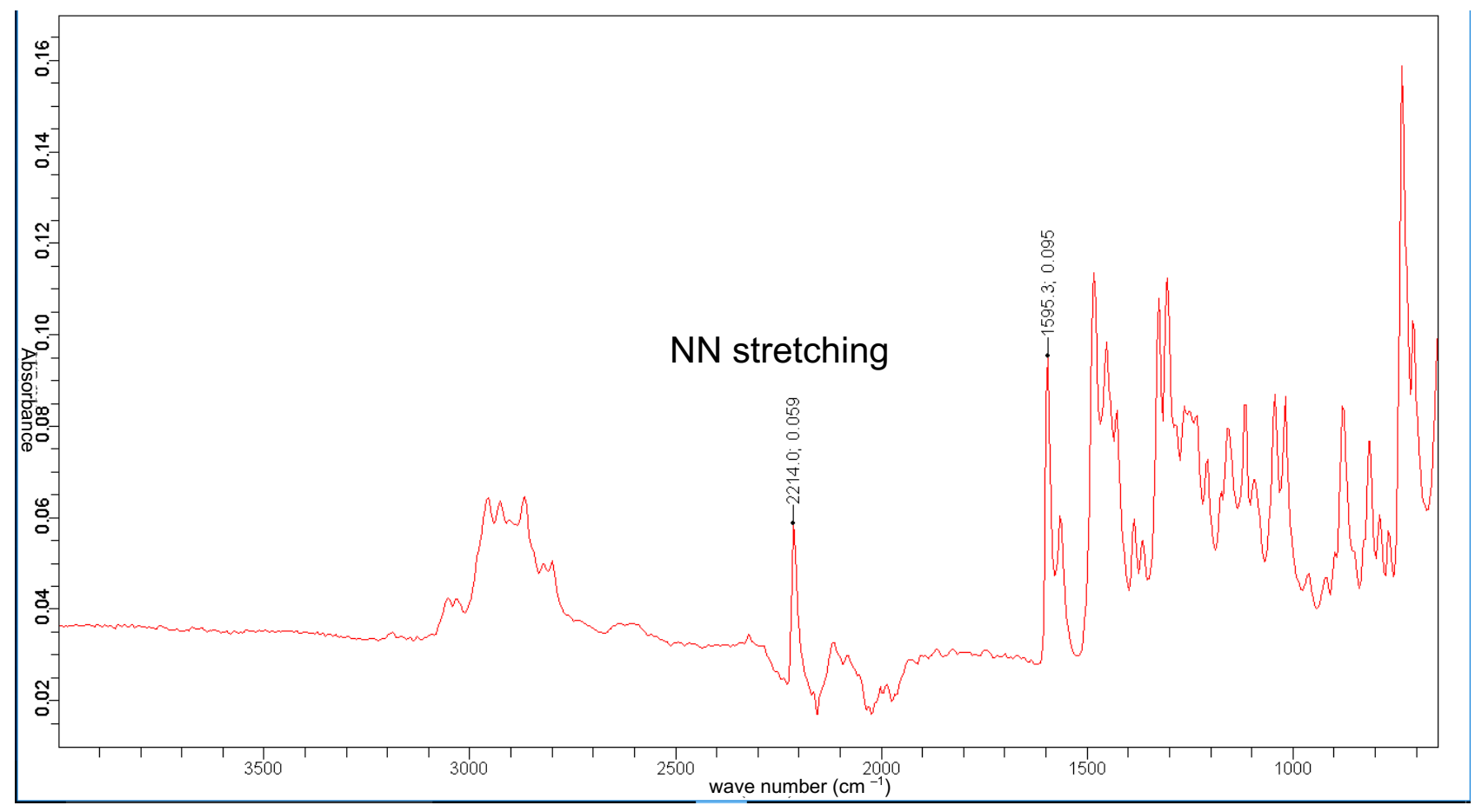

Figure S2. IR spectrum of complex $\mathbf{4 a}$ in solid state.

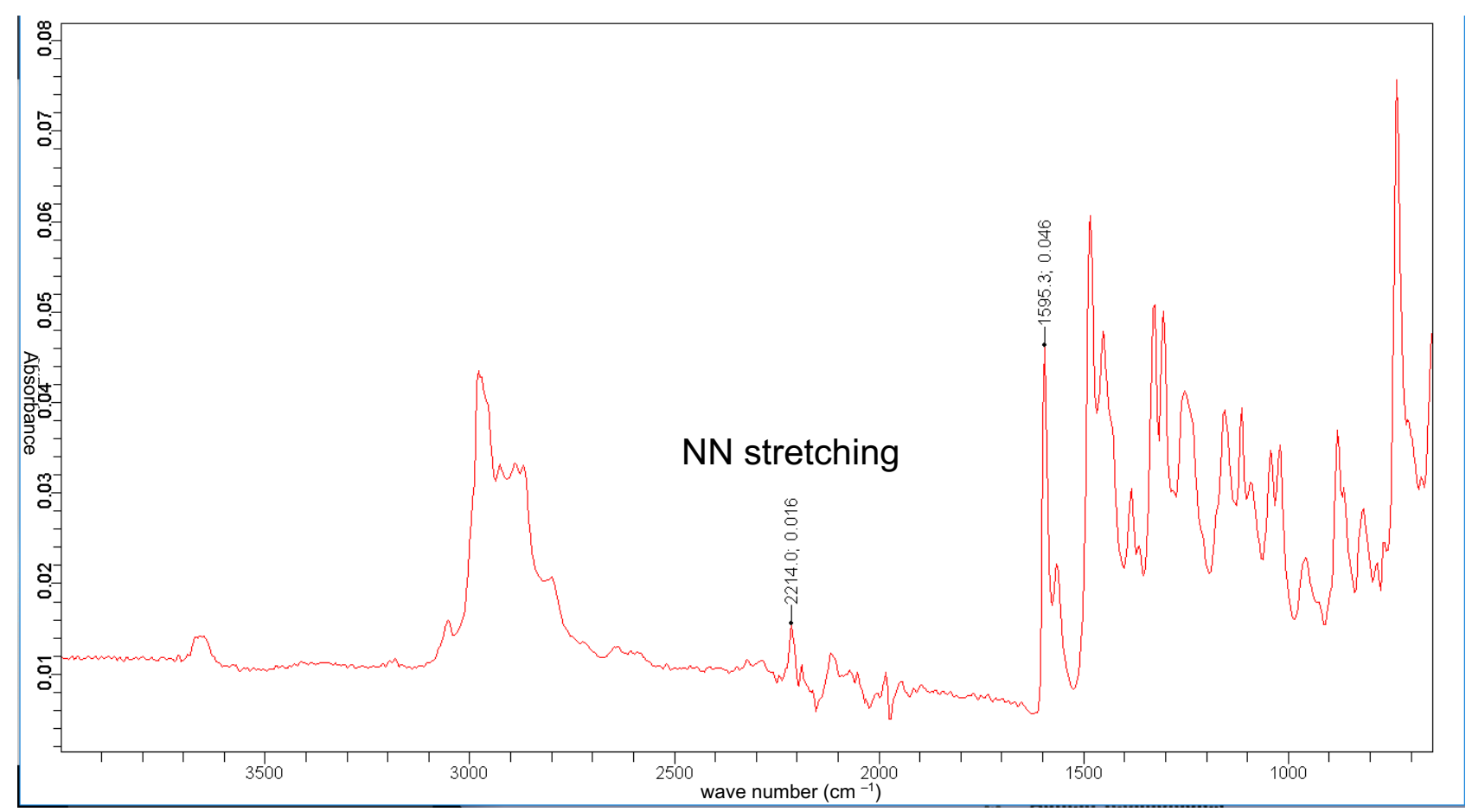

Figure S3. IR spectrum of complex $4 \mathbf{a}$ in solid state after evacuation for $12 \mathrm{~h}$. 


\section{General procedures for Scheme 3.}<smiles>Fc1cccc2ccccc12</smiles>

$3 b, 0.30 \mathrm{mmol}$

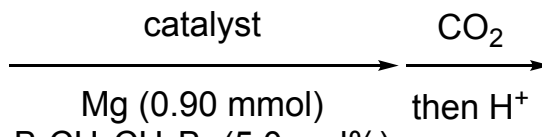
$\mathrm{BrCH}_{2} \mathrm{CH}_{2} \mathrm{Br}(5.0 \mathrm{~mol} \%)$

THF, rt, $22 \mathrm{~h}$<smiles>O=C(O)c1cccc2ccccc12</smiles>

$5 a$

yield of $\mathbf{5 a}$ (conv. of $\mathbf{3 b}$ )

Al-Rh complexes: In a glove box, a $4 \mathrm{~mL}$ vial with a stirring bar was charged with magnesium powder (22 $\mathrm{mg}, 0.90 \mathrm{mmol})$, THF $(500 \mu \mathrm{L})$, and 1,2-dibromoethane $(2.8 \mathrm{mg}, 15 \mu \mathrm{mol})$, and the resulting mixture was stirred for $20 \mathrm{~min}$ at room temperature. 1-Fluoronaphthalene (3b, $44 \mathrm{mg}, 0.30 \mathrm{mmol})$, catalyst $(5.0 \mathrm{~mol} \% \mathrm{Rh})$, and THF $(500 \mu \mathrm{L})$ were put into the vial. The vial was taken out of the glove box and the mixture was stirred for $22 \mathrm{~h}$ at indicated temperature and then, stirred under atmospheric pressure of $\mathrm{CO}_{2}$ at room temperature for $30 \mathrm{~min}$. To the mixture was added $3 \mathrm{M} \mathrm{HCl}$ aq. $(2.0 \mathrm{~mL})$. The mixture was extracted with EtOAc and combined organic layers were washed with $\mathrm{H}_{2} \mathrm{O}$. All of the volatiles were removed by rotary evaporator. Yield of $\mathbf{5 a}$ was determined by ${ }^{1} \mathrm{H}$ NMR spectroscopy with 1,3,5-trimethoxybenzene $(50 \mathrm{mg}, 0.30 \mathrm{mmol})$ as an internal standard.

\section{Al-Rh complexes}

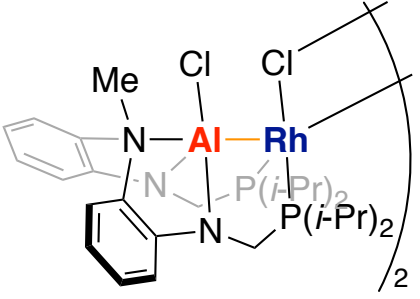

$2 \mathbf{a}$

$88 \%(>95 \%)$

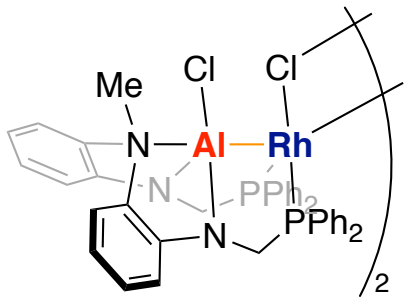

2b (@-15 ㄷ) $89 \%(>95 \%)$ none $<5 \%(<5 \%)$

in situ generated catalysts: In a glove box, a $4 \mathrm{~mL}$ vial (vial $A$ ) with a stirring bar was charged with magnesium powder $(22 \mathrm{mg}, 0.90 \mathrm{mmol})$, THF (500 $\mu \mathrm{L})$, and 1,2-dibromoethane $(2.8 \mathrm{mg}, 15 \mu \mathrm{mol})$, and the resulting mixture was stirred for $20 \mathrm{~min}$ at room temperature. Another vial (vial B) was charged with 3b (44 mg, $0.30 \mathrm{mmol})$, $[\mathrm{Rh}(\mathrm{nbd})(\mu-\mathrm{Cl})]_{2}(3.5 \mathrm{mg}, 8.0 \mu \mathrm{mol}, 2.5 \mathrm{~mol} \%)$, a phosphine ligand $(\mathrm{P} / \mathrm{Rh}=2)$, and THF $(500 \mu \mathrm{L})$ and the resulting mixture was stirred for $10 \mathrm{~min}$ at room temperature. To vial $A$ were added the solution in vial $B$ and $1.03 \mathrm{M} \mathrm{Et}_{2} \mathrm{AlCl}$ in $n$-hexane $(15 \mu \mathrm{L}, 15$ $\mu \mathrm{mol})$. The mixture was stirred for $22 \mathrm{~h}$ at room temperature and then, stirred under atmospheric pressure of $\mathrm{CO}_{2}$ at room temperature for $30 \mathrm{~min}$. To the mixture was added $3 \mathrm{M} \mathrm{HCl}$ aq. $(2.0 \mathrm{~mL})$. The mixture was extracted with EtOAc and combined organic layers were washed with $\mathrm{H}_{2} \mathrm{O}$. All of the volatiles were removed by rotary evaporator. Yield of $\mathbf{5 a}$ was determined by ${ }^{1} \mathrm{H}$ NMR spectroscopy with 1,3,5-trimethoxybenzene $(50 \mathrm{mg}, 0.30 \mathrm{mmol})$ as an internal standard. 
$[\mathbf{R h}(\mathrm{nbd})(\mu-\mathrm{Cl})]_{2}(5.0 \mathrm{~mol} \% \mathbf{R h}) / \mathrm{P}$ ligand $(10 \mathrm{~mol} \% \mathrm{P}) / \mathrm{Et}_{2} \mathrm{AlCl}(20 \mathrm{~mol} \%)$<smiles>c1ccc(P(c2ccccc2)P(c2ccccc2)c2ccccc2)cc1</smiles>

$<5 \%(<5 \%)$<smiles>CC(C)P(C(C)C)C(C)C</smiles>

$<5 \%(<5 \%)$<smiles>Pc1ccccc1-c1ccc2ccccc2c1-c1c(P)ccc2ccccc12</smiles>

$<5 \%(<5 \%)$<smiles>Pc1ccccc1</smiles>

$<5 \%(<5 \%)$<smiles>Pc1ccccc1Oc1ccccc1-c1ccccc1P</smiles>

$<5 \%(<5 \%)$

Lewis acid catalysts: In a glove box, a $4 \mathrm{~mL}$ vial with a stirring bar was charged with magnesium powder $(22 \mathrm{mg}, 0.90 \mathrm{mmol})$, THF $(500 \mu \mathrm{L})$, and 1,2-dibromoethane $(2.8 \mathrm{mg}, 15 \mu \mathrm{mol})$, and the resulting mixture was stirred for $20 \mathrm{~min}$ at room temperature. $3 \mathbf{b}$ (44 $\mathrm{mg}, 0.30 \mathrm{mmol}$ ), Lewis acid (30 $\mu \mathrm{mol})$ and THF $(500 \mu \mathrm{L})$ were put into the vial. The mixture was stirred for $22 \mathrm{~h}$ at room temperature and then stirred under atmospheric pressure of $\mathrm{CO}_{2}$ at room temperature for $30 \mathrm{~min}$. To the mixture was added $3 \mathrm{M} \mathrm{HCl}$ aq. $(2.0 \mathrm{~mL})$. The mixture was extracted with EtOAc and combined organic layers were washed with $\mathrm{H}_{2} \mathrm{O}$. All of the volatiles were removed by rotary evaporator. Yield of 5a was determined by ${ }^{1} \mathrm{H}$ NMR spectroscopy with 1,3,5-trimethoxybenzene (50 $\left.\mathrm{mg}, 0.30 \mathrm{mmol}\right)$ as an internal standard.

\section{Lewis acids}

$\left.\mathrm{AlCl}_{3} \quad \mathrm{AlEt}_{2} \mathrm{Cl} \mathrm{Cl}_{6} \mathrm{~F}_{5}\right)_{3}$

others: In a glove box, a $4 \mathrm{~mL}$ vial with a stirring bar was charged with magnesium source and an additive, and THF $(500 \mu \mathrm{L})$. The resulting mixture was stirred for $20 \mathrm{~min}$ at the room temperature. 3b $(44 \mathrm{mg}, 0.30 \mathrm{mmol})$ and THF $(500 \mu \mathrm{L})$ were put into the vial. The mixture was stirred for $22 \mathrm{~h}$ at room temperature and then, stirred under atmospheric pressure of $\mathrm{CO}_{2}$ at room temperature for 30 min. To the mixture was added $3 \mathrm{M} \mathrm{HCl}$ aq. $(2.0 \mathrm{~mL})$. The mixture was extracted with EtOAc and combined organic layers were washed with $\mathrm{H}_{2} \mathrm{O}$. All of the volatiles were removed by rotary evaporator. Yield of 5a was determined by ${ }^{1} \mathrm{H}$ NMR spectroscopy with 1,3,5-trimethoxybenzene (50 $\mathrm{mg}, 0.30 \mathrm{mmol}$ ) as an internal standard. 


\section{others}

$\mathrm{Mg}$ powder $(0.90 \mathrm{mmol})$

$\mathrm{LiCl}(0.90 \mathrm{mmol})$

$\mathrm{BrCH}_{2} \mathrm{CH}_{2} \mathrm{Br}(5.0 \mathrm{~mol} \%)$

$<5 \%(<5 \%)$
Mg powder $(0.90 \mathrm{mmol})$<smiles>c1ccc2cc3ccccc3cc2c1</smiles>

(10 mol\%)
i-PrMgCl $(0.30 \mathrm{mmol})$ $\mathrm{LiCl}(0.90 \mathrm{mmol})$

$<5 \%(<5 \%)$

$10 \%(12 \%)$ instead of $3 b$

$3 a$ i-PrMgCl $(0.30 \mathrm{mmol})$ $\mathrm{LiCl}(0.90 \mathrm{mmol})$

under argon atmosphere: In a glove box, a $20 \mathrm{~mL}$ Schlenk tube with a stirring bar was charged with magnesium powder (22 mg, $0.90 \mathrm{mmol})$, THF $(500 \mu \mathrm{L})$, and 1,2-dibromoethane $(2.8 \mathrm{mg}, 15 \mu \mathrm{mol})$, and the resulting mixture was stirred for $20 \mathrm{~min}$ at room temperature. 4-Fluorotoluene (3c, $44 \mathrm{mg}$, $0.30 \mathrm{mmol}), \mathbf{2 b}(12 \mathrm{mg}, 8.0 \mu \mathrm{mol})$, and THF $(500 \mu \mathrm{L})$ were put into the Schlenk tube and then, the tube was taken out of the glove box. The tube was evacuated and refilled with argon gas for three times. The mixture was stirred for $22 \mathrm{~h}$ at $-20^{\circ} \mathrm{C}$ and then, stirred under atmospheric pressure of $\mathrm{CO}_{2}$ at room temperature for $30 \mathrm{~min}$. To the mixture was added $3 \mathrm{M} \mathrm{HCl}$ aq. $(2.0 \mathrm{~mL})$. The mixture was extracted with EtOAc and combined organic layers were washed with $\mathrm{H}_{2} \mathrm{O}$. All of the volatiles were removed by rotary evaporator. Yield of 5c was determined by ${ }^{1} \mathrm{H}$ NMR spectroscopy with 1,3,5trimethoxybenzene $(50 \mathrm{mg}, 0.30 \mathbf{m m o l})$ as an internal standard. The corresponding product $\mathbf{5 c}$ was obtained in $73 \%$ yield ( $68 \%$ yield under $\mathrm{N}_{2}$ atmosphere).

magnesium property: In a glove box, a $4 \mathrm{~mL}$ vial with a stirring bar was charged with indicated magnesium (22 mg, $0.90 \mathrm{mmol})$, THF $(500 \mu \mathrm{L})$, and 1,2-dibromoethane (2.8 $\mathrm{mg}, 15 \mu \mathrm{mol})$, and the resulting mixture was stirred for $20 \mathrm{~min}$ at room temperature. $\mathbf{3 c}$ (33 $\mathrm{mg}, 0.30 \mathrm{mmol}), \mathbf{2 b}(12 \mathrm{mg}, 8.0$ $\mu \mathrm{mol})$, and THF $(500 \mu \mathrm{L})$ were put into the vial. The mixture was stirred for $22 \mathrm{~h}$ at $-20{ }^{\circ} \mathrm{C}$ and then, stirred under atmospheric pressure of $\mathrm{CO}_{2}$ at room temperature for $30 \mathrm{~min}$. To the mixture was added $3 \mathrm{M} \mathrm{HCl}$ aq. $(2.0 \mathrm{~mL})$. The mixture was extracted with EtOAc and combined organic layers were washed with $\mathrm{H}_{2} \mathrm{O}$. All of the volatiles were removed by rotary evaporator. Yield of $p$-toluic acid (5c) was determined by ${ }^{1} \mathrm{H}$ NMR spectroscopy with 1,3,5-trimethoxybenzene (50 $\left.\mathrm{mg}, 0.30 \mathrm{mmol}\right)$ as an internal standard.

\begin{tabular}{lcc}
\hline & \\
Supplier (product number) & 16 & 0 \\
Wako (138-13862) wash by $\mathrm{HCl}$ & 30 & 61 \\
Wako (134-13962) & 80 & 5 \\
Sigma Aldrich (13112) & 84 & 5 \\
Alfa Aesar (10233) & & \\
\hline
\end{tabular}

We investigated the purity of Mg powder (Sigma Aldrich; \#13112) that stored in the glove box for 3 months because $\mathrm{Mg}$ could react with dinitrogen to generate magnesium nitride at high temperature. ${ }^{4}$ 
Elemental Analysis, Mg powder: $\mathrm{H}, \mathrm{C}, \mathrm{N}$ were not detected. $\mathrm{Mg}_{3} \mathrm{~N}_{2}$ : calcd. $\mathrm{N}, 27.76$. Found: $\mathrm{C}, 0.15$; $\mathrm{H}, 0.25 ; \mathrm{N}, 24.99$. According to the elemental analysis and the colour of them, the $\mathrm{Mg}$ powder did not contain magnesium nitride.

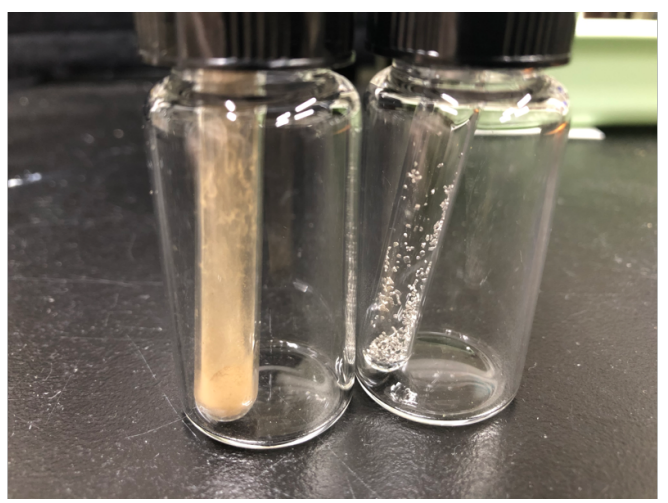

Figure S4. The picture of magnesium nitride (left) and magnesium powder (right). 


\section{General procedures for Scheme 4.}

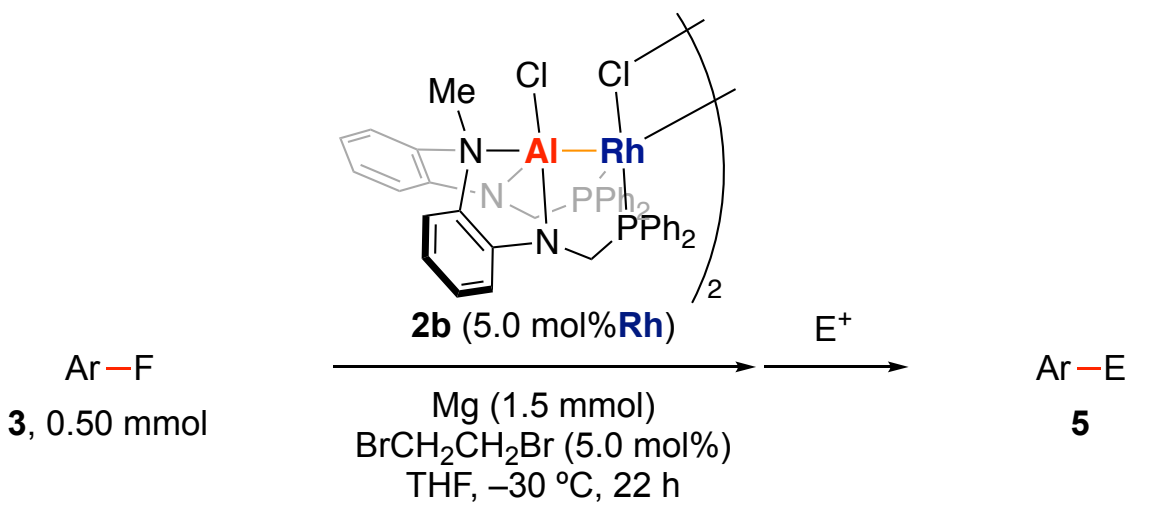

In a glove box, a $4 \mathrm{~mL}$ vial with a stirring bar was charged with magnesium powder (36 $\mathrm{mg}, 1.5$ $\mathrm{mmol})$, THF $(500 \mu \mathrm{L})$, and 1,2-dibromoethane $(4.7 \mathrm{mg}, 25 \mu \mathrm{mol})$, and the resulting mixture was stirred for $20 \mathrm{~min}$ at room temperature. Aryl fluoride $3(0.50 \mathrm{mmol}), \mathbf{2 b}(20 \mathrm{mg}, 13 \mu \mathrm{mol})$, and THF $(1.0 \mathrm{~mL})$ were put into the vial. The mixture was stirred for $22 \mathrm{~h}$ at $-30{ }^{\circ} \mathrm{C}$ and then, reacted with an indicated electrophile.

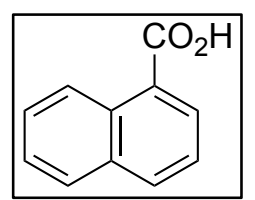

1-Naphthoic acid (5a): The reaction of 1-fluoronaphthalene (3b, $73 \mathrm{mg}, 0.50 \mathrm{mmol})$ at room temperature was followed by being stirred under atmospheric pressure of $\mathrm{CO}_{2}$ at room temperature for $30 \mathrm{~min}$. To the mixture, $3 \mathrm{M} \mathrm{HCl}$ aq. $(2.0 \mathrm{~mL})$ was added. The mixture was extracted with EtOAc and combined organic layers were washed with $\mathrm{H}_{2} \mathrm{O}$. All of the volatiles were removed by rotary evaporator. After MPLC purification (Biotage ${ }^{\circledR}$ SNAP Ultra $25 \mathrm{~g}, n$-hexane:EtOAc $=2: 3$ ), the title compound ( $85 \mathrm{mg}, 0.50 \mathrm{mmol}, 99 \%$ ) was obtained as a white solid. $\mathrm{R}_{\mathrm{f}} 0.59$ (n-hexane/EtOAc $\left.=3: 4\right) .{ }^{1} \mathrm{H} \mathrm{NMR}\left(400 \mathrm{MHz}, \mathrm{CDCl}_{3}, 24{ }^{\circ} \mathrm{C}\right)$ : $\delta 7.54-7.60(\mathrm{~m}, 2 \mathrm{H}), 7.67(\mathrm{t}, J=7.6 \mathrm{~Hz}, 1 \mathrm{H}), 7.93(\mathrm{~d}, J=7.8 \mathrm{~Hz}, 1 \mathrm{H}), 8.11(\mathrm{~d}, J=8.2 \mathrm{~Hz}, 1 \mathrm{H}), 8.43$ $(\mathrm{d}, J=6.9 \mathrm{~Hz}, 1 \mathrm{H}), 9.10(\mathrm{~d}, J=8.4 \mathrm{~Hz}, 1 \mathrm{H}) .{ }^{13} \mathrm{C}\left\{{ }^{1} \mathrm{H}\right\} \mathrm{NMR}\left(101 \mathrm{MHz}, \mathrm{CDCl}_{3}, 24{ }^{\circ} \mathrm{C}\right): \delta 124.5$, $125.5,125.9,126.3,128.1,128.7,131.6,131.9,133.9,134.6,172.9$. All the resonances of ${ }^{1} \mathrm{H}$ and ${ }^{13} \mathrm{C}$ NMR spectra were consistent with the reported values. ${ }^{5}$

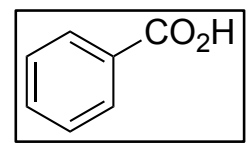

Benzoic acid (5b): The reaction of fluorobenzene (3a, $48 \mathrm{mg}, 0.50 \mathrm{mmol})$ at $-30{ }^{\circ} \mathrm{C}$ was followed by being stirred under atmospheric pressure of $\mathrm{CO}_{2}$ at room temperature for $30 \mathrm{~min}$. To the mixture, $3 \mathrm{M} \mathrm{HCl}$ aq. $(2.0 \mathrm{~mL})$ was added. The mixture was extracted with EtOAc and combined organic layers were washed with $\mathrm{H}_{2} \mathrm{O}$. All of the volatiles were removed by rotary evaporator. After MPLC purification (Biotage ${ }^{\circledR}$ SNAP Ultra $25 \mathrm{~g}, n$-hexane:EtOAc $=2: 3$ ), the title compound ( $53 \mathrm{mg}, 0.43 \mathrm{mmol}, 86 \%)$ was obtained as a white solid. $\mathrm{R}_{\mathrm{f}} 0.53(n-$ hexane/EtOAc = 3:4). ${ }^{1} \mathrm{H} \mathrm{NMR}\left(400 \mathrm{MHz}, \mathrm{CDCl}_{3}, 24^{\circ} \mathrm{C}\right): \delta 7.49(\mathrm{t}, J=7.3 \mathrm{~Hz}, 2 \mathrm{H}), 7.62(\mathrm{t}, J=6.6$ $\mathrm{Hz}, 1 \mathrm{H}), 8.12(\mathrm{~d}, J=7.3 \mathrm{~Hz}, 2 \mathrm{H}) .{ }^{13} \mathrm{C}\left\{{ }^{1} \mathrm{H}\right\} \mathrm{NMR}\left(101 \mathrm{MHz}, \mathrm{CDCl}_{3}, 24{ }^{\circ} \mathrm{C}\right): \delta 128.5,129.3,130.2$, 133.8, 172.3. All the resonances of ${ }^{1} \mathrm{H}$ and ${ }^{13} \mathrm{C}$ NMR spectra were consistent with the reported values. ${ }^{6}$ 


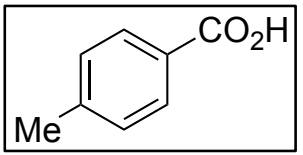

$p$-Toluic acid (5c): The reaction of 4-fluorotoluene (3c, $55 \mathrm{mg}, 0.50 \mathrm{mmol})$ at $30{ }^{\circ} \mathrm{C}$ was followed by being stirred under atmospheric pressure of $\mathrm{CO}_{2}$ at room temperature for $30 \mathrm{~min}$. To the mixture, $3 \mathrm{M} \mathrm{HCl}$ aq. $(2.0 \mathrm{~mL})$ was added. The mixture was extracted with EtOAc and combined organic layers were washed with $\mathrm{H}_{2} \mathrm{O}$. All of the volatiles were removed by rotary evaporator. After MPLC purification ( $25 \mathrm{~g}$ of silica gel, $n$ hexane:EtOAc $=2: 3$ ), the title compound ( $58 \mathrm{mg}, 0.43 \mathrm{mmol}, 86 \%)$ was obtained as a white solid. $\mathrm{R}_{\mathrm{f}}$ $0.56\left(n\right.$-hexane/EtOAc = 3:4). ${ }^{1} \mathrm{H}$ NMR $\left(400 \mathrm{MHz}, \mathrm{CDCl}_{3}, 24^{\circ} \mathrm{C}\right): \delta 2.44(\mathrm{~s}, 3 \mathrm{H}), 7.28(\mathrm{~d}, J=8.2$ $\mathrm{Hz}, 2 \mathrm{H}), 8.00(\mathrm{~d}, J=8.2 \mathrm{~Hz}, 2 \mathrm{H}) .{ }^{13} \mathrm{C}\left\{{ }^{1} \mathrm{H}\right\} \mathrm{NMR}\left(101 \mathrm{MHz}, \mathrm{CDCl}_{3}, 24{ }^{\circ} \mathrm{C}\right): \delta 21.7,126.5,129.2$, 130.3, 144.6, 171.6. All the resonances of ${ }^{1} \mathrm{H}$ and ${ }^{13} \mathrm{C}$ NMR spectra were consistent with the reported values. ${ }^{6}$

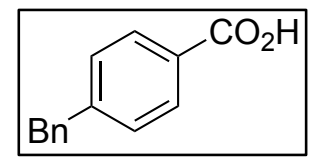

4-Benzylbenzoic acid (5d): The reaction of 1-benzyl-4-fluorobenzene (3d, $93 \mathrm{mg}$, $0.50 \mathrm{mmol}$ ) at $-30{ }^{\circ} \mathrm{C}$ was followed by being stirred under atmospheric pressure of $\mathrm{CO}_{2}$ at room temperature for $30 \mathrm{~min}$. To the mixture, $3 \mathrm{M} \mathrm{HCl}$ aq. $(2.0 \mathrm{~mL})$ was added. The mixture was extracted with EtOAc and combined organic layers were washed with $\mathrm{H}_{2} \mathrm{O}$. All of the volatiles were removed by rotary evaporator. After MPLC purification ( $25 \mathrm{~g}$ of silica gel, $n$-hexane:EtOAc $=1: 1)$, the title compound (105 $\mathrm{mg}, 0.50 \mathrm{mmol}, 99 \%)$ was obtained as a white solid. $\mathrm{R}_{\mathrm{f}} 0.59$ ( $n$-hexane/EtOAc = 3:4). ${ }^{1} \mathrm{H}$ NMR $\left(400 \mathrm{MHz}, \mathrm{CDCl}_{3}, 24{ }^{\circ} \mathrm{C}\right): \delta 4.07(\mathrm{~s}, 2 \mathrm{H}), 7.20(\mathrm{~d}$, $J=6.9 \mathrm{~Hz}, 2 \mathrm{H}), 7.25-7.34(\mathrm{~m}, 5 \mathrm{H}), 8.06(\mathrm{~d}, J=8.2 \mathrm{~Hz}, 2 \mathrm{H}) .{ }^{13} \mathrm{C}\left\{{ }^{1} \mathrm{H}\right\} \mathrm{NMR}\left(101 \mathrm{MHz}, \mathrm{CDCl}_{3}\right.$, $\left.24^{\circ} \mathrm{C}\right): \delta 42.0,126.4,127.2,128.6,129.0,129.1,130.5,139.9,147.6,172.3$. All the resonances of ${ }^{1} \mathrm{H}$ and ${ }^{13} \mathrm{C}$ NMR spectra were consistent with the reported values. ${ }^{7}$

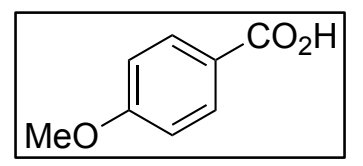

p-Anisic acid (5e): The reaction of 4-fluoroanisole (3e, $63 \mathrm{mg}, 0.50 \mathrm{mmol})$ at $-30{ }^{\circ} \mathrm{C}$ was followed by being stirred under atmospheric pressure of $\mathrm{CO}_{2}$ at room temperature for $30 \mathrm{~min}$. To the mixture, $3 \mathrm{M} \mathrm{HCl}$ aq. $(2.0 \mathrm{~mL})$ was added. The mixture was extracted with EtOAc and combined organic layers were washed with $\mathrm{H}_{2} \mathrm{O}$. All of the volatiles were removed by rotary evaporator. After MPLC purification (Biotage ${ }^{\circledR}$ SNAP Ultra 25 g, $n$-hexane:EtOAc $=2: 3)$, the title compound $(76 \mathrm{mg}, 0.46 \mathrm{mmol}, 91 \%)$ was obtained as a white solid. $\mathrm{R}_{\mathrm{f}} 0.44$ ( $n$-hexane/EtOAc = 3:4). ${ }^{1} \mathrm{H}$ NMR $\left(400 \mathrm{MHz}, \mathrm{CDCl}_{3}, 24{ }^{\circ} \mathrm{C}\right): \delta 3.88(\mathrm{~s}, 3 \mathrm{H}), 6.95(\mathrm{~d}$, $J=8.2 \mathrm{~Hz}, 2 \mathrm{H}), 8.07(\mathrm{~d}, J=8.2 \mathrm{~Hz}, 2 \mathrm{H}) .{ }^{13} \mathrm{C}\left\{{ }^{1} \mathrm{H}\right\} \mathrm{NMR}\left(101 \mathrm{MHz}, \mathrm{CDCl}_{3}, 24{ }^{\circ} \mathrm{C}\right): \delta 55.5,113.8$, 121.7, 132.4, 164.1, 171.5. All the resonances of ${ }^{1} \mathrm{H}$ and ${ }^{13} \mathrm{C}$ NMR spectra were consistent with the reported values. ${ }^{6}$

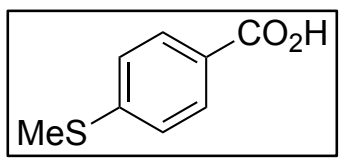

4-(Methylthio)benzoic acid (5f): The reaction of 4-fluorothioanisole (3f, 71 $\mathrm{mg}, 0.50 \mathrm{mmol})$ at $-30{ }^{\circ} \mathrm{C}$ was followed by being stirred under atmospheric pressure of $\mathrm{CO}_{2}$ at room temperature for $30 \mathrm{~min}$. To the mixture, $3 \mathrm{M} \mathrm{HCl}$ aq. $(2.0 \mathrm{~mL})$ was added. The mixture was extracted with EtOAc and combined organic layers were washed with $\mathrm{H}_{2} \mathrm{O}$. All of the volatiles were removed by rotary evaporator. After MPLC purification ( $25 \mathrm{~g}$ of silica gel, $n$-hexane:EtOAc $=2: 3$ ), the title compound $(67 \mathrm{mg}, 0.40 \mathrm{mmol}, 79 \%$ ) was obtained as a pale yellow solid. $\mathrm{R}_{\mathrm{f}} 0.44$ ( $n$-hexane/EtOAc $\left.=3: 4\right)$. Yield of 4,4'-Bis(methylthio)-1,1'-biphenyl 
was estimated in $8 \%$ yield by ${ }^{1} \mathrm{H}$ NMR spectroscopy with 1,3,5-trimethoxybenzene $(6.1 \mathrm{mg}, 36 \mu \mathrm{mol})$ as an internal standard. 5f: ${ }^{1} \mathrm{H} \mathrm{NMR}\left(400 \mathrm{MHz}, \mathrm{CDCl}_{3}, 24^{\circ} \mathrm{C}\right): \delta 2.53(\mathrm{~s}, 3 \mathrm{H}), 7.28(\mathrm{~d}, J=7.8 \mathrm{~Hz}$, $2 \mathrm{H}), 8.01(\mathrm{~d}, J=7.8 \mathrm{~Hz}, 2 \mathrm{H}) .{ }^{13} \mathrm{C}\left\{{ }^{1} \mathrm{H}\right\} \operatorname{NMR}\left(101 \mathrm{MHz}, \mathrm{CDCl}_{3}, 24{ }^{\circ} \mathrm{C}\right): \delta 14.8,124.9,125.2,130.5$, 146.8, 171.4. ${ }^{8 \mathrm{a}} \mathbf{4 , 4} \mathbf{4}^{\prime}$-Bis(methylthio)-1,1'-biphenyl: ${ }^{1} \mathrm{H}$ NMR (400 MHz, $\mathrm{CDCl}_{3}, 24{ }^{\circ} \mathrm{C}$ ): $\delta 2.52$ (s, $6 \mathrm{H}), 7.32(\mathrm{~d}, J=7.3 \mathrm{~Hz}, 4 \mathrm{H}), 7.50(\mathrm{~d}, J=7.3 \mathrm{~Hz}, 4 \mathrm{H}) .{ }^{13} \mathrm{C}\left\{{ }^{1} \mathrm{H}\right\} \mathrm{NMR}\left(101 \mathrm{MHz}, \mathrm{CDCl}_{3}, 24{ }^{\circ} \mathrm{C}\right): \delta$ 15.9, 127.0, 127.1, 137.3, 137.5. ${ }^{8 \mathrm{~b}}$ All the resonances of ${ }^{1} \mathrm{H}$ and ${ }^{13} \mathrm{C}$ NMR spectra were consistent with the reported values. ${ }^{8}$

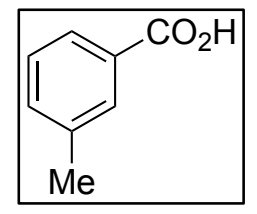

$\boldsymbol{m}$-Toluic acid (5g): The reaction of 3 -fluorotoluene $(\mathbf{3 g}, 55 \mathrm{mg}, 0.50 \mathrm{mmol})$ at $-30{ }^{\circ} \mathrm{C}$ was followed by being stirred under atmospheric pressure of $\mathrm{CO}_{2}$ at room temperature for $30 \mathrm{~min}$. To the mixture, $3 \mathrm{M} \mathrm{HCl}$ aq. $(2.0 \mathrm{~mL})$ was added. The mixture was extracted with EtOAc and combined organic layers were washed with $\mathrm{H}_{2} \mathrm{O}$. All of the volatiles were removed by rotary evaporator. After MPLC purification (Biotage ${ }^{\circledR}$ SNAP Ultra $25 \mathrm{~g}$, $n$-hexane:EtOAc $=2: 3)$, the title compound $(61 \mathrm{mg}, 0.45 \mathrm{mmol}, 90 \%)$ was obtained as a white solid. $\mathrm{R}_{\mathrm{f}} 0.56$ (n-hexane/EtOAc = 3:4). ${ }^{1} \mathrm{H}$ NMR $\left(400 \mathrm{MHz}, \mathrm{CDCl}_{3}, 24{ }^{\circ} \mathrm{C}\right): \delta 2.43(\mathrm{~s}, 3 \mathrm{H}), 7.37(\mathrm{t}, J=7.8$ $\mathrm{Hz}, 1 \mathrm{H}), 7.43(\mathrm{~d}, J=7.3 \mathrm{~Hz}, 1 \mathrm{H}), 7.93(\mathrm{~d}, J=8.3 \mathrm{~Hz}, 1 \mathrm{H}), 7.94(\mathrm{~s}, 1 \mathrm{H}) .{ }^{13} \mathrm{C}\left\{{ }^{1} \mathrm{H}\right\} \mathrm{NMR}(101 \mathrm{MHz}$, $\left.\mathrm{CDCl}_{3}, 24^{\circ} \mathrm{C}\right): \delta 21.3,127.4,128.4,129.2,130.7,134.6,138.3,172.1$. All the resonances of ${ }^{1} \mathrm{H}$ and ${ }^{13} \mathrm{C}$ NMR spectra were consistent with the reported values. ${ }^{6}$

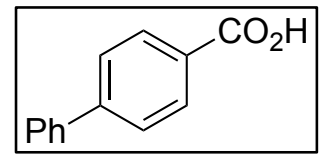

4-Phenylbenzoic acid (5h): The reaction of 4-fluorobiphenyl (3h, $86 \mathrm{mg}, 0.50$ mmol) at $-30{ }^{\circ} \mathrm{C}$ was followed by being stirred under atmospheric pressure of $\mathrm{CO}_{2}$ at room temperature for $30 \mathrm{~min}$. To the mixture, $3 \mathrm{M} \mathrm{HCl}$ aq. $(2.0 \mathrm{~mL})$ was added. The mixture was extracted with EtOAc $(40 \mathrm{~mL})$ due to low solubility of $\mathbf{5 h}$ and combined organic layers were washed with $\mathrm{H}_{2} \mathrm{O}$. All of the volatiles were removed by rotary evaporator. Purification of the crude mixture by MPLC ( $25 \mathrm{~g}$ of silica gel, $n$-hexane:EtOAc $=3: 4)$ gave the title compound (82 mg, $0.41 \mathrm{mmol}, 83 \%$ ) as a white solid. $\mathrm{R}_{\mathrm{f}} 0.37$ ( $n$-hexane/EtOAc $\left.=3: 4\right)$. Biphenyl was also isolated in $11 \%$ yield. $5 \mathbf{h}:{ }^{1} \mathrm{H}$ NMR $\left(400 \mathrm{MHz},\left(\mathrm{CD}_{3}\right)_{2} \mathrm{SO}, 24{ }^{\circ} \mathrm{C}\right): \delta 7.41(\mathrm{t}, J=6.6 \mathrm{~Hz}, 1 \mathrm{H})$, 7.49 (t, $J=7.1 \mathrm{~Hz}, 2 \mathrm{H}), 7.72(\mathrm{~d}, J=7.3 \mathrm{~Hz}, 2 \mathrm{H}), 7.79$ (d, $J=7.3 \mathrm{~Hz}, 2 \mathrm{H}), 8.02(\mathrm{~d}, J=7.8 \mathrm{~Hz}, 2 \mathrm{H})$. ${ }^{13} \mathrm{C}\left\{{ }^{1} \mathrm{H}\right\} \mathrm{NMR}\left(101 \mathrm{MHz},\left(\mathrm{CD}_{3}\right)_{2} \mathrm{SO}, 24^{\circ} \mathrm{C}\right): \delta 126.8,127.0,128.3,129.1,129.6,130.0,139.0,144.3$, 167.1. ${ }^{9 \mathrm{a}}$ Biphenyl: ${ }^{1} \mathrm{H}$ NMR (400 MHz, $\left.\mathrm{CDCl}_{3}, 24{ }^{\circ} \mathrm{C}\right): \delta 7.37$ (t, $\left.J=7.1 \mathrm{~Hz}, 2 \mathrm{H}\right), 7.47$ (t, $J=7.3$ $\mathrm{Hz}, 4 \mathrm{H}), 7.62$ (d, $J=7.8 \mathrm{~Hz}, 4 \mathrm{H}) .{ }^{13} \mathrm{C}\left\{{ }^{1} \mathrm{H}\right\} \mathrm{NMR}\left(101 \mathrm{MHz}, \mathrm{CDCl}_{3}, 24{ }^{\circ} \mathrm{C}\right): \delta 127.15,127.23,128.7$, 141.2. ${ }^{9 b}$ All the resonances of ${ }^{1} \mathrm{H}$ and ${ }^{13} \mathrm{C}$ NMR spectra were consistent with the reported values. ${ }^{9}$

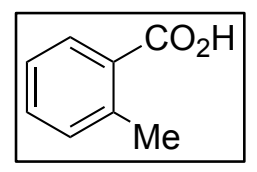

$\boldsymbol{o}$-Toluic acid (5i): The reaction of 2-fluorotoluene (3i, $55 \mathrm{mg}, 0.50 \mathrm{mmol})$ at room temperature was followed by being stirred under atmospheric pressure of $\mathrm{CO}_{2}$ at room temperature for $30 \mathrm{~min}$. To the mixture, $3 \mathrm{M} \mathrm{HCl} \mathrm{aq.}(2.0 \mathrm{~mL})$ was added. The mixture was extracted with EtOAc and combined organic layers were washed with $\mathrm{H}_{2} \mathrm{O}$. All of the volatiles were removed by rotary evaporator. After MPLC purification (Biotage ${ }^{\circledR}$ SNAP Ultra $25 \mathrm{~g}, n$ hexane:EtOAc $=2: 3)$, the title compound $(62 \mathrm{mg}, 0.46 \mathrm{mmol}, 92 \%)$ was obtained as a white solid. $\mathrm{R}_{\mathrm{f}}$ $0.56(n$-hexane/EtOAc $=3: 4) .{ }^{1} \mathrm{H}$ NMR $\left(400 \mathrm{MHz}, \mathrm{CDCl}_{3}, 24{ }^{\circ} \mathrm{C}\right): \delta 2.64(\mathrm{~s}, 3 \mathrm{H}), 7.23-7.28(\mathrm{~m}, 2 \mathrm{H})$, 
$7.43(\mathrm{t}, J=7.3 \mathrm{~Hz}, 1 \mathrm{H}), 8.05(\mathrm{~d}, J=7.3 \mathrm{~Hz}, 1 \mathrm{H}), 12.03$ (br s, $1 \mathrm{H}) .{ }^{13} \mathrm{C}\left\{{ }^{1} \mathrm{H}\right\} \mathrm{NMR}\left(101 \mathrm{MHz}, \mathrm{CDCl}_{3}\right.$, $\left.24{ }^{\circ} \mathrm{C}\right): \delta 22.1,125.9,128.3,131.6,131.9,132.9,141.4,172.9$. All the resonances of ${ }^{1} \mathrm{H}$ and ${ }^{13} \mathrm{C}$ NMR spectra were consistent with the reported values. ${ }^{6}$

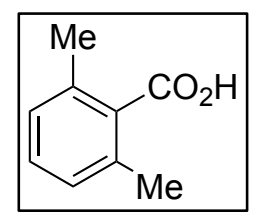

2,6-Dimethylbenzoic acid (5j): The reaction of 2-fluoro-1,3-dimethylbenzene (3j, $62 \mathrm{mg}, 0.50 \mathrm{mmol}$ ) at $50{ }^{\circ} \mathrm{C}$ was followed by being stirred under atmospheric pressure of $\mathrm{CO}_{2}$ at room temperature for $30 \mathrm{~min}$. To the mixture, $3 \mathrm{M} \mathrm{HCl}$ aq. $(2.0 \mathrm{~mL})$ was added. The mixture was extracted with EtOAc and combined organic layers were washed with $\mathrm{H}_{2} \mathrm{O}$. All of the volatiles were removed by rotary evaporator. After MPLC purification (Biotage ${ }^{\circledR}$ Sfär Silica High Capacity Duo $20 \mu \mathrm{m}, 25 \mathrm{~g}, n$-hexane:EtOAc = 2:3), the title compound (36 mg, $0.24 \mathrm{mmol}, 48 \%$ ) was obtained as a white solid. $\mathrm{R}_{\mathrm{f}} 0.44$ ( $n$-hexane/EtOAc $\left.=3: 4\right) .{ }^{1} \mathrm{H}$ NMR $\left(400 \mathrm{MHz}, \mathrm{CDCl}_{3}, 24^{\circ} \mathrm{C}\right): \delta 2.46,(\mathrm{~s}, 6 \mathrm{H}), 7.08(\mathrm{~d}, J=7.8 \mathrm{~Hz}, 2 \mathrm{H}), 7.24(\mathrm{t}, J=8.0 \mathrm{~Hz}, 1 \mathrm{H}), 11.13$ (br s, $1 \mathrm{H}) .{ }^{13} \mathrm{C}\left\{{ }^{1} \mathrm{H}\right\}$ NMR (101 MHz, $\left.\mathrm{CDCl}_{3}, 24{ }^{\circ} \mathrm{C}\right): \delta 20.1,127.9,129.9,132.3,135.6$, 175.5. All the resonances of ${ }^{1} \mathrm{H}$ and ${ }^{13} \mathrm{C}$ NMR spectra were consistent with the reported values. ${ }^{10}$

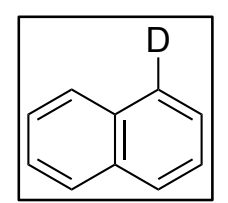

Naphthalene-1-d (5k): The reaction of 1-fluoronaphthalene (3b, $73 \mathrm{mg}, 0.50 \mathrm{mmol})$ at room temperature was followed by addition of deuterium oxide $(2.0 \mathrm{~g}, 100 \mathrm{mmol})$. Purification of the crude mixture by MPLC ( $25 \mathrm{~g}$ of silica gel, $n$-hexane) gave the title compound (64 mg, $0.50 \mathrm{mmol}, 99 \%$ ) as a white solid. $\mathrm{R}_{\mathrm{f}} 0.70$ ( $n$-hexane). ${ }^{1} \mathrm{H}$ NMR $\left(400 \mathrm{MHz}, \mathrm{CDCl}_{3}, 24^{\circ} \mathrm{C}\right): \delta 7.50(\mathrm{~d}, J=4.6 \mathrm{~Hz}, 4 \mathrm{H}), 7.87(\mathrm{t}, J=3.9 \mathrm{~Hz}, 3 \mathrm{H}) .{ }^{2} \mathrm{H} \mathrm{NMR}(61 \mathrm{MHz}$, $\left.\mathrm{CDCl}_{3}, 24{ }^{\circ} \mathrm{C}\right): \delta 7.86(\mathrm{~s}) .{ }^{13} \mathrm{C}\left\{{ }^{1} \mathrm{H}\right\} \mathrm{NMR}\left(101 \mathrm{MHz}, \mathrm{CDCl}_{3}, 24{ }^{\circ} \mathrm{C}\right): \delta 125.7,125.8,127.5(\mathrm{t}, J=$ $26.0 \mathrm{~Hz}), 127.9,127.9,127.9,133.4,133.5$. All the resonances of ${ }^{1} \mathrm{H}$ and ${ }^{13} \mathrm{C}$ NMR spectra were consistent with the reported values. ${ }^{11}$

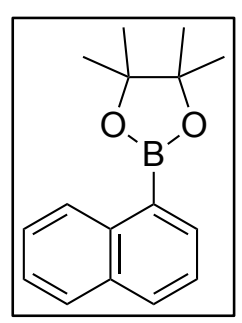

4,4,5,5-Tetramethyl-2-(naphthalen-1-yl)-1,3,2-dioxaborolane (5I): The reaction of 1-fluoronaphthalene $(\mathbf{3 b}, 73 \mathrm{mg}, 0.50 \mathrm{mmol})$ in the presence of triisopropyl borate (141 $\mathrm{mg}, 0.75 \mathrm{mmol}$ ) at room temperature was followed by addition of $3 \mathrm{M} \mathrm{HCl} \mathrm{aq.}$ $(2.0 \mathrm{~mL})$. The mixture was extracted with EtOAc and combined organic layers were washed with $\mathrm{H}_{2} \mathrm{O}$. All of the volatiles were removed by rotary evaporator. A $15 \mathrm{~mL}$ vial with a stirring bar was charged with the resulting mixture, pinacol (65 mg, 0.55 $\mathrm{mmol})$, and $n$-hexane $(10 \mathrm{~mL})$, and the resulting mixture was stirred for $24 \mathrm{~h}$ at room temperature. After evaporation of volatiles, purification of the crude mixture by MPLC (Biotage ${ }^{\circledR}$ Sfär Silica High Capacity Duo $20 \mu \mathrm{m}, 25 \mathrm{~g}, n$-hexane:EtOAc $=5: 1)$ gave the title compound ( $85 \mathrm{mg}, 0.34 \mathrm{mmol}$, $67 \%$ ) as a white solid. $\mathrm{R}_{\mathrm{f}} 0.49$ ( $n$-hexane/EtOAc $\left.=5: 1\right) .{ }^{1} \mathrm{H}$ NMR $\left(400 \mathrm{MHz}, \mathrm{CDCl}_{3}, 24{ }^{\circ} \mathrm{C}\right): \delta 1.45$ $(\mathrm{s}, 12 \mathrm{H}), 7.50$ (t, $J=7.3 \mathrm{~Hz}, 2 \mathrm{H}), 7.57$ (t, $J=7.6 \mathrm{~Hz}, 1 \mathrm{H}), 7.86(\mathrm{~d}, J=7.8 \mathrm{~Hz}, 1 \mathrm{H}), 7.96(\mathrm{~d}, J=7.8$ $\mathrm{Hz}, 1 \mathrm{H}), 8.12(\mathrm{~d}, J=6.4 \mathrm{~Hz}, 1 \mathrm{H}), 8.81(\mathrm{~d}, J=8.2 \mathrm{~Hz}, 1 \mathrm{H}) .{ }^{13} \mathrm{C}\left\{{ }^{1} \mathrm{H}\right\} \mathrm{NMR}\left(101 \mathrm{MHz}, \mathrm{CDCl}_{3}, 24{ }^{\circ} \mathrm{C}\right)$ : $\delta 24.9,83.7,124.9,125.4,126.3,128.3,128.4,131.6,133.2,135.6,136.9$, the carbon directly attached to the boron atom was not detected due to quadrupolar relaxation. ${ }^{11} \mathrm{~B}\left\{{ }^{1} \mathrm{H}\right\} \mathrm{NMR}\left(128 \mathrm{MHz}, \mathrm{CDCl}_{3}\right.$, $24{ }^{\circ} \mathrm{C}$ ): $\delta 30.7$. All the resonances of ${ }^{1} \mathrm{H},{ }^{11} \mathrm{~B}$ and ${ }^{13} \mathrm{C}$ NMR spectra were consistent with the reported values. $^{12}$ 


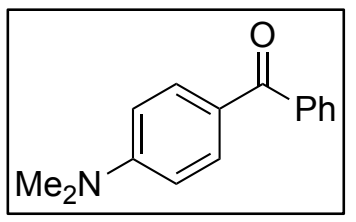

4-Dimethylaminobenzophenone $(\mathbf{5 m})$ : The reaction of 1-fluoro-4-dimethylaminobenzene $(3 \mathbf{k}, 70 \mathrm{mg}, 0.50 \mathrm{mmol})$ at $50{ }^{\circ} \mathrm{C}$ was followed by addition of $N$-methoxy- $N$-methylbenzamide $(165 \mathrm{mg}, 1.0 \mathrm{mmol})$. After being stirred at room temperature for $3 \mathrm{~h}$, purification of the mixture by MPLC (Biotage ${ }^{\circledR}$ Sfär Silica High Capacity Duo $20 \mu \mathrm{m}, 25 \mathrm{~g}, n$-hexane:EtOAc = 5:1) gave the title compound (25 mg, 0.11 mmol, $22 \%$ ) as a yellow solid. $\mathrm{R}_{\mathrm{f}} 0.29(n$-hexane/EtOAc $=9: 1) .{ }^{1} \mathrm{H} \mathrm{NMR}\left(400 \mathrm{MHz}, \mathrm{CDCl}_{3}, 24{ }^{\circ} \mathrm{C}\right)$ : $\delta 3.07(\mathrm{~s}, 6 \mathrm{H}), 6.68(\mathrm{~d}, J=7.8 \mathrm{~Hz}, 2 \mathrm{H}), 7.45(\mathrm{t}, J=7.3 \mathrm{~Hz}, 2 \mathrm{H}), 7.52(\mathrm{t}, J=7.3 \mathrm{~Hz}, 1 \mathrm{H}), 7.73(\mathrm{~d}, J$ $=7.8 \mathrm{~Hz}, 2 \mathrm{H}), 7.81(\mathrm{~d}, J=8.2 \mathrm{~Hz}, 2 \mathrm{H}) .{ }^{13} \mathrm{C}\left\{{ }^{1} \mathrm{H}\right\} \mathrm{NMR}\left(101 \mathrm{MHz}, \mathrm{CDCl}_{3}, 24{ }^{\circ} \mathrm{C}\right): \delta 40.0,110.5$, $124.8,128.0,129.4,131.1,132.7,139.3,153.3,195.1$. All the resonances of ${ }^{1} \mathrm{H}$ and ${ }^{13} \mathrm{C}$ NMR spectra were consistent with the reported values. ${ }^{13}$

\section{Gram-scale synthesis}

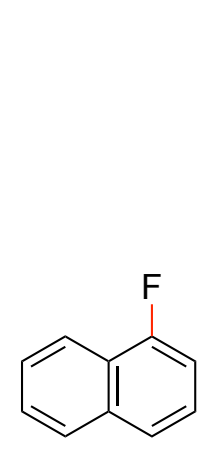

3b, $10 \mathrm{mmol}$
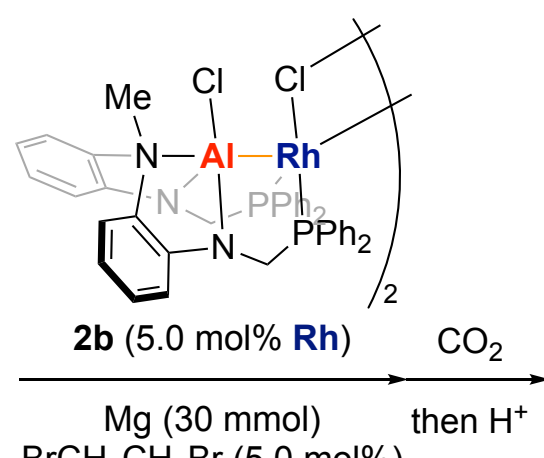

$\mathrm{BrCH}_{2} \mathrm{CH}_{2} \mathrm{Br}(5.0 \mathrm{~mol} \%)$

THF, r.t., $22 \mathrm{~h}$<smiles>O=C(O)c1cccc2ccccc12</smiles>

$5 a$

$82 \%, 1.41 \mathrm{~g}$

In a glove box, a $80 \mathrm{~mL}$ Schlenk tube with a stirring bar was charged with magnesium powder (730 $\mathrm{mg}, 30 \mathrm{mmol})$, THF (5.0 mL), and 1,2-dibromoethane (94 mg, $0.5 \mathrm{mmol})$, and the resulting mixture was stirred for $20 \mathrm{~min}$ at room temperature. $\mathbf{3 b}(10 \mathrm{mmol}), \mathbf{2 b}(404 \mathrm{mg}, 0.25 \mathrm{mmol})$, and THF (15 $\mathrm{mL}$ ) were put into the Schlenk tube. The Schlenk tube was taken out of the glove box and the mixture was stirred for $22 \mathrm{~h}$ at room temperature and then, stirred under atmospheric pressure of $\mathrm{CO}_{2}$ at room temperature for $30 \mathrm{~min}$. To the mixture was added $3 \mathrm{M} \mathrm{HCl}$ aq. $(20 \mathrm{~mL})$. The mixture was extracted with EtOAc and combined organic layers were washed with $\mathrm{H}_{2} \mathrm{O}$. All of the volatiles were removed by rotary evaporator. The mixture was extracted with EtOAc and combined organic layers were washed with $\mathrm{H}_{2} \mathrm{O}$. All of the volatiles were removed by rotary evaporator. After MPLC purification (40 $\mathrm{g}$ of silica gel, $n$-hexane: $\mathrm{CH}_{2} \mathrm{Cl}_{2}=1: 2$ then $n$-hexane:EtOAc $\left.=3: 4\right)$, the title compound $(1.4 \mathrm{~g}$, $8.2 \mathrm{mmol}, 82 \%)$ was obtained as a white solid. $\mathrm{R}_{\mathrm{f}} 0.59(n$-hexane/EtOAc $=3: 4)$. 


\section{General procedures for $\mathrm{Eq} 1$.}

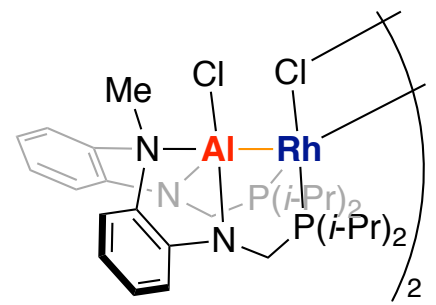

$2 \mathrm{a}, 30 \mu \mathrm{mol}$

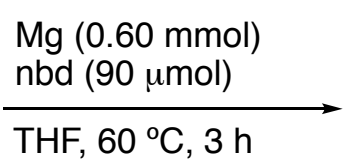

$\mathrm{THF}, 60^{\circ} \mathrm{C}, 3 \mathrm{~h}$

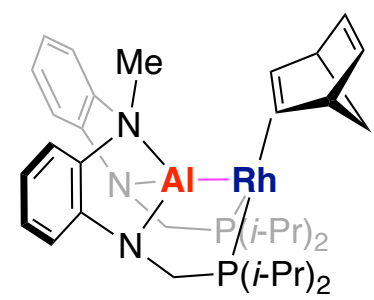

1a-nbd, $83 \%$

In a glove box, a $4 \mathrm{~mL}$ vial with a stirring bar was charged with $\mathbf{2 a}(40 \mathrm{mg}, 30 \mu \mathrm{mol})$, magnesium powder (15 mg, $0.60 \mathrm{mmol})$, 2,5-norbornadiene (nbd, $8.3 \mathrm{mg}, 90 \mu \mathrm{mol})$, and THF $(1.0 \mathrm{~mL}$ ) and the resulting mixture was stirred for $3 \mathrm{~h}$ at $60{ }^{\circ} \mathrm{C}$. After filtration through a KIRIYAMA filter paper (No. 5A), the filtrate was concentrated to afford a brown precipitate. The precipitate was analyzed by ${ }^{1} \mathrm{H}$ and ${ }^{31} \mathrm{P}$ NMR spectroscopies. Spectroscopic data for 1a-nbd match those previously reported in the literature. ${ }^{1}$

\section{General procedures for $\mathrm{Eq} 2$.}

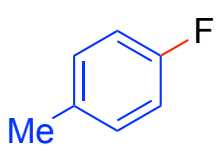

$3 c, 0.25 \mathrm{mmol}$
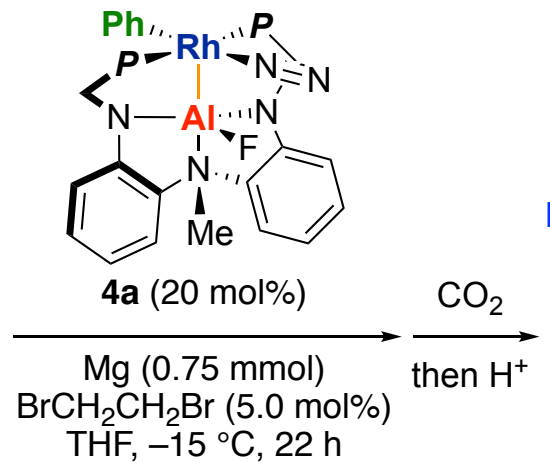

$\mathrm{BrCH}_{2} \mathrm{CH}_{2} \mathrm{Br}(5.0 \mathrm{~mol} \%)$

THF, $-15^{\circ} \mathrm{C}, 22 \mathrm{~h}$<smiles>Cc1ccc(C(=O)O)cc1</smiles>

5 c, $70 \%$

based on 3c<smiles>O=C(O)c1ccccc1</smiles>

$5 b, 48 \%$

based on $4 a$

In a glove box, a $4 \mathrm{~mL}$ vial with a stirring bar was charged with magnesium powder (18 $\mathrm{mg}, 0.75$ $\mathrm{mmol})$, THF $(500 \mu \mathrm{L})$, and 1,2-dibromoethane $(2.3 \mathrm{mg}, 13 \mu \mathrm{mol})$ and the resulting mixture was stirred for $20 \mathrm{~min}$ at room temperature. $3 \mathbf{c}(28 \mathrm{mg}, 0.25 \mathrm{mmol}), 4 \mathbf{a}(36 \mathrm{mg}, 50 \mu \mathrm{mol})$, and THF (500 $\mu \mathrm{L})$ were put into the vial. The mixture was stirred for $22 \mathrm{~h}$ at $-15^{\circ} \mathrm{C}$. The resulting mixture was stirred under $\mathrm{CO}_{2}(1 \mathrm{~atm})$ at room temperature for $30 \mathrm{~min}$. To the mixture was added $3 \mathrm{M} \mathrm{HCl}(1.5$ $\mathrm{mL}$ ). The mixture was extracted with EtOAc and combined organic layers were washed with $\mathrm{H}_{2} \mathrm{O}$. All of the volatiles were removed by rotary evaporator. The crude mixture was analyzed by ${ }^{1} \mathrm{H}$ NMR spectroscopy with 1,3,5-trimethoxybenzene $(13 \mathrm{mg}, 76 \mu \mathrm{mol})$ as an internal standard. According to the ${ }^{1} \mathrm{H}$ NMR spectrum, yields of $p$-toluic acid (5c) and benzoic acid (5b) were estimated in $70 \%$ yield $(0.18 \mathrm{mmol})$ based on $\mathbf{3 c}$ and $48 \%$ yield $(24 \mu \mathrm{mol})$ based on $\mathbf{4 a}$, respectively. 
Carbon-fluorine bond activation at $-30^{\circ} \mathrm{C}$ (Eq S1).

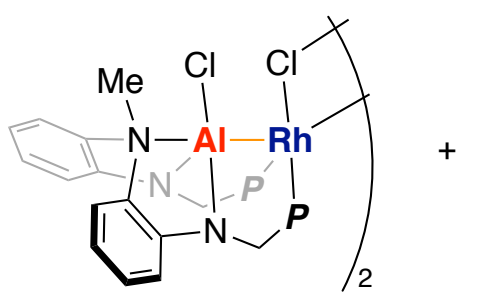

2a, 50 umol

$\boldsymbol{P}=\mathrm{P}(i-\mathrm{Pr})_{2}$

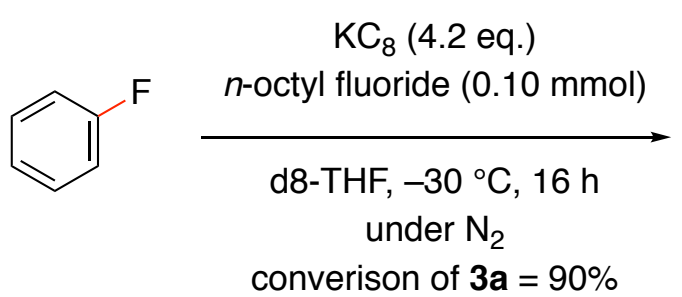

$3 a, 0.10 \mathrm{mmol}$

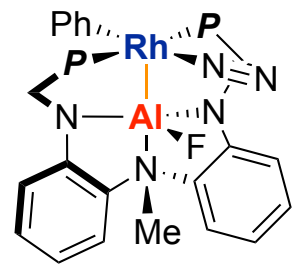

To a d8-THF (1.0 mL) solution of $\mathbf{2 a}(71 \mathrm{mg}, 50 \mu \mathrm{mol})$ and fluorobenzene (3a, $10 \mathrm{mg}, 0.10 \mathrm{mmol})$, a suspension of potassium graphite $(28 \mathrm{mg}, 0.21 \mathrm{mmol})$ in $\mathrm{d} 8$-THF $(2.0 \mathrm{~mL})$ was slowly added at $78^{\circ} \mathrm{C}$. After the reaction mixture was stirred at $-30{ }^{\circ} \mathrm{C}$ for $16 \mathrm{~h},{ }^{19} \mathrm{~F}$ NMR spectroscopy of the resulting mixture was measured at $-30^{\circ} \mathrm{C}$. Formation of $\mathbf{4 a}$ was not confirmed by ${ }^{19} \mathrm{~F}$ NMR spectroscopy at $30{ }^{\circ} \mathrm{C}$ because of broadness of the signal of $\mathbf{4 a}$ at $-30{ }^{\circ} \mathrm{C}$. However, we concluded that cooperative activation of the $\mathrm{C}-\mathrm{F}$ bond of $\mathbf{3 a}$ by in situ generated $1 \mathbf{a}$ occurred at $-30{ }^{\circ} \mathrm{C}$ based on the results as follows: 1) When the same sample was measured at room temperature, 4a was clearly observed (Figure S5). 2) The conversion of 3a at $-30{ }^{\circ} \mathrm{C}$ was estimated in $90 \%$ by ${ }^{19} \mathrm{~F}$ NMR spectroscopy with $n$-octyl fluoride (13 mg, $0.10 \mathrm{mmol}$ ) as an internal standard (Figure S6). 3) The catalytic magnesiation of 3a proceeded at $-30^{\circ} \mathrm{C}$.

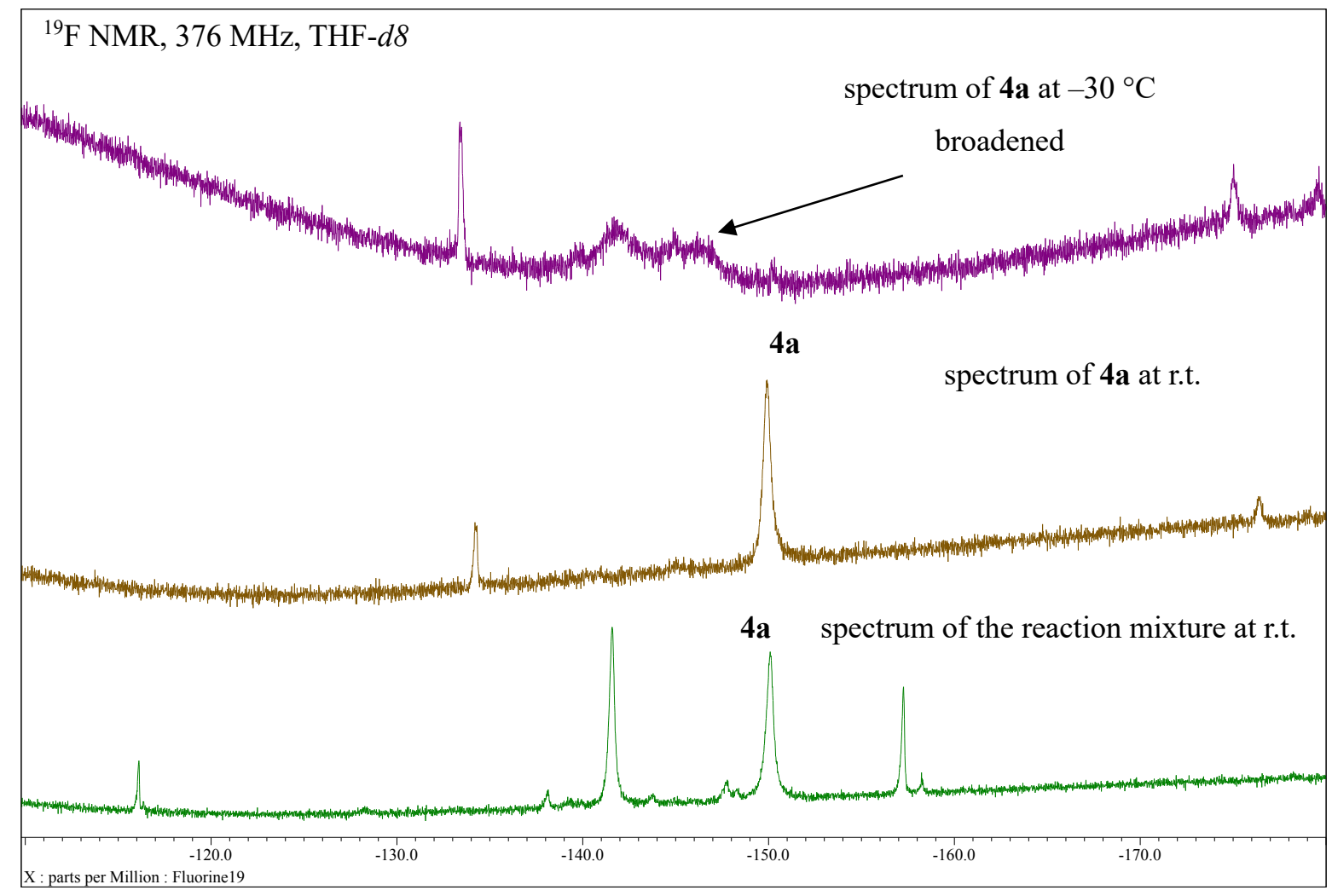

Figure S5. ${ }^{19} \mathrm{~F}$ NMR spectra of the reaction mixture related to $\mathbf{S 1}$ (green: measured at $-30{ }^{\circ} \mathrm{C}$, brown: measured at room temperature) and $4 \mathbf{a}$ (blue: measured at $-30{ }^{\circ} \mathrm{C}$, purple: measured at room temperature). 


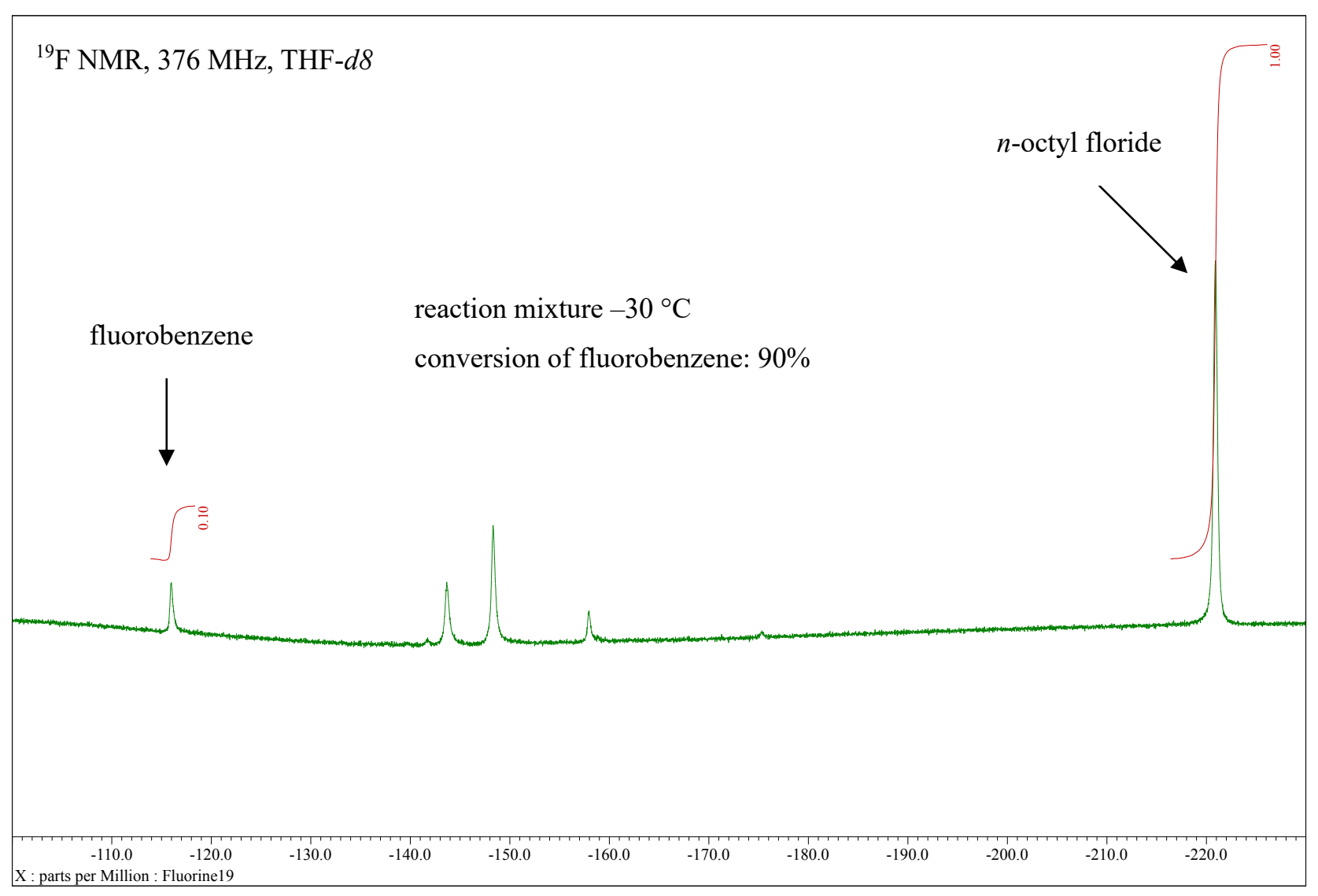

Figure S6. A ${ }^{19} \mathrm{~F}$ NMR spectrum of $\mathbf{S 1}$ with $n$-octyl fluoride as an internal standard.

Identification of the generated organomagnesium species (Eq S2).
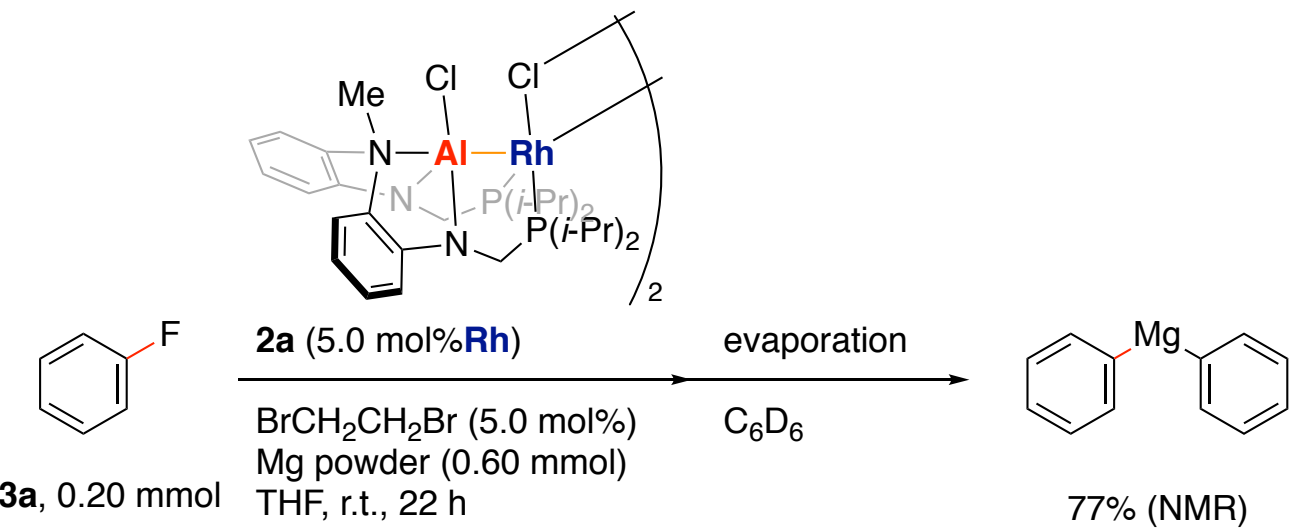

In a glove box, a $4 \mathrm{~mL}$ vial with a stirring bar was charged with magnesium powder (15 $\mathrm{mg}, 0.60$ mmol), THF $(500 \mu \mathrm{L})$, and 1,2-dibromoethane $(1.9 \mathrm{mg}, 10 \mu \mathrm{mol})$ and the resulting mixture was stirred for $20 \mathrm{~min}$ at room temperature. Fluorobenzene (3a, $19 \mathrm{mg}, 0.20 \mathrm{mmol}), \mathbf{2 a}(6.7 \mathrm{mg}, 5.0 \mu \mathrm{mol})$, and THF $(500 \mu \mathrm{L})$ were put into the vial. The mixture was stirred for $22 \mathrm{~h}$ at room temperature. All of the volatiles were removed. Internal standard (1,3,5-trimethoxybenzene, $39 \mathrm{mg}, 0.23 \mathrm{mmol})$ and $\mathrm{C}_{6} \mathrm{D}_{6}(500 \mu \mathrm{L})$ were added to the resulting mixture. According to ${ }^{1} \mathrm{H}$ and ${ }^{13} \mathrm{C}$ NMR spectra of the mixture, generation of diphenylmagnesium (77\% yield) was confirmed by comparing with ${ }^{1} \mathrm{H}$ and ${ }^{13} \mathrm{C}$ NMR spectra of independently synthesized diphenylmagnesium with $\mathbf{2 a}(5.0 \mathrm{~mol} \% \mathrm{Rh})$ or $\mathbf{4 a}(5$ 
mol\% Rh) in $\mathrm{C}_{6} \mathrm{D}_{6} \cdot{ }^{14}$ In addition, independently synthesized phenylmagnesium fluoride ${ }^{15}$ has very low solubility toward THF and $\mathrm{C}_{6} \mathrm{D}_{6}$.

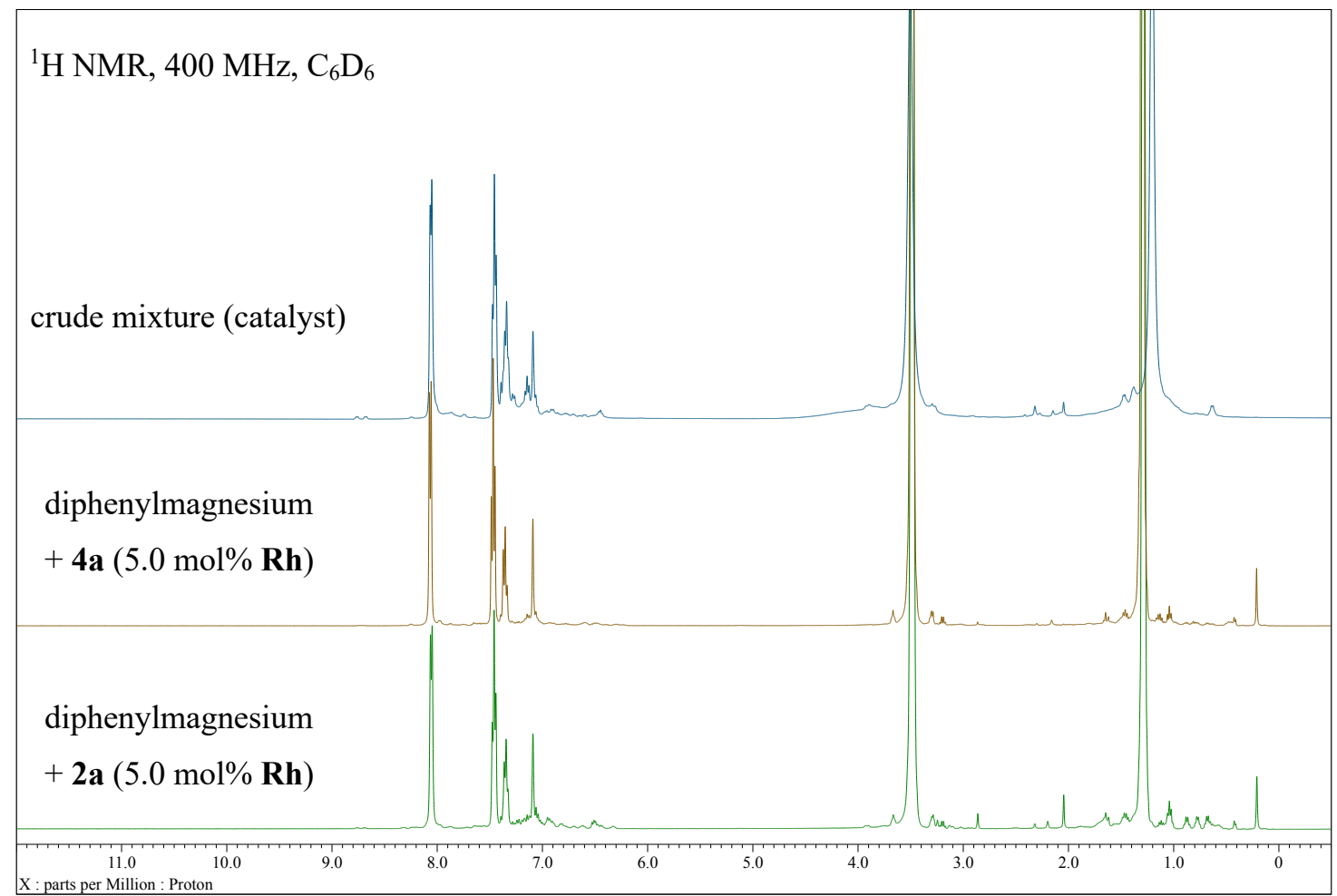

Figure S7. ${ }^{1} \mathrm{H}$ NMR spectra related to $\mathbf{S 2}$. 


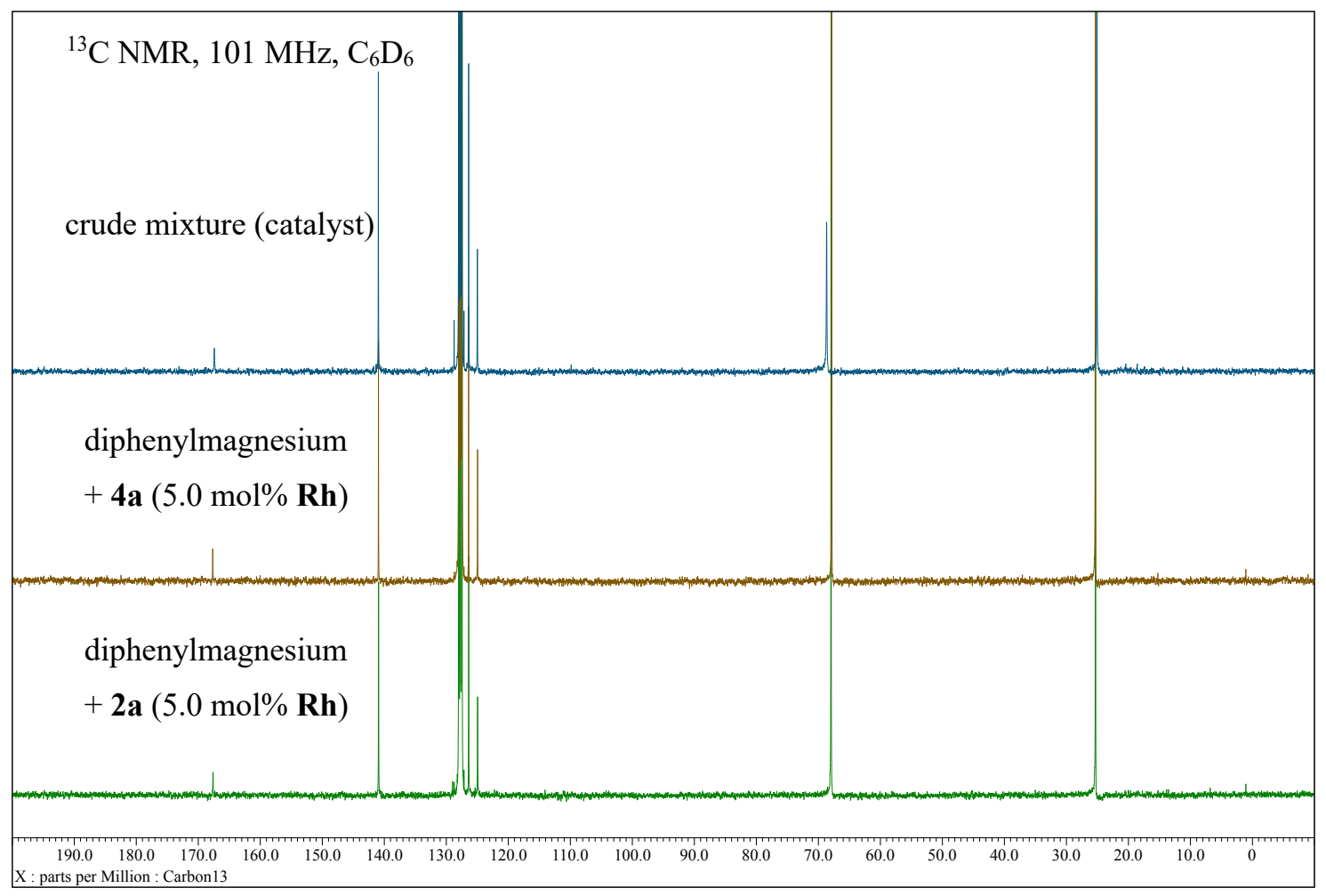

Figure S8. ${ }^{13} \mathrm{C}$ NMR spectra related to $\mathbf{S 2}$.

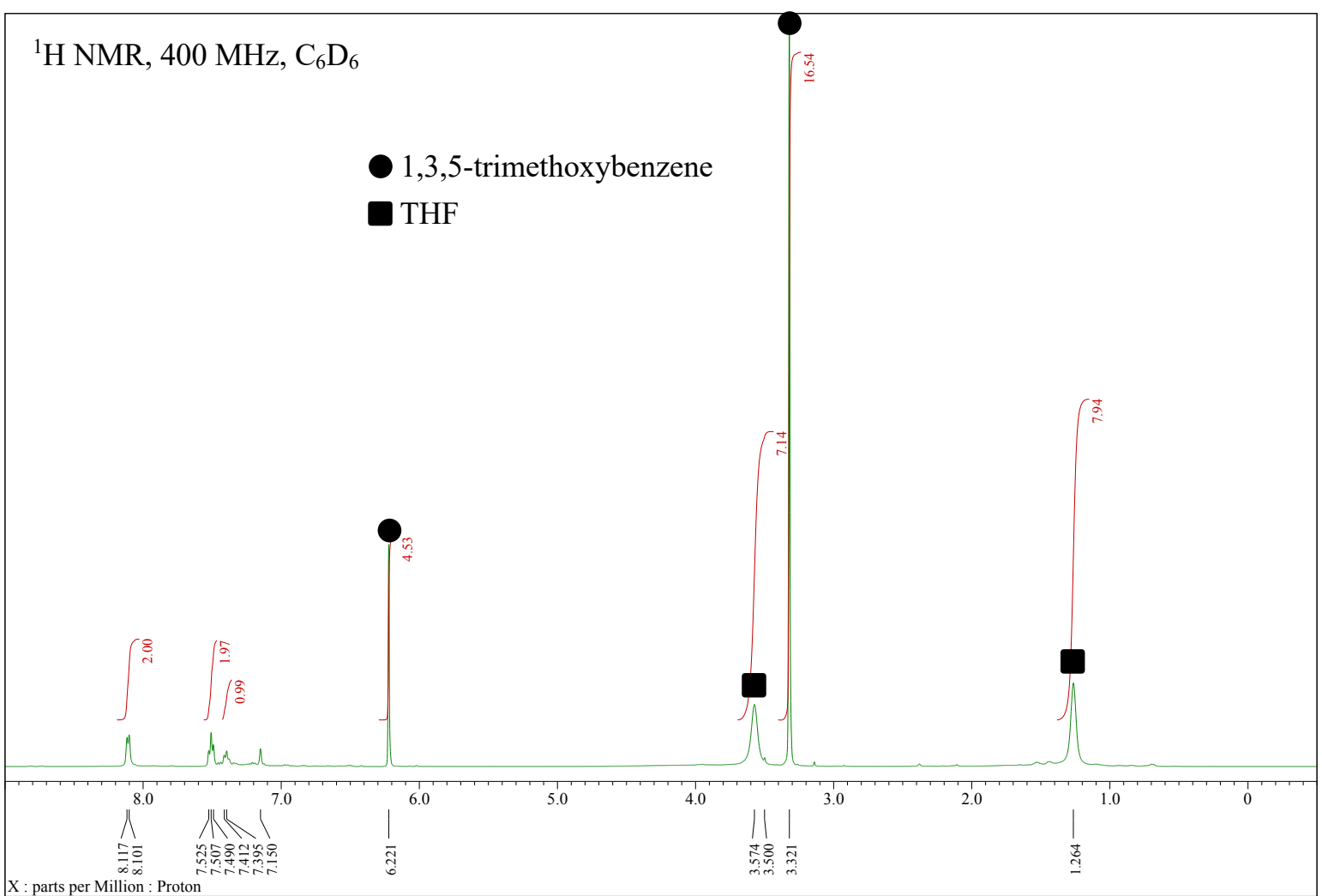

Figure S9. ${ }^{1} \mathrm{H}$ NMR spectrum of $\mathbf{S 2}$ with 1,3,5-trimethoxybenzene. 


\section{Synthesis of Al-Rh complex $2 b$.}

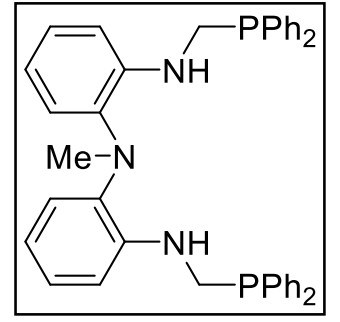

PNNNP ligand ( $\left.\mathbf{L H}_{2}\right)$ : Formaldehyde $(0.60 \mathrm{~g}, 20 \mathrm{mmol})$ and diphenylphosphine ( $3.7 \mathrm{~g}, 20 \mathrm{mmol})$ were charged in an $80 \mathrm{~mL}$ Schlenk tube and the reaction mixture was stirred for $2 \mathrm{~h}$ at $100{ }^{\circ} \mathrm{C}$. After being cooled to room temperature, to the reaction mixture was added toluene $(150 \mathrm{~mL})$ and $N$-(2-aminophenyl)- $N$ methylbenzene-1,2-diamine $(2.1 \mathrm{~g}, 10 \mathrm{mmol})$. The mixture was stirred for $16 \mathrm{~h}$ at $80{ }^{\circ} \mathrm{C}$. After cooling the solution to room temperature, it was dried over $\mathrm{MgSO}_{4}$. After filtration of $\mathrm{MgSO}_{4}$, the filtrate was concentrated under reduced pressure. Diethyl ether $(10 \mathrm{~mL} \times 2)$ was added and evaporated under reduced pressure to remove toluene. The desired product was obtained as light brown powder ( $5.5 \mathrm{~g}, 9.1 \mathrm{mmol}, 91 \%$ yield $)$. The obtained product was used in the next step without further purifications.

crude NMR data: ${ }^{1} \mathrm{H}$ NMR $\left(400 \mathrm{MHz}, \mathrm{CDCl}_{3}, 24{ }^{\circ} \mathrm{C}\right): \delta 2.67\left(\mathrm{~s}, 3 \mathrm{H}, \mathrm{NCH}_{3}\right), 3.64$ (s br, $4 \mathrm{H}, \mathrm{PCH}_{2}-$ $\mathrm{NH}), 4.37$ (s br, $\left.2 \mathrm{H}, \mathrm{PCH}_{2}-\mathrm{NH}\right), 6.66(\mathrm{~d}, J=6.9 \mathrm{~Hz}, 4 \mathrm{H}$, overlapped one doublet signal $(2 \mathrm{H})$ and one triplet signal $(2 \mathrm{H})), 6.93(\mathrm{~d}, J=7.3 \mathrm{~Hz}, 2 \mathrm{H}), 7.00(\mathrm{t}, J=7.6 \mathrm{~Hz}, 2 \mathrm{H}), 7.22-7.39(20 \mathrm{H}) .{ }^{13} \mathrm{C}\left\{{ }^{1} \mathrm{H}\right\} \mathrm{NMR}$ $\left(101 \mathrm{MHz}, \mathrm{CDCl}_{3}, 24^{\circ} \mathrm{C}\right): \delta 40.2,43.6\left(\mathrm{~d}, J_{\mathrm{P}-\mathrm{C}}=9.3 \mathrm{~Hz}\right), 110.8,117.1,121.6,125.1,128.5\left(\mathrm{~d}, J_{\mathrm{P}-\mathrm{C}}\right.$ $=6.9 \mathrm{~Hz}), 128.7,132.7\left(\mathrm{~d}, J_{\mathrm{P}-\mathrm{C}}=19 \mathrm{~Hz}\right), 136.2,136.8\left(\mathrm{~d}, J_{\mathrm{P}-\mathrm{C}}=14 \mathrm{~Hz}\right), 142.0\left(\mathrm{~d}, J_{\mathrm{P}-\mathrm{C}}=6.9 \mathrm{~Hz}\right)$. ${ }^{31} \mathrm{P}\left\{{ }^{1} \mathrm{H}\right\} \quad \mathrm{NMR} \quad\left(162 \mathrm{MHz}, \mathrm{CDCl}_{3}, 24{ }^{\circ} \mathrm{C}\right) \quad \delta-18.8$. HRMS-[ESI $\left.(+)\right] \quad(\mathrm{m} / \mathrm{z})$ : calcd for $\left[\mathrm{C}_{39} \mathrm{H}_{37} \mathrm{~N}_{3} \mathrm{P}_{2}+\mathrm{Na}\right]^{+}, 632.2353$; found, 632.2355.

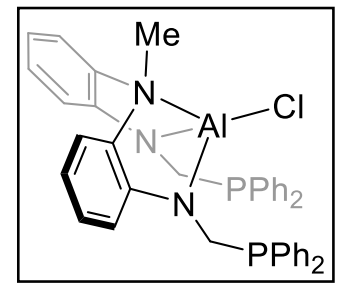

L(AICI): To a $\mathrm{Et}_{2} \mathrm{O}(60 \mathrm{~mL})$ solution of $\mathrm{LH}_{2}(12 \mathrm{~g}, 20 \mathrm{mmol})$ in an $80 \mathrm{~mL}$ Schlenk tube, a solution of $t$-BuLi in pentane $(1.53 \mathrm{M}, 27 \mathrm{~mL}, 41 \mathrm{mmol})$ was added dropwise at room temperature. The resulting solution was stirred for 15 min and then, it was added dropwise to a suspension of $\mathrm{AlCl}_{3}(2.6 \mathrm{~g}, 20 \mathrm{mmol})$ in toluene $(60 \mathrm{~mL})$ at room temperature. After stirring the reaction mixture for $3 \mathrm{~h}$ at room temperature, the solution was evaporated under reduced pressure and the target compound was extracted with toluene (ca. $200 \mathrm{~mL}$ ). The toluene solution was evaporated again under reduced pressure, and the precipitate was washed by hexane $(20 \mathrm{~mL}, 10 \mathrm{~mL} \times 2)$ to afford $\mathrm{L}(\mathrm{AlCl})$ as a gray powder $(7.0 \mathrm{~g}, 10 \mathrm{mmol}, 53 \%)$. $\mathrm{L}(\mathrm{AlCl})$ was used in next step without further purifications. crude NMR data of $\mathrm{L}(\mathrm{AlCl}) ;{ }^{1} \mathrm{H} \mathrm{NMR}\left(400 \mathrm{MHz}, \mathrm{C}_{6} \mathrm{D}_{6}, 24^{\circ} \mathrm{C}\right): \delta 2.76\left(\mathrm{~s}, 3 \mathrm{H}, \mathrm{NCH}_{3}\right), 3.49(\mathrm{~d}, J=12.8 \mathrm{~Hz}$, 2H, $\left.\mathrm{PCH}_{2}-\mathrm{NH}\right), 3.88$ (d, $\left.J=12.8 \mathrm{~Hz}, 2 \mathrm{H}, \mathrm{PCH}_{2}-\mathrm{NH}\right), 6.52$ (t, $\left.J=7.8 \mathrm{~Hz}, 2 \mathrm{H}\right), 6.58$ (d, J=7.8 Hz, 2H), 6.90-7.11 (m br, 16H), 7.37 (m br, 4H), 7.53 (m br, 4H). ${ }^{13} \mathrm{C}\left\{{ }^{1} \mathrm{H}\right\}$ NMR (101 MHz, $\mathrm{C}_{6} \mathrm{D}_{6}$, $\left.24{ }^{\circ} \mathrm{C}\right): \delta 45.7,47.1,112.1,115.5,122.2,128.7\left(\mathrm{t}, J_{\mathrm{P}-\mathrm{C}}=3.5 \mathrm{~Hz}\right), 128.8,128.9\left(\mathrm{t}, J_{\mathrm{P}-\mathrm{C}}=3.5 \mathrm{~Hz}\right)$, $129.0,129.5,132.4\left(\mathrm{t}, J_{\mathrm{P}-\mathrm{C}}=8.1 \mathrm{~Hz}\right), 134.0\left(\mathrm{t}, J_{\mathrm{P}-\mathrm{C}}=8.7 \mathrm{~Hz}\right), 136.2,136.9,137.2,149.3\left(\mathrm{t}, J_{\mathrm{P}-\mathrm{C}}=8.7\right.$ $\mathrm{Hz}) .{ }^{31} \mathrm{P}\left\{{ }^{1} \mathrm{H}\right\}$ NMR $\left(162 \mathrm{MHz}, \mathrm{C}_{6} \mathrm{D}_{6}, 24{ }^{\circ} \mathrm{C}\right) \delta-18.8$. 


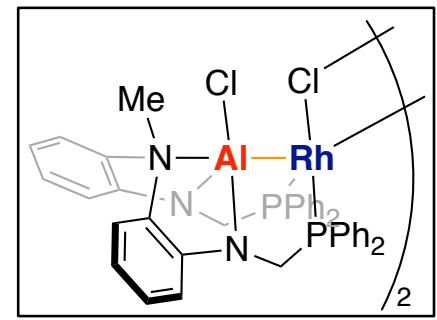

2b: To a toluene $(2.0 \mathrm{~mL})$ solution of $[\mathrm{Rh}(\mathrm{nbd})(\mu-\mathrm{Cl})]_{2}(688 \mathrm{mg}, 1.5$ $\mathrm{mmol}), \mathrm{L}(\mathrm{AlCl})(2.0 \mathrm{~g}, 3.0 \mathrm{mmol})$ in toluene $(18 \mathrm{~mL})$ was added dropwise at room temperature. The resulting deep dark-red solution was stirred at $80{ }^{\circ} \mathrm{C}$ for $16 \mathrm{~h}$ to generate dull yellow precipitates. The precipitates were collected by filtration and then, washed with toluene $(2.0 \mathrm{~mL} \times 3)$, THF $(2.0 \mathrm{~mL} \times 3)$, and pentane $(2.0 \mathrm{~mL} \times 3)$ in this order. After drying it under reduced pressure, yellow crystals $(1.5 \mathrm{~g}, 1.9 \mathrm{mmol}, 62 \%$, calculated as monomer) were obtained. m.p. $289{ }^{\circ} \mathrm{C}$ (decomp). Yellow crystals of $\mathbf{2} \mathbf{b}$, which are suitable for X-ray diffraction analysis and elemental analysis, were obtained from a saturated dichloromethane solution of $\mathbf{2 b}$ at $-35^{\circ} \mathrm{C}$. It was difficult to identify $\mathbf{2 b}$ by NMR spectroscopies completely because it showed low solubility of $\mathbf{2 b}$ toward common organic solvents and the signals from $\mathbf{2 b}$ is almost broad since it may adopt unsymmetrical forms in solution similar to the almost same complex we previously reported. ${ }^{1}$

${ }^{1} \mathrm{H}$ NMR $\left(400 \mathrm{MHz}, \mathrm{CD}_{2} \mathrm{Cl}_{2}, 24^{\circ} \mathrm{C}\right) \delta 3.29$ (br, 3H), $3.50(\mathrm{~s}, 4 \mathrm{H}), 6.18$ (br, 2H), 6.71 (br, 2H), 6.947.34 (m br, 16H), 7.40-7.92 (br, 8H). ${ }^{13} \mathrm{C}$ NMR could not be measured because of low intensity of signals at room temperature. ${ }^{31} \mathrm{P}\left\{{ }^{1} \mathrm{H}\right\} \mathrm{NMR}\left(162 \mathrm{MHz}, \mathrm{CD}_{2} \mathrm{Cl}_{2},-80{ }^{\circ} \mathrm{C}\right): \delta 48.6 / 60.0\left(J_{\mathrm{P}-\mathrm{Rh}}=\right.$ $\left.161.3 / 161.3 \mathrm{~Hz}, J_{\mathrm{P}-\mathrm{P}}=39.2 / 39.2 \mathrm{~Hz}\right), 50.9 / 58.3\left(J_{\mathrm{P}-\mathrm{Rh}}=174.4 / 170.0 \mathrm{~Hz}, J_{\mathrm{P}-\mathrm{P}}=34.9 / 34.9 \mathrm{~Hz}\right)$. Anal. Calcd $\mathrm{C}_{79} \mathrm{H}_{72} \mathrm{Cl}_{6} \mathrm{~N}_{6} \mathrm{P}_{4} \mathrm{Al}_{2} \mathrm{Rh}_{2}(\mathbf{2 b}+1.0$ dichloromethane $): \mathrm{C}, 55.75 ; \mathrm{H}, 4.26 ; \mathrm{N}, 4.94$. Found: $\mathrm{C}, 55.79$; $\mathrm{H}, 4.52 ; \mathrm{N}, 4.87$. 


\section{$X$-ray diffraction study and X-ray crystallographic analysis.}

The crystals of $\mathbf{2 b}$ and $\mathbf{4 a}$ were mounted on the CryoLoop (Hampton Research Corp.) with a layer of light mineral oil and placed in a nitrogen stream at 143(1) K. The X-ray structural determinations of 2b were performed on a Rigaku/Saturn724+ CCD diffractometers using graphite-monochromated Mo K $\alpha$ radiation $(\lambda=0.71075 \AA)$ at $153 \mathrm{~K}$, and processed using CrysAlis ${ }^{\text {Pro }}$ (Agilent). ${ }^{16}$ The X-ray structural determinations of $4 \mathbf{a}$ were performed on a Rigaku/Saturn724+ CCD diffractometers using graphite-monochromated Mo K $\alpha$ radiation $(\lambda=0.71075 \AA)$ at $153 \mathrm{~K}$, and processed using CrystalClear (Rigaku, Tokyo, Japan). ${ }^{17,18}$ The structures were solved by a direct method and refined by full-matrix least-square refinement on $F 2$. The structure of $\mathbf{2 b}$ was solved by SHELXT and refined by SHELXL. ${ }^{19,20}$ The structure of $\mathbf{4 a}$ was solved by SIR92 ${ }^{21}$ and refined by SHELXL (Version 2018/3). ${ }^{19,20}$ Non-hydrogen atoms were anisotropically refined. Hydrogen atoms were included in the refinement on calculated positions riding on their carrier atoms. The function minimized was $\left[\Sigma w\left(F_{\mathrm{o}}{ }^{2}-F_{\mathrm{c}}{ }^{2}\right)^{2}\right]\left(w=1 /\left[\sigma^{2}\left(F_{\mathrm{o}}{ }^{2}\right)+(a \mathrm{P})^{2}+b \mathrm{P}\right]\right)$, where $\mathrm{P}=\left(\operatorname{Max}\left(F_{\mathrm{o}}^{2}, 0\right)+2 F_{\mathrm{c}}^{2}\right) / 3$ with $\sigma^{2}\left(F_{\mathrm{o}}^{2}\right)$ from counting statistics. The function $R 1$ and $w R 2$ were $\left(\Sigma|| F_{\mathrm{o}}|-| F_{\mathrm{c}} \mid\right) / \Sigma\left|F_{\mathrm{o}}\right|$ and $\left[\Sigma w\left(F_{\mathrm{o}}^{2}-F_{\mathrm{c}}^{2}\right)^{2} /\right.$ $\left.\Sigma\left(w F_{\mathrm{o}}{ }^{4}\right)\right]^{1 / 2}$, respectively. CCDC 2000480 (for $\mathbf{2 b}$ ) and 1999655 (for 4a) contain the supplementary crystallographic data. These data can be obtained from The Cambridge Crystallographic Data Centre. A B alert in the CIF file of 4 a could not be solved because crystals require a long exposure time due to their low crystallinity. 


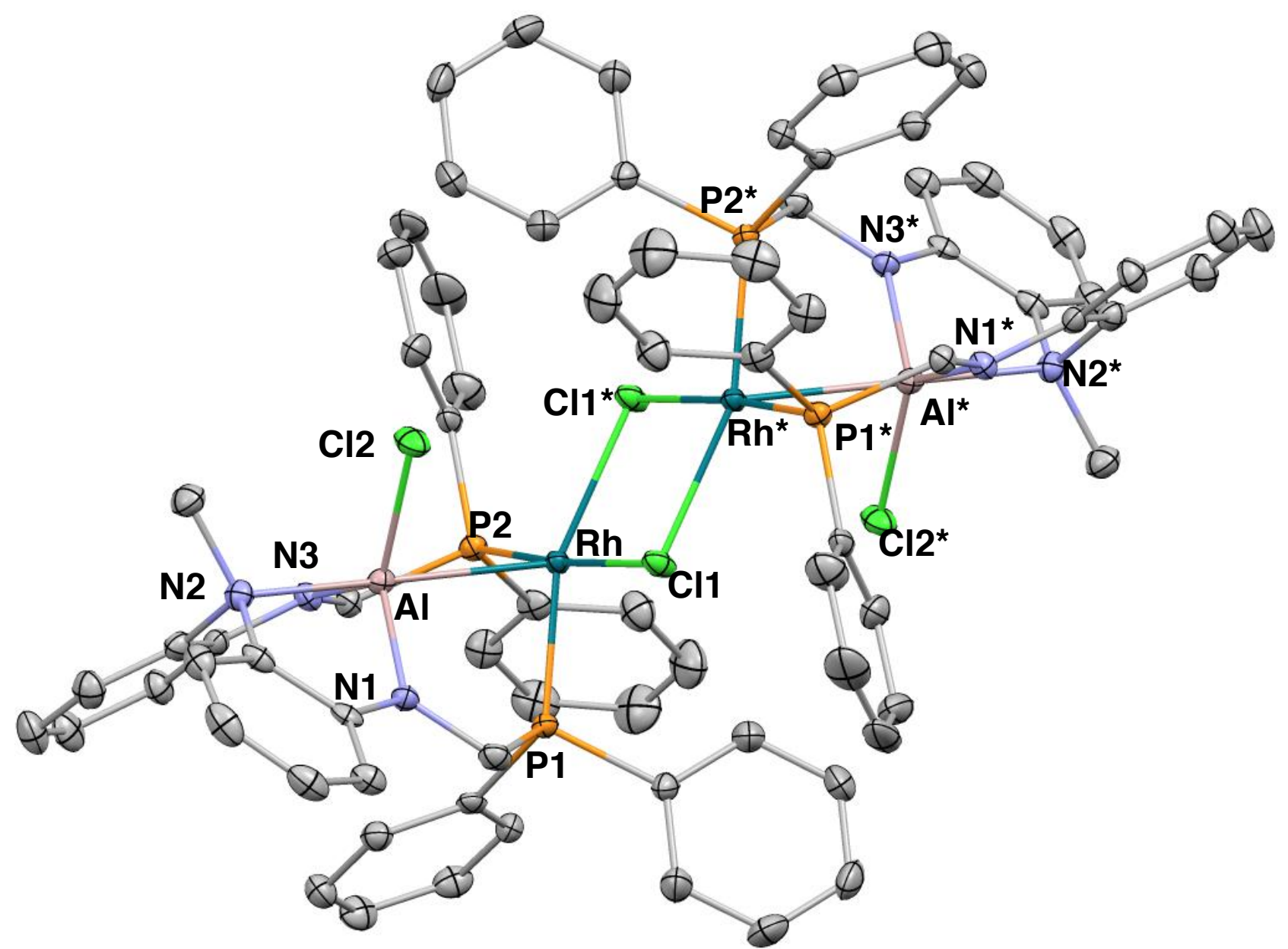

Figure S10. Crystal structure of $\mathbf{2 b}$ (atomic displacement parameters set at 30\% probability; all hydrogen atoms and solvent molecules are omitted for clarity). Selected bond lengths $[\AA]$ and angles [ $^{\circ}$ : Complex 2b: Rh-Al 2.6117(9), Rh-P1 2.2198(9), Rh-P2 2.2124(8), Rh-Cl1 2.4468(9), Al-Cl2 2.182(2), Al-N1 1.863(2), Al-N2 2.152(2), Al-N3 1.868(3), P1-Rh-P2 97.31(3), N2-Al-Rh 177.21(8), N1-Al-N3 114.8(1). 


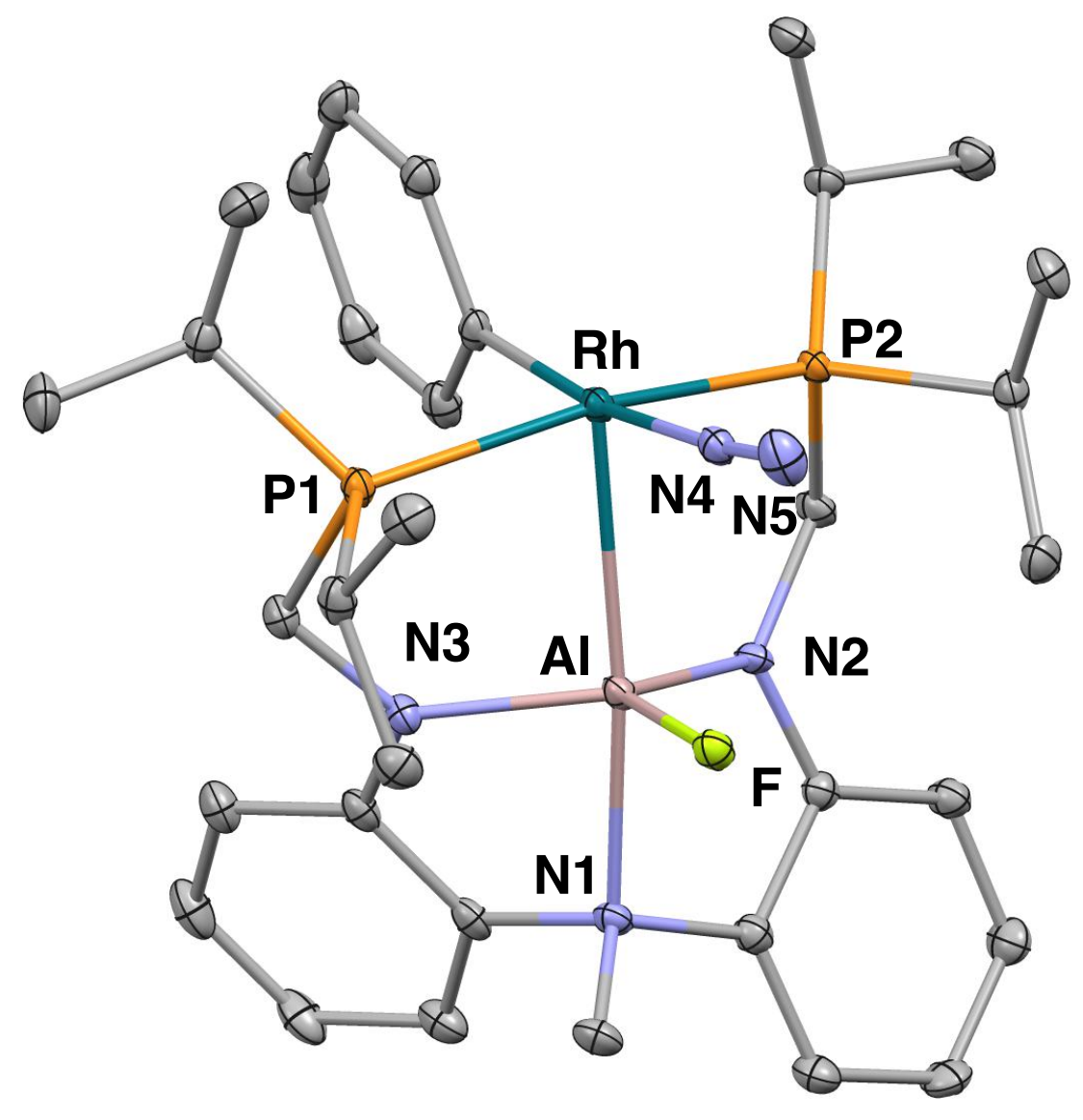

Figure S11. Crystal structure of 4 a (atomic displacement parameters set at 30\% probability; all hydrogen atoms and solvent molecules are omitted for clarity). Selected bond lengths $[\AA]$ and angles ${ }^{\circ}{ }^{\circ}$ : Complex 4a: Rh-Al 2.6098(8), Rh-P1 2.3342(8), Rh-P2 2.3090(8), Rh-C 2.039(3), Rh-N4 2.000(3), Al-F 1.687(2), Al-N1 2.105(2), Al-N2 1.883(2), Al-N3 1.873(2), N4-N5 1.090(4), P1Rh-P2 164.58(3), Rh-Al-N1 172.88(7), N2-Al-N3 124.1(1). 
Table S1. Crystallographic data of $2 b$ and $4 a$.

\begin{tabular}{|c|c|c|}
\hline compound & $\mathbf{2 b}$ & $4 \mathbf{a}$ \\
\hline empirical formula & $\mathrm{C}_{78} \mathrm{H}_{70} \mathrm{Al}_{2} \mathrm{Cl}_{4} \mathrm{~N}_{6} \mathrm{P}_{4} \mathrm{Rh}_{2}$ & $\mathrm{C}_{33} \mathrm{H}_{48} \mathrm{AlFN}_{5} \mathrm{P}_{2} \mathrm{Rh}$ \\
\hline formula weight & 1616.91 & 725.61 \\
\hline crystal system & monoclinic & triclinic \\
\hline space group & $P 121 / \mathrm{n} 1(\# 14)$ & $P \overline{1}(\# 2)$ \\
\hline$a, \AA$ & $14.3121(5)$ & $10.079(2)$ \\
\hline$b, \AA$ & $19.2665(6)$ & $11.873(2)$ \\
\hline$c, \AA$ & $15.4196(5)$ & $15.392(3)$ \\
\hline$\alpha$, deg. & 90 & $67.234(6)$ \\
\hline$\beta$, deg. & $112.521(4)$ & $80.582(7)$ \\
\hline$\gamma$, deg. & 90 & $87.293(9)$ \\
\hline$V, \AA^{3}$ & $3927.6(2)$ & $1675.3(6)$ \\
\hline$Z$ & 4 & 2 \\
\hline Dcalcd, $\mathrm{g} / \mathrm{cm}^{-3}$ & 1.511 & 1.438 \\
\hline$\mu[\mathrm{Mo}-K \alpha], \mathrm{mm}^{-1}$ & 0.845 & 0.667 \\
\hline$T, \mathrm{~K}$ & 143 & 143 \\
\hline crystal size, $\mathrm{mm}$ & $0.140 \times 0.120 \times 0.110$ & $0.090 \times 0.070 \times 0.060$ \\
\hline$\theta$ range for data collection (deg.) & 2.552 to 25.350 & 3.20 to 27.50 \\
\hline no. of reflections measured & 27345 & 13581 \\
\hline unique data & 7179 & 7303 \\
\hline data / restraints / parameters & 7179 / 0 / 461 & $7303 / 0 / 388$ \\
\hline$R 1(I>2.0 \sigma(I))$ & 0.0356 & 0.0381 \\
\hline$w R 2(I>2.0 \sigma(I))$ & 0.0733 & 0.0768 \\
\hline$R 1$ (all data) & 0.0495 & 0.0489 \\
\hline$w R 2$ (all data) & 0.0787 & 0.0812 \\
\hline GOF on $F^{2}$ & 1.031 & 1.006 \\
\hline
\end{tabular}

a) $R 1=(\Sigma|| F o|-| F c||) /(\Sigma|F o|)$ b) $w R 2=\left[\left\{\Sigma w\left(F o^{2}-F^{2}\right)^{2}\right\} /\left\{\sum w\left(F O^{4}\right)\right\}\right]^{1 / 2}$

\section{Computational details.}

Geometries were optimized by the DFT method with the B3PW9122-D323 functional in gas phase using small basis set system (BS-I). In BS-I, 6-31G(d) ${ }^{24}$ basis sets were used for $\mathrm{H}, \mathrm{C}, \mathrm{N}$, and F atoms and LANL2DZ ${ }^{25}$ basis sets were used for $\mathrm{Al}, \mathrm{P}$, and $\mathrm{Rh}$ atoms with corresponding effective core potentials (ECPs), where one $3 \mathrm{~d}$ polarization ${ }^{26}$ function was added to $\mathrm{Al}$ and $\mathrm{P}$ atoms. The B3PW91D3 functional was employed herein because the geometry of the Al-Rh complex could be reproduced well using this functional, as shown in Figure S12 and Table S2.

The potential energy was re-evaluated using the same functional with a better basis set system (BSII); in BS-II, 6-311G(d $)^{27}$ basis sets were used for H, C, N, F, and P atoms, 6-311+G(2d) ${ }^{28}$ basis set was used for Al atom, and the Stuttgart-Dresden-Bonn (SDB) ${ }^{29}$ basis set (311111/22111/411/11) with the corresponding ECPs was used for Rh atom. Solvation effect of THF was considered using PCM model. ${ }^{30}$ We selected the B3PW91-D3 functional for energy evaluation because the DFT calculation with this functional reproduced well the $\operatorname{CCSD}(\mathrm{T})$-calculated energy changes in $\mathrm{C}-\mathrm{F}$ bond activation by a model Al-Rh complex; the model reaction is shown in Figure S13 and the energy changes are presented in Table S3.

In this work, the discussion is presented using the Gibbs energy $(298.15 \mathrm{~K}, 1 \mathrm{~atm})$, where the translation entropy in solution was corrected with the method developed by Whitesides et al. ${ }^{31}$ All 
these calculations were carried out with the Gaussian 16 program. ${ }^{32}$

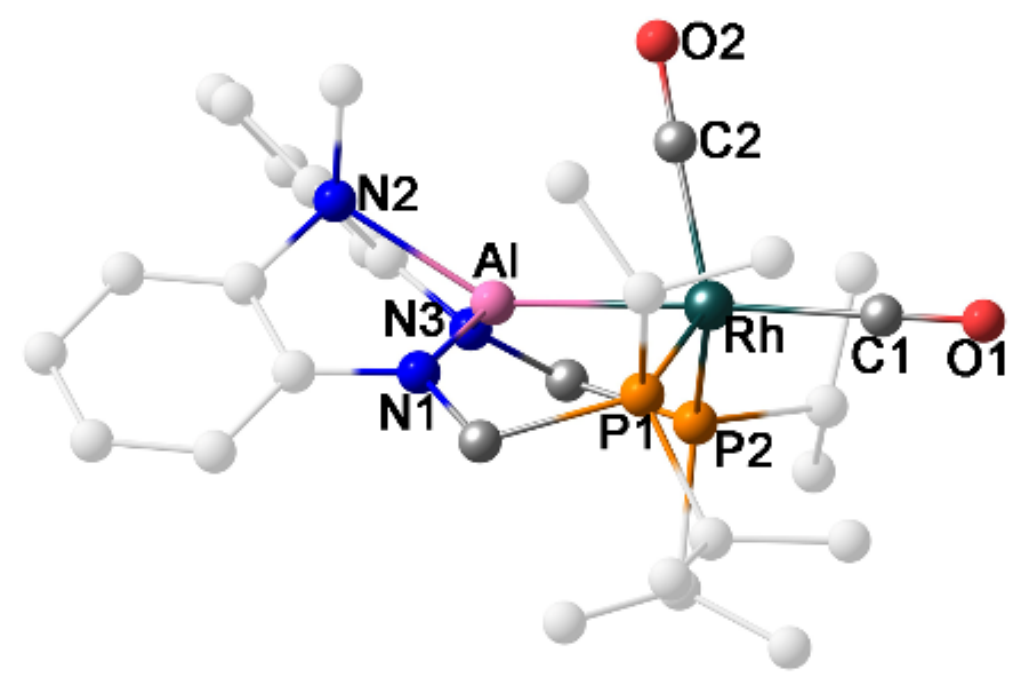

Figure S12. $\mathrm{Rh}(\mathrm{PAlP})(\mathrm{CO})_{2}$ used for test calculation of geometry optimization.

Table S2. Comparison of optimized bond distances $(\AA)$ with the experimental values of $\mathrm{Rh}(\mathrm{PAlP})(\mathrm{CO})_{2}$.

\begin{tabular}{cccccccccccc}
\hline & Rh-Al & Rh-P & Rh-P & Rh-C & Rh-C $^{2}$ & Al-N $^{1}$ & Al-N $^{2}$ & Al-N & C $^{1}-\mathrm{O}^{1}$ & C $^{2}-\mathrm{O}^{2}$ & RMSE \\
\hline Exp. & 2.439 & 2.362 & 2.344 & 1.935 & 1.874 & 1.812 & 2.094 & 1.837 & 1.139 & 1.149 & \\
B3PW91 & 2.457 & 2.410 & 2.399 & 1.934 & 1.890 & 1.868 & 2.141 & 1.879 & 1.157 & 1.165 & 0.037 \\
B3PW91-D3 & 2.435 & 2.381 & 2.368 & 1.931 & 1.891 & 1.861 & 2.118 & 1.873 & 1.158 & 1.166 & 0.025 \\
B3LYP-D3 & 2.447 & 2.415 & 2.402 & 1.954 & 1.901 & 1.862 & 2.123 & 1.873 & 1.158 & 1.167 & 0.036 \\
BP86-D3 & 2.448 & 2.389 & 2.390 & 1.932 & 1.896 & 1.884 & 2.112 & 1.875 & 1.175 & 1.183 & 0.035 \\
कB97XD & 2.441 & 2.406 & 2.391 & 1.940 & 1.897 & 1.856 & 2.124 & 1.870 & 1.153 & 1.161 & 0.030 \\
M06 & 2.466 & 2.454 & 2.429 & 1.964 & 1.913 & 1.860 & 2.116 & 1.871 & 1.157 & 1.165 & 0.048 \\
\hline
\end{tabular}

As shown in Table S2, the RMSE (root mean squared error) by the B3PW91-D3 functional is the smallest, suggesting that this functional can be used for geometry optimization of the Al-Rh complex. 


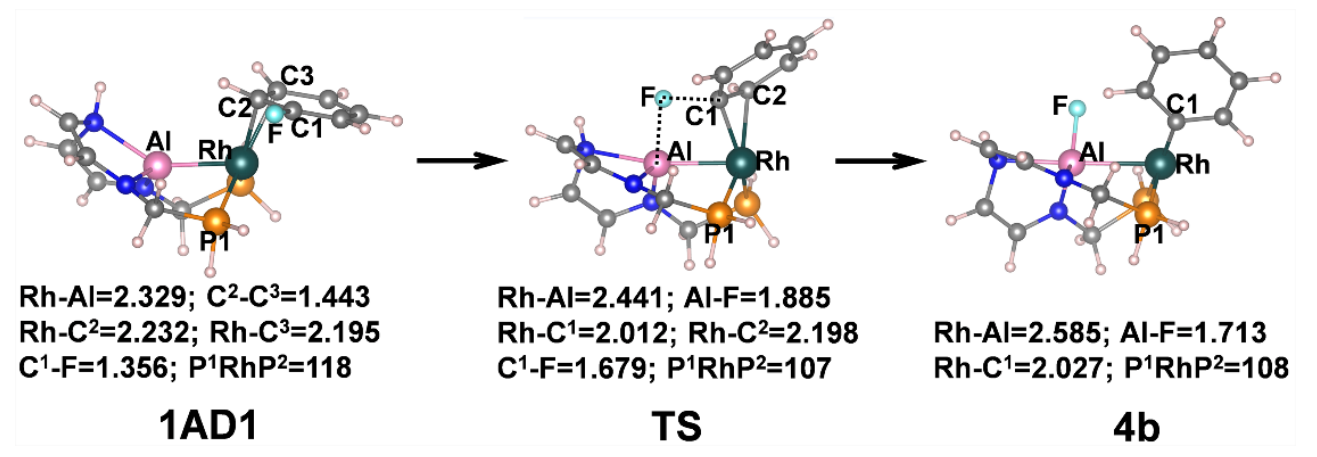

Figure S13. Geometry changes in a C-F bond cleavage of fluorobenzene using a model PAIP ligand. ${ }^{\text {a }}$ ${ }^{\mathrm{a}}$ In the model complex, phenyl groups on the $\mathrm{N}$ atoms were replaced with vinyl groups and iso-propyl groups on the $\mathrm{P}$ atoms were replaced with $\mathrm{H}$ atoms to reduce the size. The geometry of the other moiety was taken to be the same as the corresponding structure in the $\mathrm{C}-\mathrm{F}$ bond activation of $\mathrm{PhF}$ by $\mathrm{Rh}\left({ }^{\mathrm{Me}} \mathrm{PAlP}\right)$, in which iso-propyl groups on the $\mathrm{P}$ atoms were replaced with methyl groups for simplicity. Bond length is in angstrom and bond angle is in degree.

Table S3. Comparison of energy changes $\left(\mathrm{kcal} \mathrm{mol}^{-1}\right)$ between $\operatorname{CCSD}(\mathrm{T})$ and DFT calculations using various functionals in the model reaction shown in Figure S13.

\begin{tabular}{ccccc}
\hline & 1AD1 & TS & 4b & RMSE \\
\hline CCSD(T) & 0.0 & 3.7 & -40.9 & Ref. \\
B3PW91 & 0.0 & 6.2 & -38.0 & 2.7 \\
B3PW91-D3 & 0.0 & 3.7 & -40.7 & 0.1 \\
B3LYP-D3 & 0.0 & 2.4 & -45.8 & 3.6 \\
BP86-D3 & 0.0 & 1.2 & -37.8 & 2.8 \\
wB97XD & 0.0 & 4.2 & -43.6 & 2.0 \\
M06 & 0.0 & 2.3 & -41.9 & 1.2 \\
\hline
\end{tabular}

As shown in Table S3, the RMSE is the smallest in the case of the B3PW91-D3 calculation in various DFT functionals examined here, suggesting that this functional is useful for investigating this $\mathrm{C}-\mathrm{F}$ bond activation reaction. 

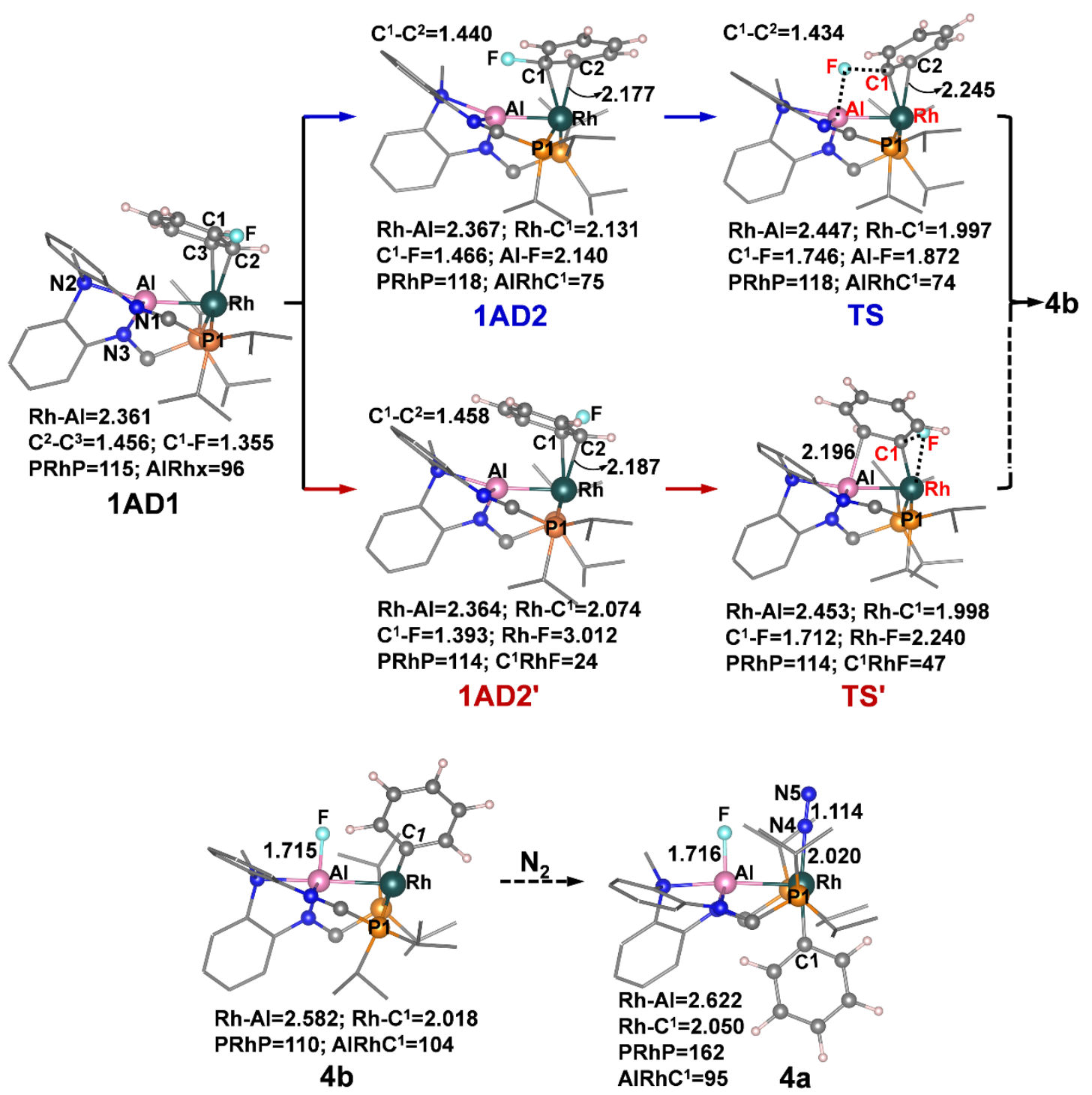

Figure S14. Geometry changes in the $\mathrm{C}-\mathrm{F}$ bond activation of $\mathrm{PhF}$ by $\mathrm{Rh}\left({ }^{i-\mathrm{Pr} P A l P}\right)$ complex, where the superscript $i$-Pr represents isopropyl phosphine. Bond length is in angstrom and bond angle is in degree.

\section{References}

(S1) Hara, N.; Saito, T.; Semba, K.; Kuriakose, N.; Zheng, H.; Sakaki, S.; Nakao, Y. Rhodium Complexes Bearing PAlP Pincer Ligands. J. Am. Chem. Soc. 2018, 140, 7070-7073.

(S2) Abel, E. W.; Bennett, M. A.; Wilkinson, G. Norbornadiene-metal complexes and some related compounds. J. Chem. Soc. 1959, 3178-3182.

(S3) Pangborn, A. B.; Giardello, M. A.; Grubbs, R. H.; Rosen, R. K.; Timmers, F. J. Safe and Convenient Procedure for Solvent Purification. Organometallics 1996, 15, 1518-1520.

(S4) Glasson, D. R.; Jayaweera, S. A. A. Formation and Reactivity of Nitrides II. Calcium and Magnesium Nitrides and Calcium Cyanamide. J. appl. Chem. 1968, 18, 77-83.

(S5) Correa, A.; Martin, R. Palladium-Catalyzed Direct Carboxylation of Aryl Bromides with Carbon Dioxide. J. Am. Chem. Soc. 2009, 131, 15974-15975. 
(S6) Murray, A. T.; Matton, P.; Fairhurst, N. W. G.; John, M. P.; Carbery, D. R. Biomimetic Flavin-Catalyzed Aldehyde Oxidation. Org. Lett. 2012, 14, 3656-3659.

(S7) Kraus, G. A. Method of Regioselective Synthesis of Substituted Benzoates. U.S. Patent WO 2013015918, January, 31, 2013.

(S8) (a) Gianetti, T. L.; Annen, S. P.; Santiso-Quinones, G.; Reiher, M.; Driess, M.; Grîtzmacher, H. Nitrous Oxide as a Hydrogen Acceptor for the Dehydrogenative Coupling of Alcohols. Angew. Chem. Int. Ed. 2016, 55, 1854-1858. (b) Kirai, N.; Yamamoto, Y. Homocoupling of Arylboronic Acids Catalyzed by 1,10-Phenanthroline-Ligated Copper Complexes in Air. Eur. J. Org. Chem. 2009, $1864-1867$.

(S9) (a) Wang, Z.-Q.; Tang, X.-S.; Yang, Z.-Q.; Yu, B.-Y.; Wang, H.-J.; Sang, W.; Yuan, Y.; Chen, C.; Verpoort, F. Highly active bidentate N-heterocyclic carbene/ruthenium complexes performing dehydrogenative coupling of alcohols and hydroxides in open air. Chem. Commun. 2019, 55, 8591-8594. (b) Liu, W.; Li, J.; Querard, P.; Li, C.-J. Transition-Metal-Free C-C, C-O, and C-N Cross-Couplings Enabled by Light. J. Am. Chem. Soc. 2019, 141, 6755-6764.

(S10) Giri, R.; Maugel, N.; Li, J.-J.; Wang, D.-H.; Breazzano, S. P.; Saunders, L. B.; Yu, J.-Q. Palladium-Catalyzed Methylation and Arylation of $\mathrm{sp}^{2}$ and $\mathrm{sp}^{3} \mathrm{C}-\mathrm{H}$ Bonds in Simple Carboxylic Acids. J. Am. Chem. Soc. 2007, 129, 3510-3511.

(S11) Klein, P.; Lechner, V. D.; Schimmel, T.; Hintermann, L. Generation of Organozinc Reagents by Nickel Diazadiene Complex Catalyzed Zinc Insertion into Aryl Sulfonates. Chem. Eur. J. 2020, 26, 176-180.

(S12) Kinuta, H.; Tobisu, M.; Chatani, N. Rhodium-Catalyzed Borylation of Aryl 2-Pyridyl Ethers through Cleavage of the Carbon-Oxygen Bond: Borylative Removal of the Directing Group. J. Am. Chem. Soc. 2015, 137, 1593-1600.

(S13) Schmink, J. R. Krska, S. W. Reversed-Polarity Synthesis of Diaryl Ketones via PalladiumCatalyzed Cross-Coupling of Acylsilanes. J. Am. Chem. Soc. 2011, 133, 19574-19577.

(S14) Tang, H.; Richey, H. G. Reactions of Diorganocadmium Compounds with Other Dialkylmetal Compounds and Macrocycles: Synthesis of Organocadmate Anions. Organometallics 2001, 20, 1569-1574.

(S15) Ashby, E. C.; Nackashi, J. The preparation of organomagnesium fluorides by organometallic exchange reactions. J. Organomet. Chem. 1974, 72, 11-20.

(S16) CrysAlisPRO: Agilent Technologies Ltd, Yarnton, Oxfordshire, England (2014).

(S17) Rigaku Corporation, 1999; and CrystalClear Software User's Guide, Molecular Structure Corporation, 2000.

(S18) Pflugrath, J. W. The Finer Things in X-ray Diffraction Data Collection. Acta Crystallogr. 1999, D55, 1718-1725.

(S19) Sheldrick, G. M. A Short History of SHELX. Acta Crystallogr. 2008, A64, 112-122.

(S20) Sheldrick, G. M. Crystal structure refinement with SHELXL. Acta Crystallogr. 2015, C71, $3-8$.

(S21) Altomare, A.; Cascarano, G.; Giacovazzo, C.; Guagliardi, A.; Bulra, M. C.; Polidori, G.; Camalli, M. SIR92 - a program for automatic solution of crystal structures by direct methods. J. Appl. 
Cryst. 1994, 27, 435.

(S22) (a) Becke, A. D. Density-Functional Exchange-Energy Approximation with Correct Asymptotic Behavior. Phys. Rev. A 1988, 38, 3098-3100. (b) Perdew, J. P.; Chevary, J. A.; Vosko, S. H.; Jackson, K. A.; Pederson, M. R.; Singh, D. J.; Fiolhais, C. Atoms, Molecules, Solids, and Surfaces: Applications of the Generalized Gradient Approximation for Exchange and Correlation. Phys. Rev. B 1992, 46, 6671-6687. (c) Becke, A. D. Density-Functional Thermochemistry. III. The Role of Exact Exchange. J. Chem. Phys. 1993, 98, 5648-5652. (d) Perdew, J. P.; Burke, K.; Wang, Y. Generalized Gradient Approximation for the Exchange-Correlation Hole of a Many-Electron System. Phys. Rev. B 1996, 54, 16533-16539.

(S23) Grimme, S.; Antony, J.; Ehrlich, S.; Krieg, H. A Consistent and Accurate Ab Initio Parametrization of Density Functional Dispersion Correction (DFT-D) for the 94 Elements H-Pu. $J$. Chem. Phys. 2010, 132, 154104.

(S24) (a) Ditchfield, R.; Hehre, W. J.; Pople, J. A. Self-Consistent Molecular-Orbital Methods. IX. An Extended Gaussian-Type Basis for Molecular-Orbital Studies of Organic Molecules. J. Chem. Phys. 1971, 54, 724-728. (b) Hehre, W. J.; Ditchfield, R.; Pople, J. A. Self-Consistent Molecular Orbital Methods. XII. Further Extensions of Gaussian-Type Basis Sets for Use in Molecular Orbital Studies of Organic Molecules. J. Chem. Phys. 1972, 56, 2257-2261. (c) Hariharan, P. C.; Pople, J. A. The Influence of Polarization Functions on Molecular Orbital Hydrogenation Energies. Theoret. Chim. Acta 1973, 28, 213-222.

(S25) (a) Wadt, W. R.; Hay, P. J. Ab Initio Effective Core Potentials for Molecular Calculations. Potentials for Main Group Elements Na to Bi. J. Chem. Phys. 1985, 82, 284-298. (b) Hay, P. J.; Wadt, W. R. Ab Initio Effective Core Potentials for Molecular Calculations. Potentials for K to Au Including the Outermost Core Orbitals. J. Chem. Phys. 1985, 82, 299-310.

(S26) (a) Höllwarth, A.; Böhme, M.; Dapprich, S.; Ehlers, A. W.; Gobbi, A.; Jonas, V.; Köhler, K. F.; Stegmann, R.; Veldkamp, A.; Frenking, G. A Set of d-Polarization Functions for Pseudo-Potential Basis Sets of the Main Group Elements Al-Bi and f-Type Polarization Functions For Zn, Cd, Hg. Chem. Phys. Lett. 1993, 208, 237-240. (b) Check, C. E.; Faust, T. O.; Bailey, J. M.; Wright, B. J.; Gilbert, T. M.; Sunderlin, L. S. Addition of Polarization and Diffuse Functions to the LANL2DZ Basis Set for P-Block Elements. J. Phys. Chem. A 2001, 105, 8111-8116.

(S27) (a) Krishnan, R.; Binkley, J. S.; Seeger, R.; Pople, J. A. Self-Consistent Molecular Orbital Methods. XX. A Basis Set for Correlated Wave Functions. J. Chem. Phys. 1980, 72, 650-654. (b) McLean, A. D.; Chandler, G. S. Contracted Gaussian Basis Sets for Molecular Calculations. I. Second Row Atoms, Z=11-18. J. Chem. Phys. 1980, 72, 5639-5648. (c) Francl, M. M.; Pietro, W. J.; Hehre, W. J.; Binkley, J. S.; Gordon, M. S.; Defrees, D. J.; Pople, J. A. Self-Consistent Molecular Orbital Methods. XXIII. A Polarization-Type Basis Set for Second-Row Elements. J. Chem. Phys. 1982, 77, 3654-3665.

(S28) Spitznagel, G. W.; Clark, T.; Schleyer, P. v. R.; Hehre, W. J. Efficient Diffuse FunctionAugmented Basis-Sets for Anion Calculation. IV. An Evaluation of the Performance of Diffuse Function-Augmented Basis-Sets for Second-Row Elements, Na-Cl. J. Comput. Chem. 1987, 8, 11091116. 
(S29) (a) Andrae, D.; Häußermann, U.; Dolg, M.; Stoll, H.; Preuß, H. Energy-Adjusted Ab Initio Pseudopotentials for the Second and Third Row Transition Elements. Theor. Chim. Acta 1990, 77, 123-141. (b) Martin, J. M. L.; Sundermann, A. Correlation Consistent Valence Basis Sets for Use with the Stuttgart-Dresden-Bonn Relativistic Effective Core Potentials: The Atoms Ga-Kr and In-Xe. J. Chem. Phys. 2001, 114, 3408-3420.

(S30) (a) Miertuš, S.; Scrocco, E.; Tomasi, J. Electrostatic Interaction of a Solute with a Continuum. A Direct Utilization of Ab Initio Molecular Potentials for the Prevision of Solvent Effects. Chem. Phys. 1981, 55, 117-129. (b) Miertuš, S.; Tomasi, J. Approximate Evaluations of the Electrostatic Free Energy and Internal Energy Changes in Solution Processes. Chem. Phys. 1982, 65, 239-245. (c) Pascual-Ahuir, J. L.; Silla, E.; Tuñon, I. Gepol: An Improved Description of Molecular Surfaces. III. A New Algorithm for the Computation of a Solvent-Excluding Surface. J. Comput. Chem. 1994, 15, 1127-1138. (d) Tomasi, J.; Mennucci, B.; Cammi, R. Quantum Mechanical Continuum Solvation Models. Chem. Rev. 2005, 105, 2999-3093.

(S31) Mammen, M.; Shakhnovich, E. I.; Deutch, J. M.; Whitesides, G. M. Estimating the Entropic Cost of Self-Assembly of Multiparticle Hydrogen-Bonded Aggregates Based on the Cyanuric Acid·Melamine Lattice. J. Org. Chem. 1998, 63, 3821-3830.

(S32) Frisch, M. J.; Trucks, G. W.; Schlegel, H. B.; Scuseria, G. E.; Robb, M. A.; Cheeseman, J. R.; Scalmani, G.; Barone, V.; Petersson, G. A.; Nakatsuji, H.; Li, X.; Caricato, M.; Marenich, A. V.; Bloino, J.; Janesko, B. G.; Gomperts, R.; Mennucci, B.; Hratchian, H. P.; Ortiz, J. V.; Izmaylov, A. F.; Sonnenberg, J. L.; Williams-Young, D.; Ding, F.; Lipparini, F.; Egidi, F.; Goings, J.; Peng, B.; Petrone, A.; Henderson, T.; Ranasinghe, D.; Zakrzewski, V. G.; Gao, J.; Rega, N.; Zheng, G.; Liang, W.; Hada, M.; Ehara, M.; Toyota, K.; Fukuda, R.; Hasegawa, J.; Ishida, M.; Nakajima, T.; Honda, Y.; Kitao, O.; Nakai, H.; Vreven, T.; Throssell, K.; Montgomery, J. A.; Jr.; Peralta, J. E.; Ogliaro, F.; Bearpark, M. J.; Heyd, J. J.; Brothers, E. N.; Kudin, K. N.; Staroverov, V. N.; Keith, T. A.; Kobayashi, R.; Normand, J.; Raghavachari, K.; Rendell, A. P.; Burant, J. C.; Iyengar, S. S.; Tomasi, J.; Cossi, M.; Millam, J. M.; Klene, M.; Adamo, C.; Cammi, R.; Ochterski, J. W.; Martin, R. L.; Morokuma, K.; Farkas, O.; Foresman, J. B.; Fox, D. J. Gaussian 16, revision B.01; Gaussian, Inc.: Wallingford, CT, 2016. 

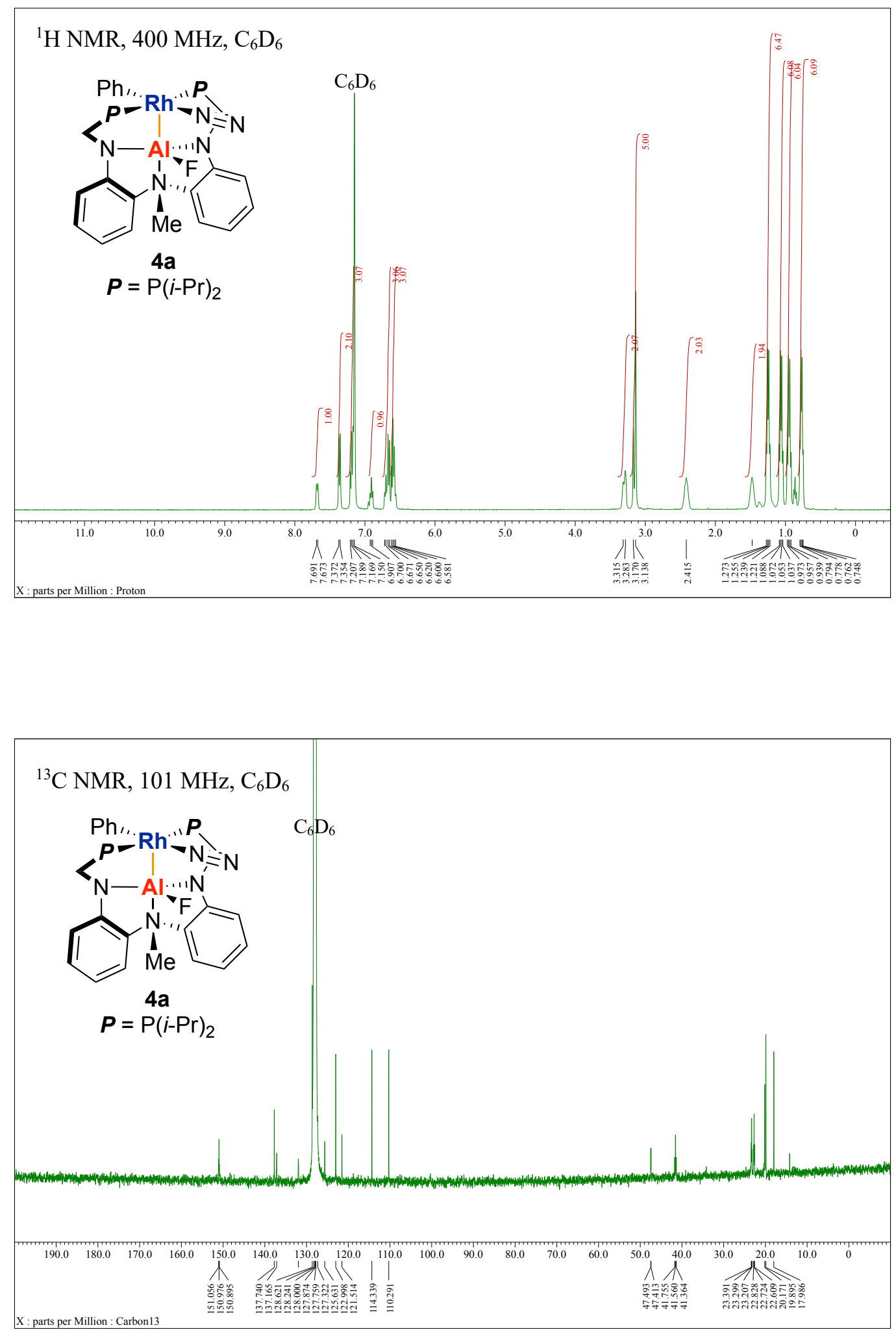

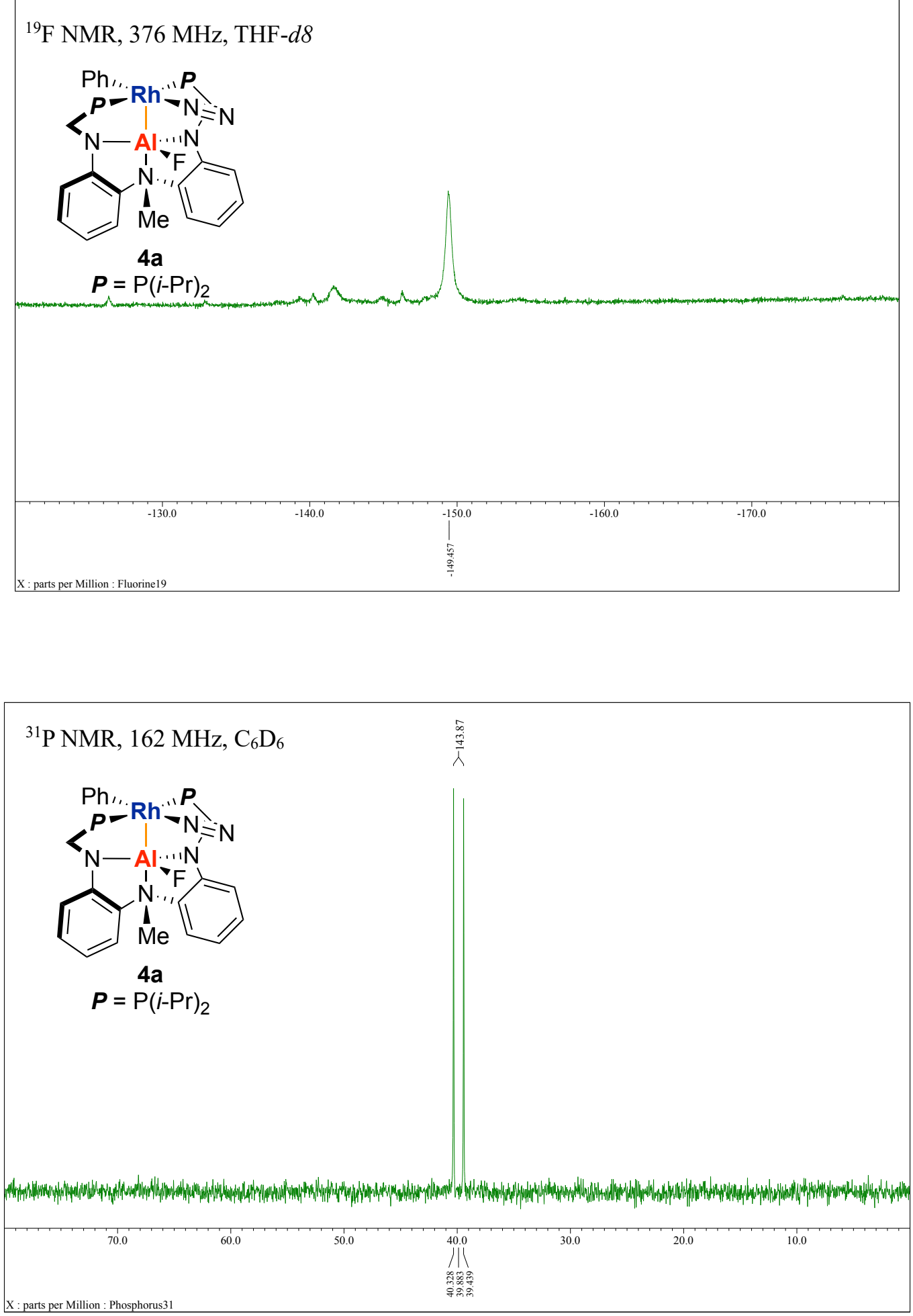


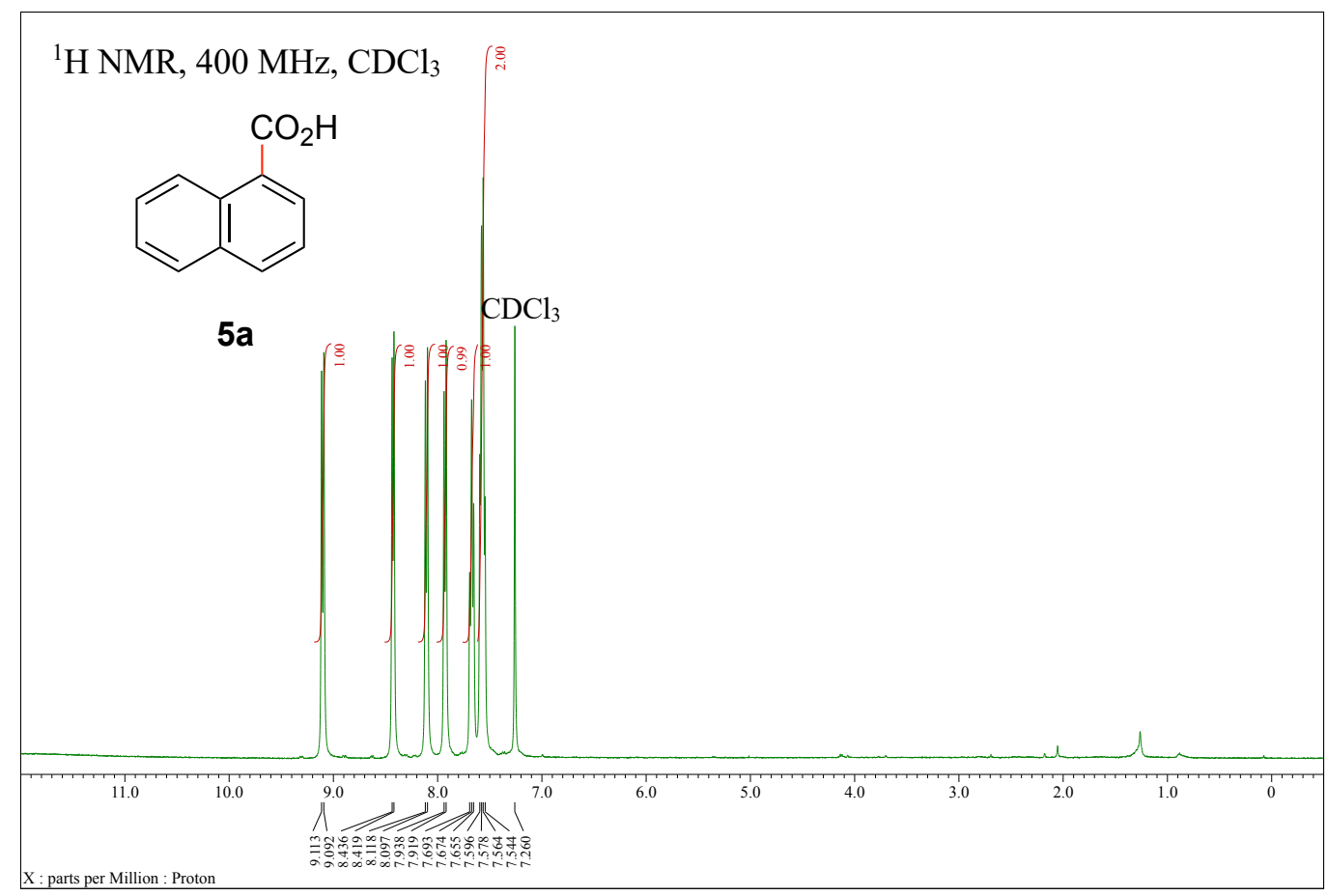

${ }^{13} \mathrm{C}$ NMR, $101 \mathrm{MHz}, \mathrm{CDCl}_{3}$<smiles>O=C(O)c1cccc2ccccc12</smiles>

$\mathrm{CDCl}_{3}$

$5 a$
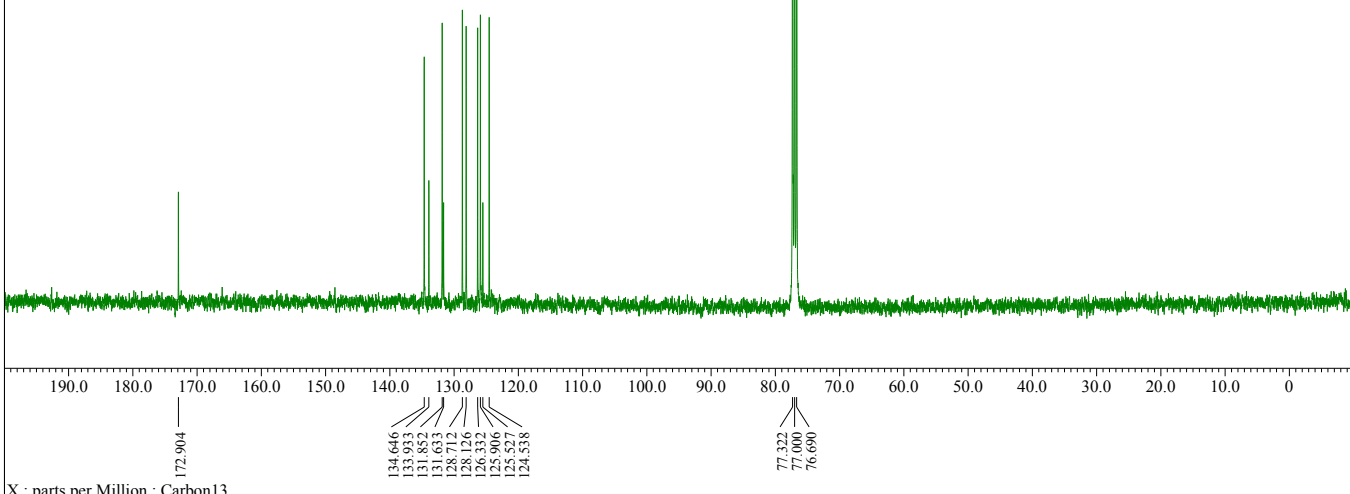

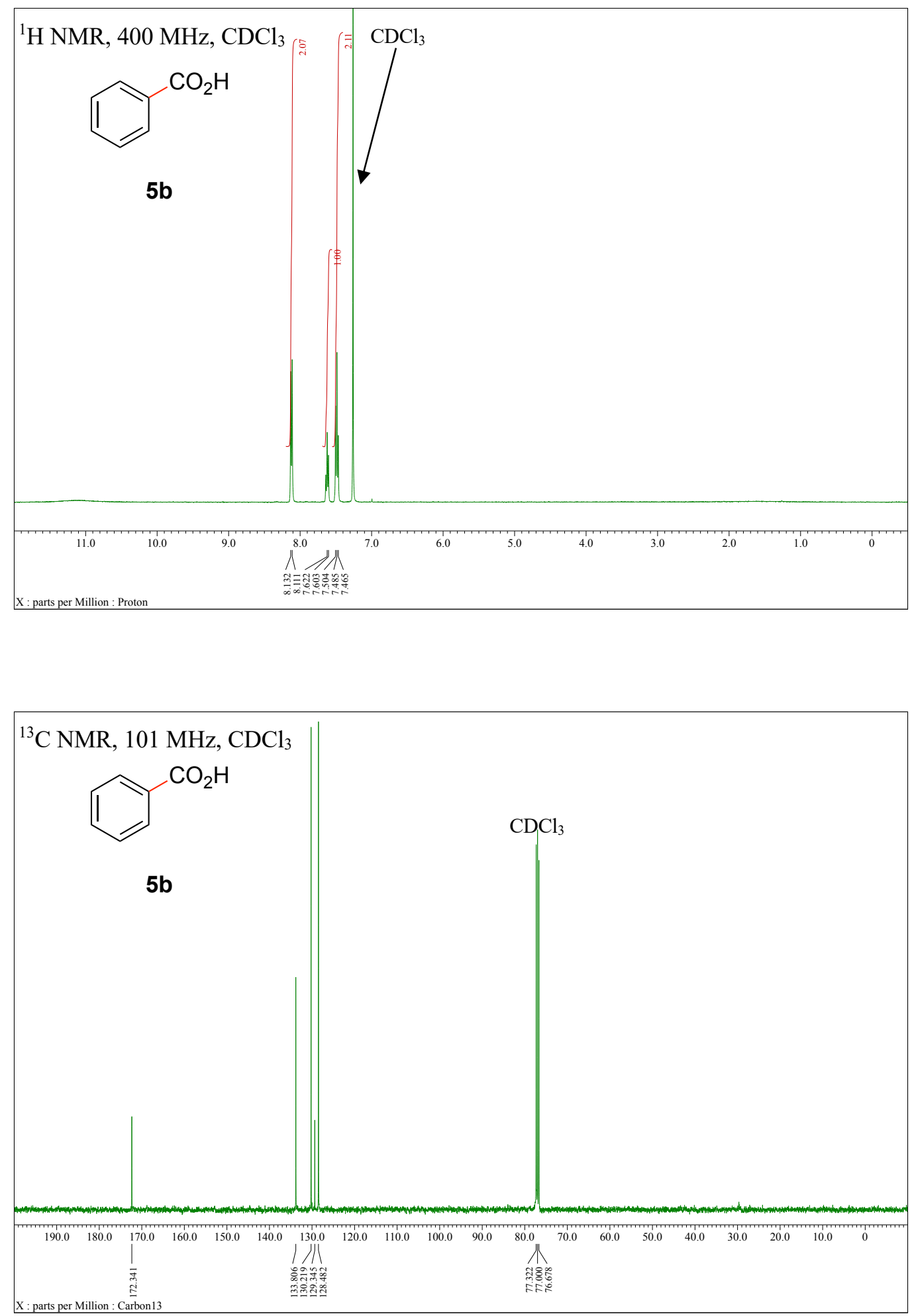

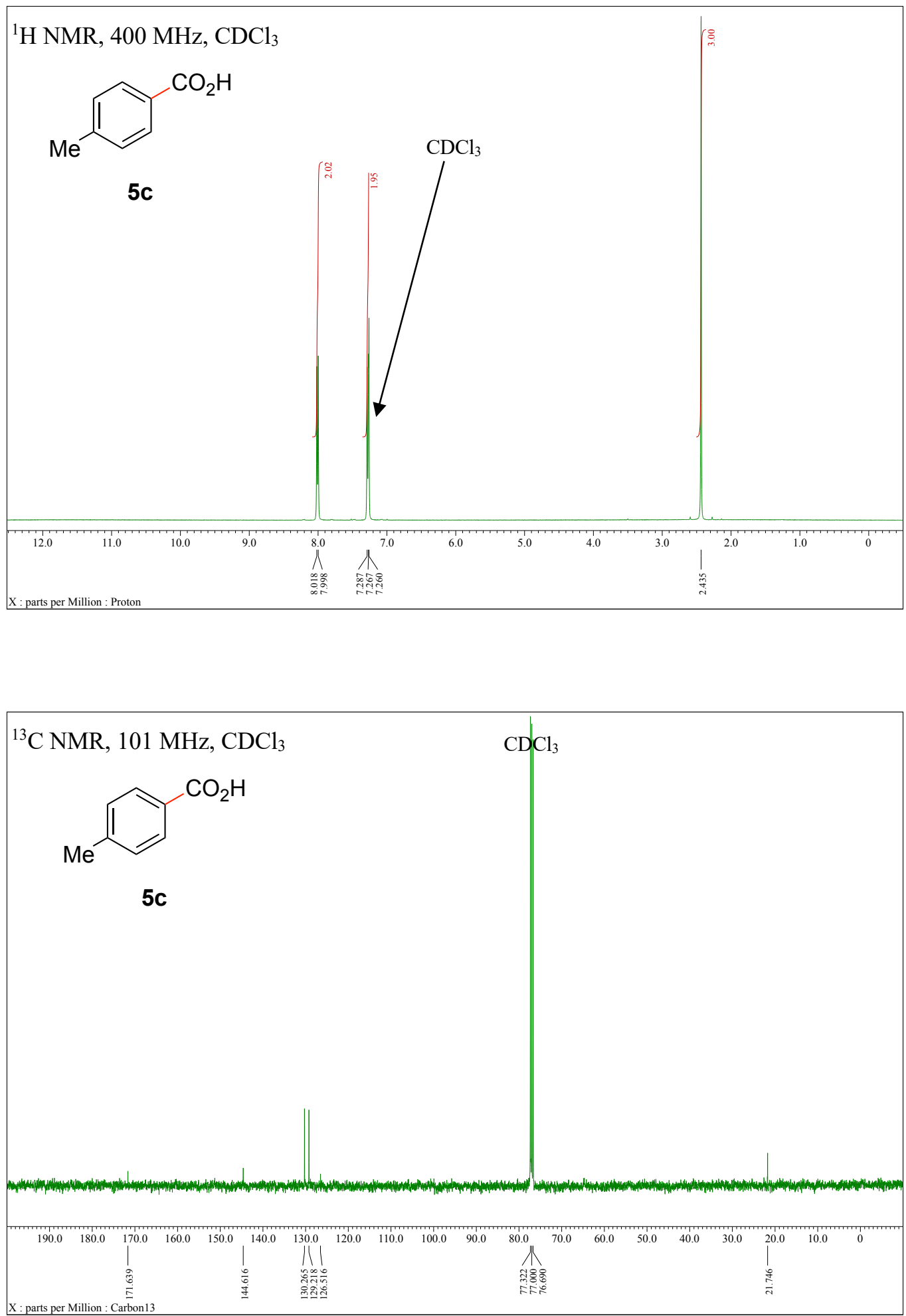


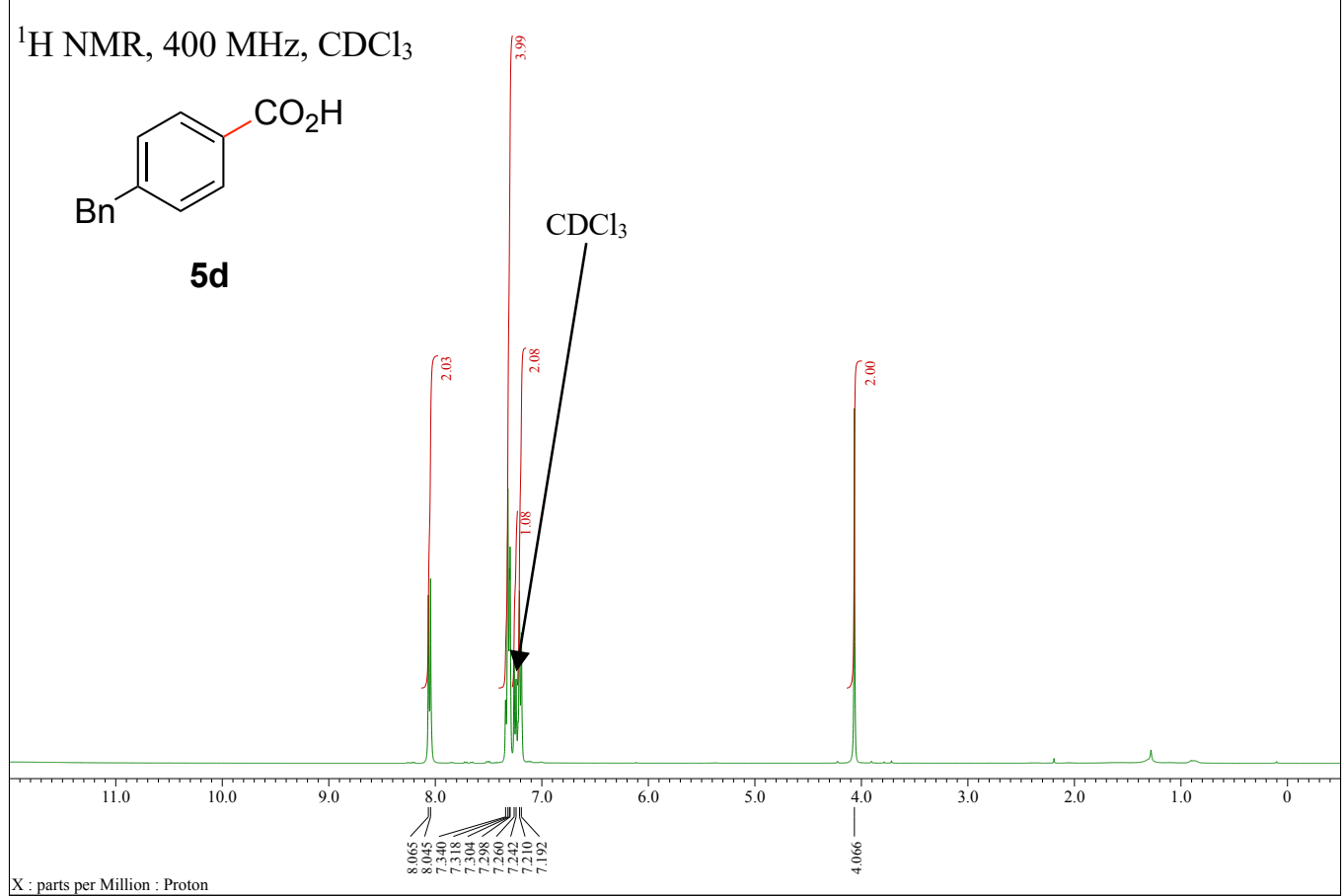

${ }^{13} \mathrm{C}$ NMR, $101 \mathrm{MHz}, \mathrm{CDCl}_{3}$

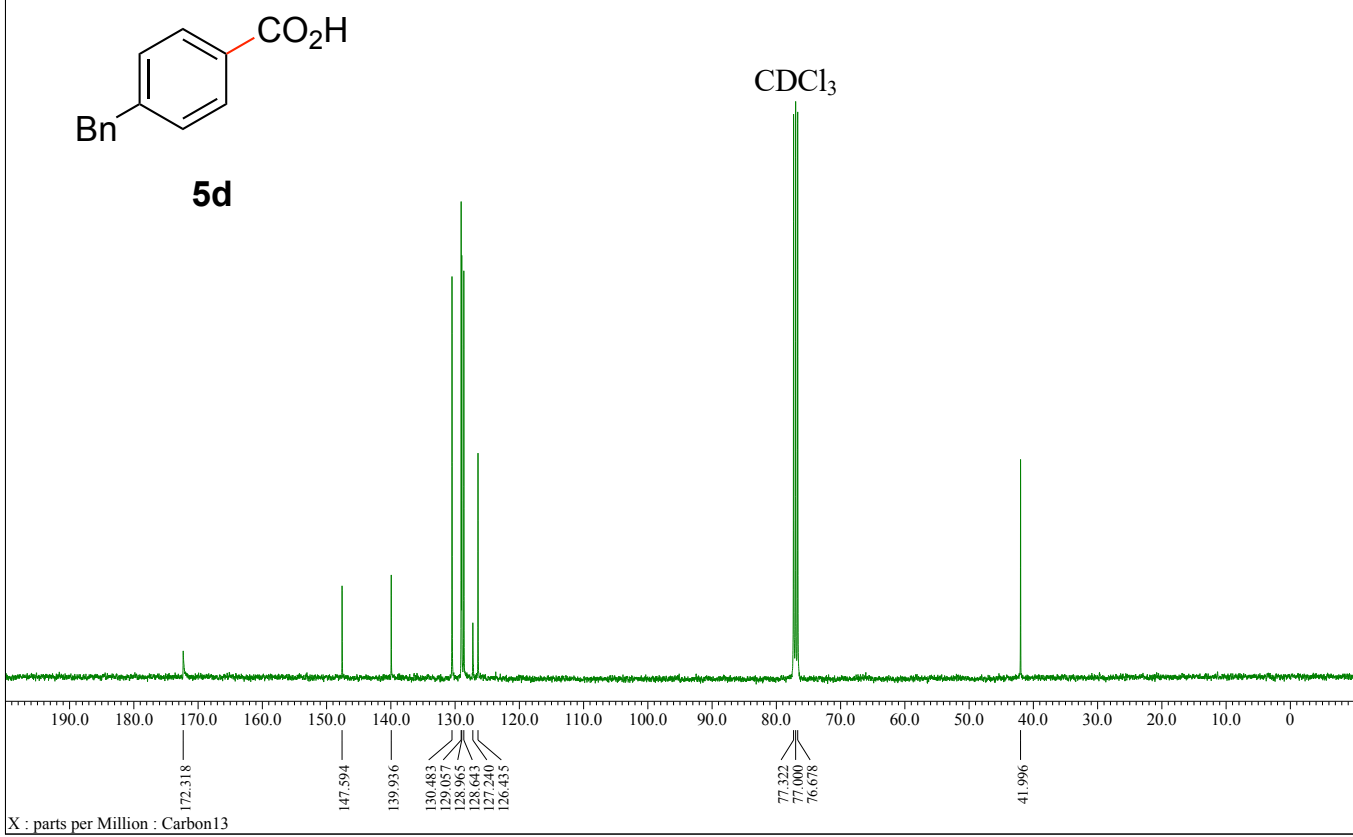



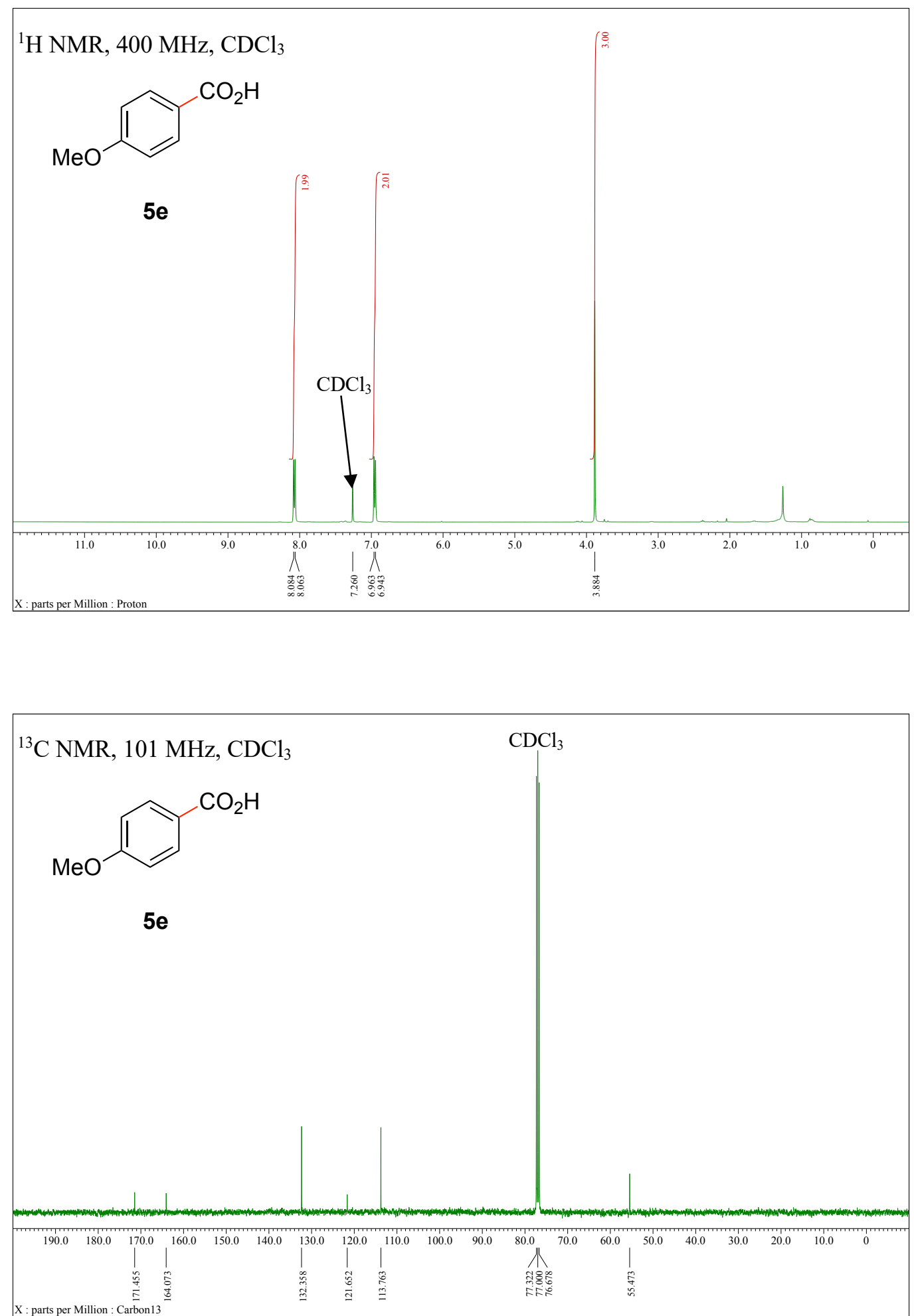

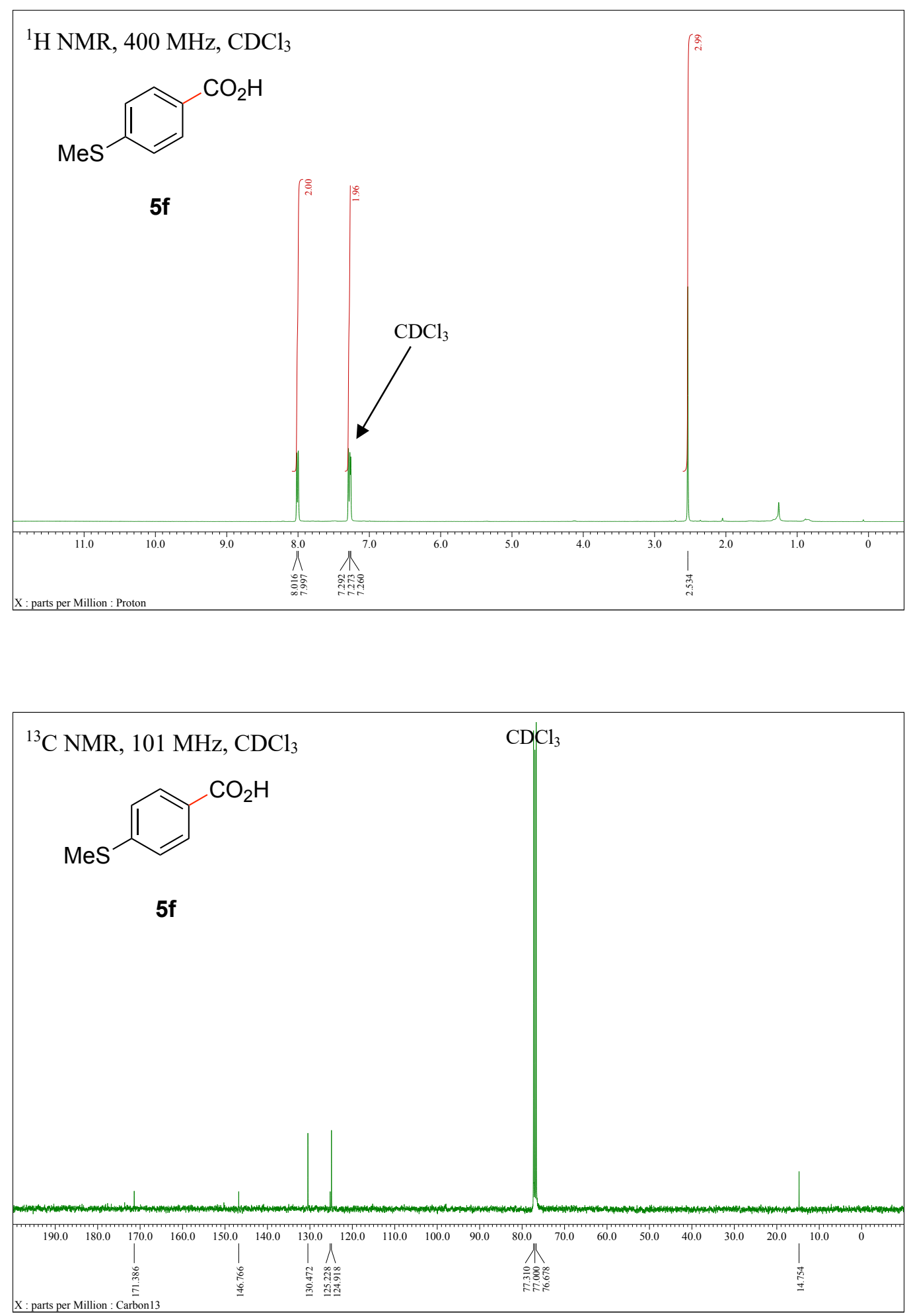

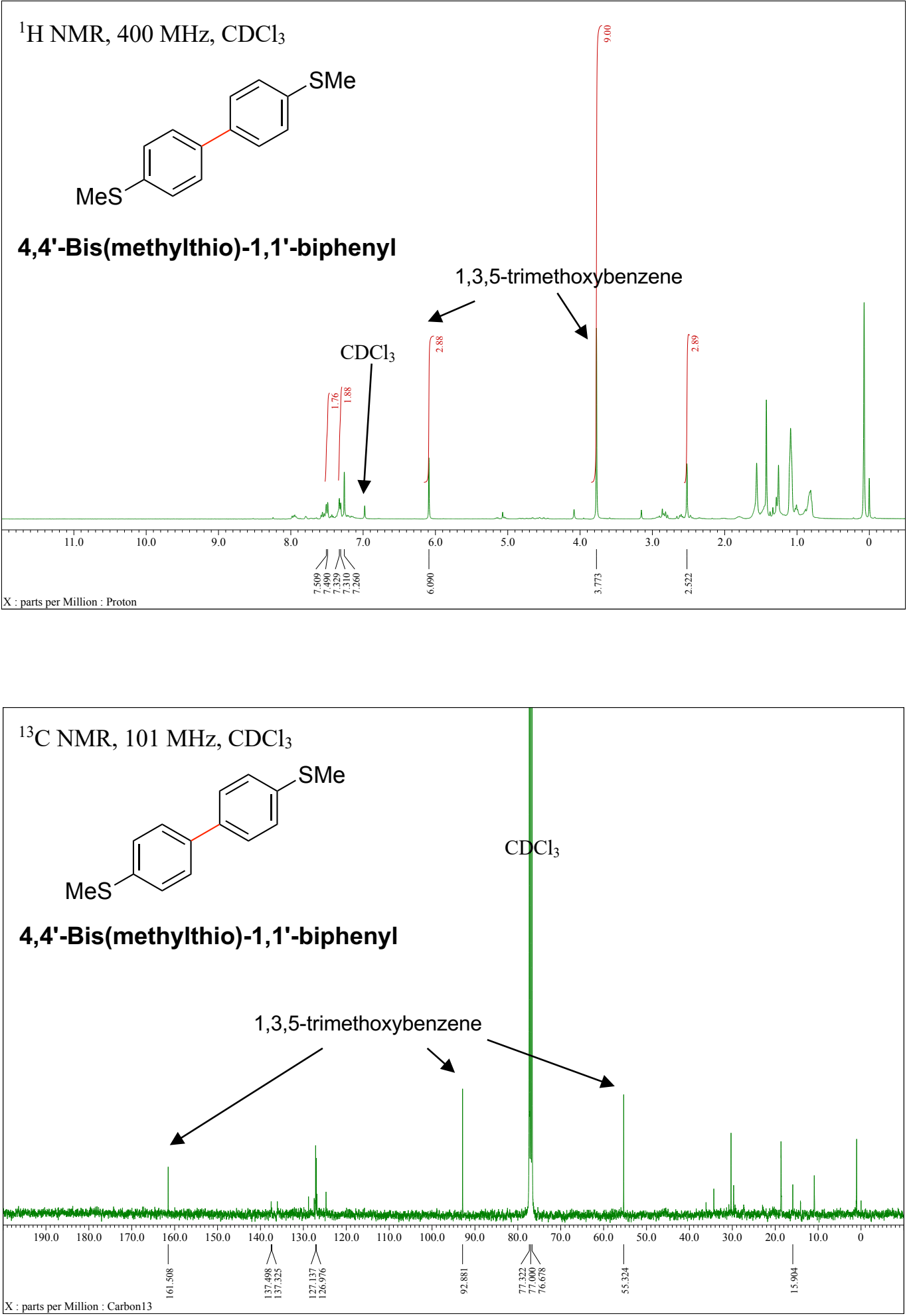

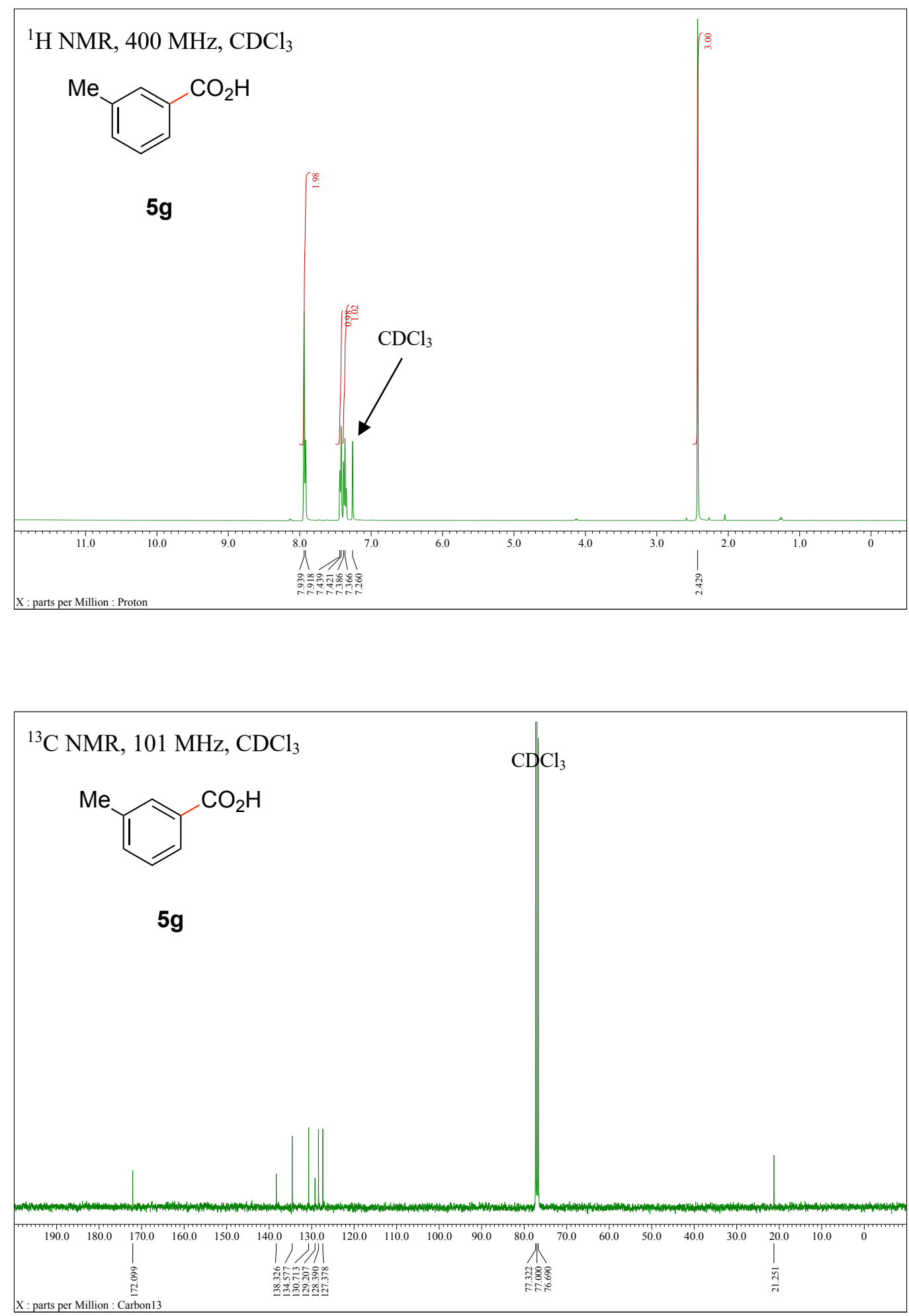


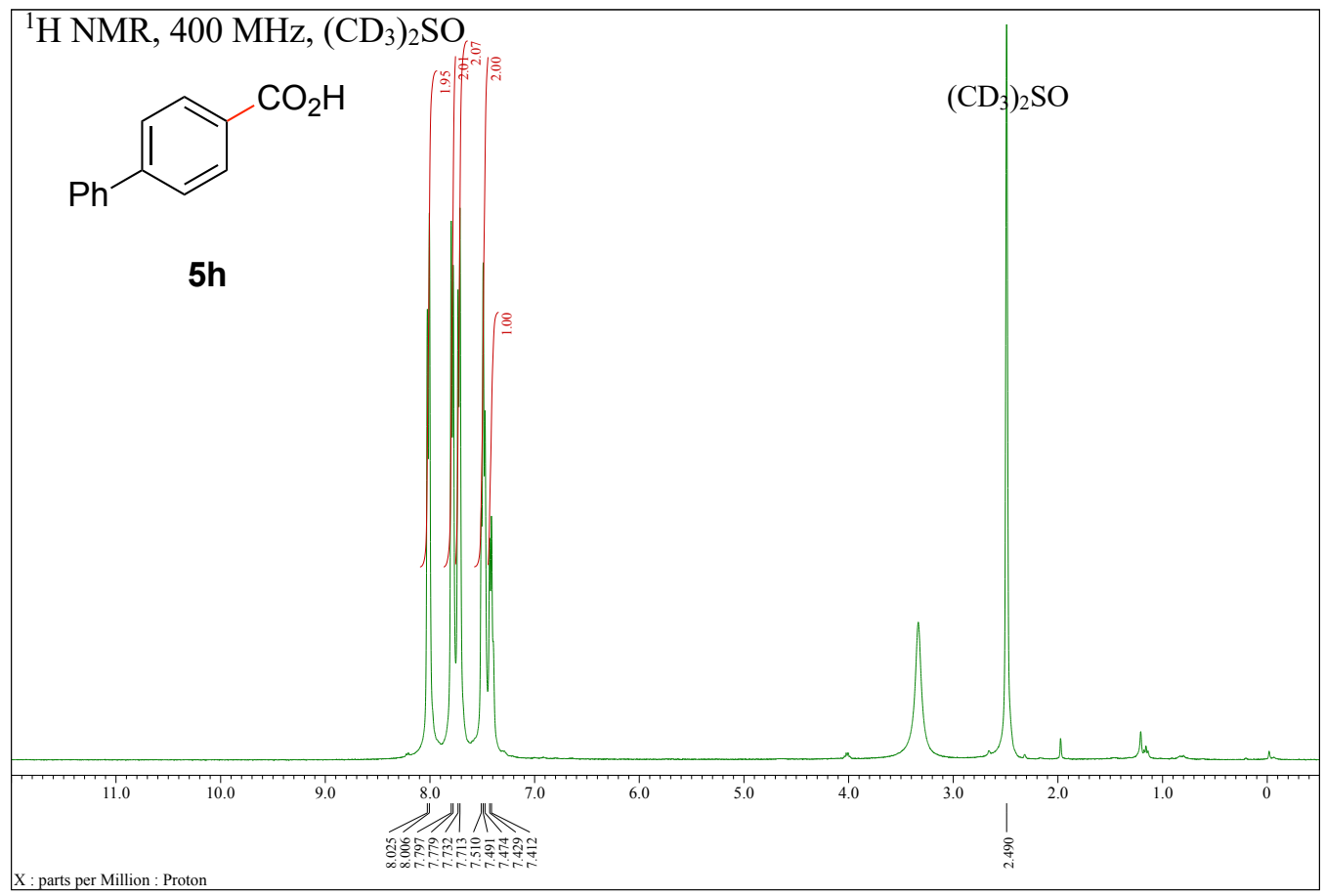

${ }^{13} \mathrm{C}$ NMR, $101 \mathrm{MHz},\left(\mathrm{CD}_{3}\right)_{2} \mathrm{SO}$

$\left(\mathrm{CD}_{3}\right)_{2} \mathrm{SO}$<smiles>O=C(O)c1ccc(-c2ccccc2)cc1</smiles>

$5 \mathrm{~h}$

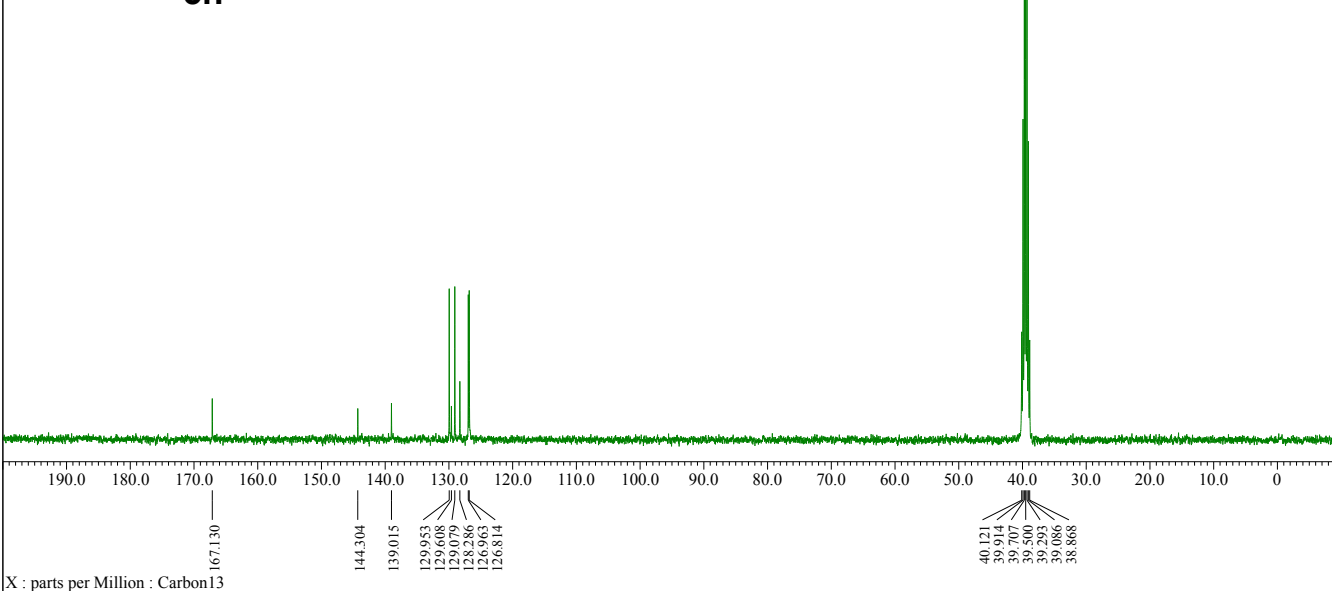



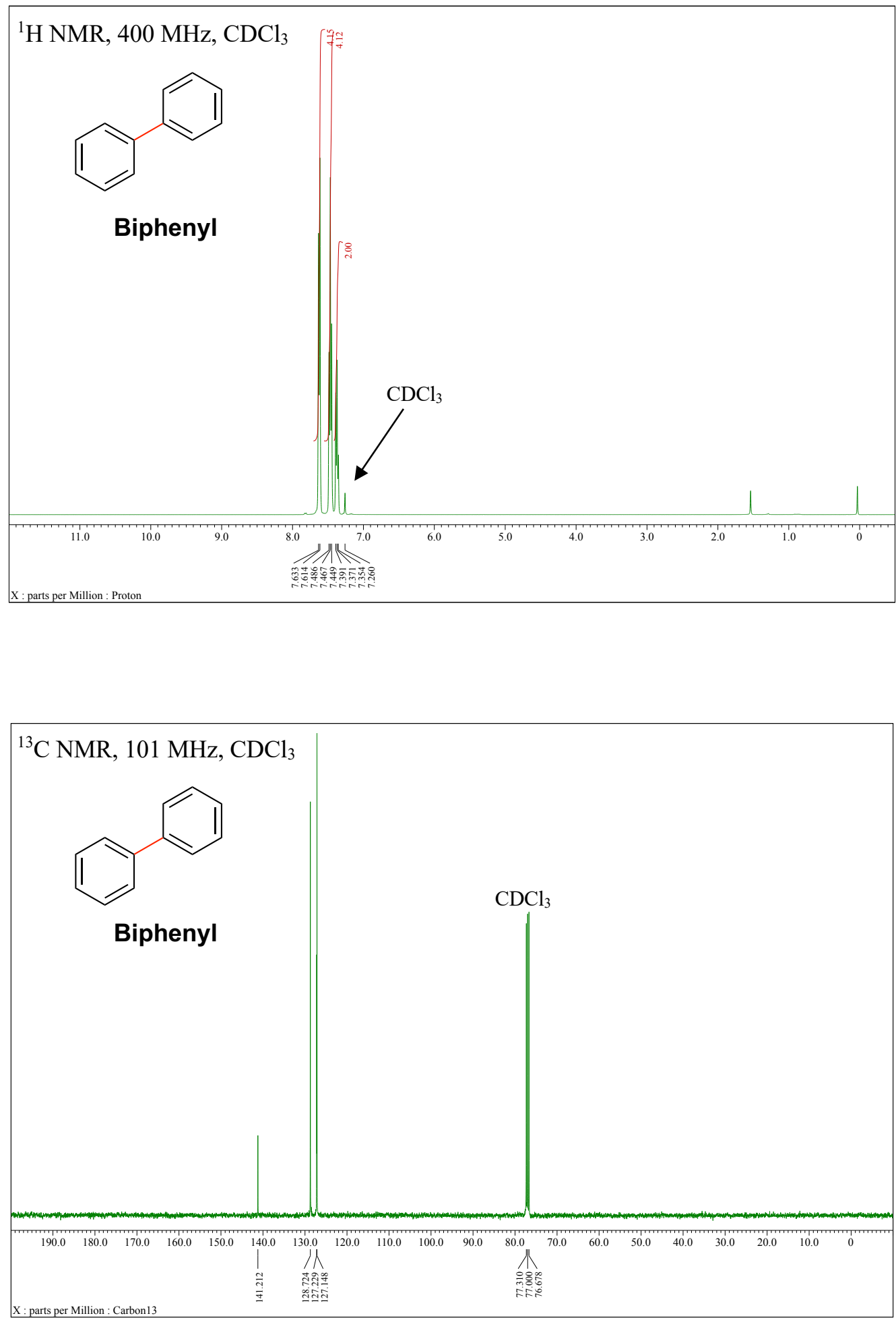

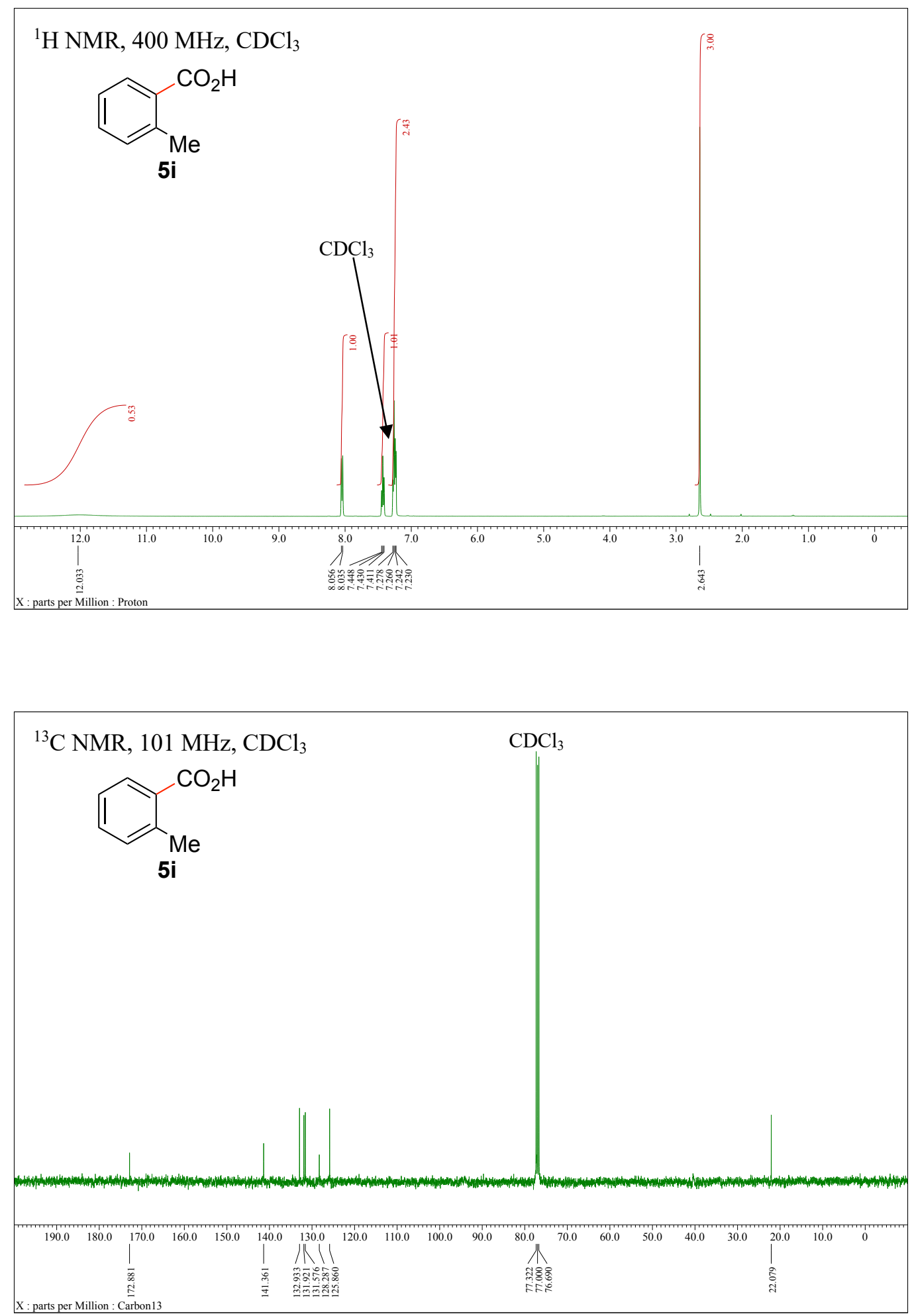

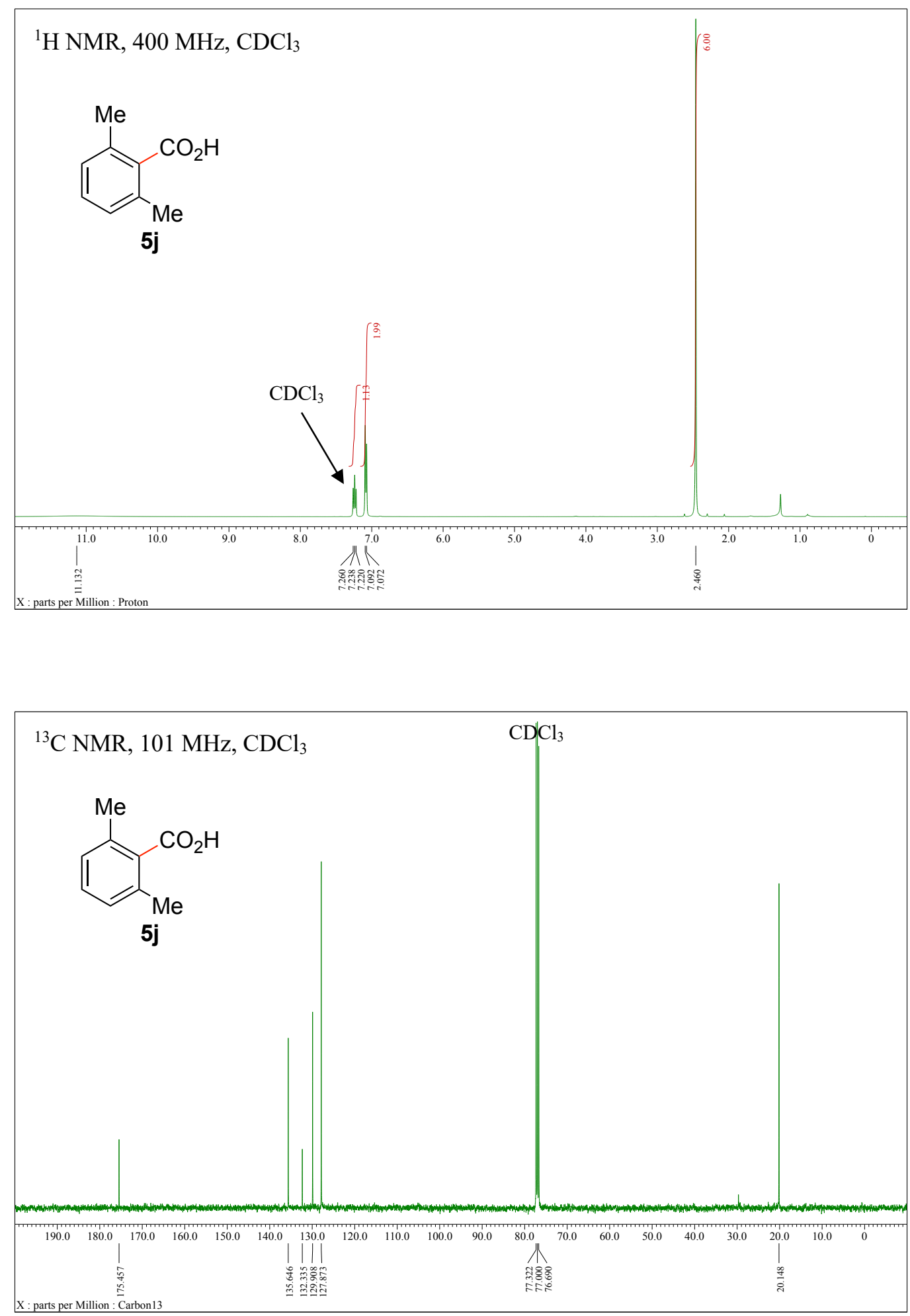


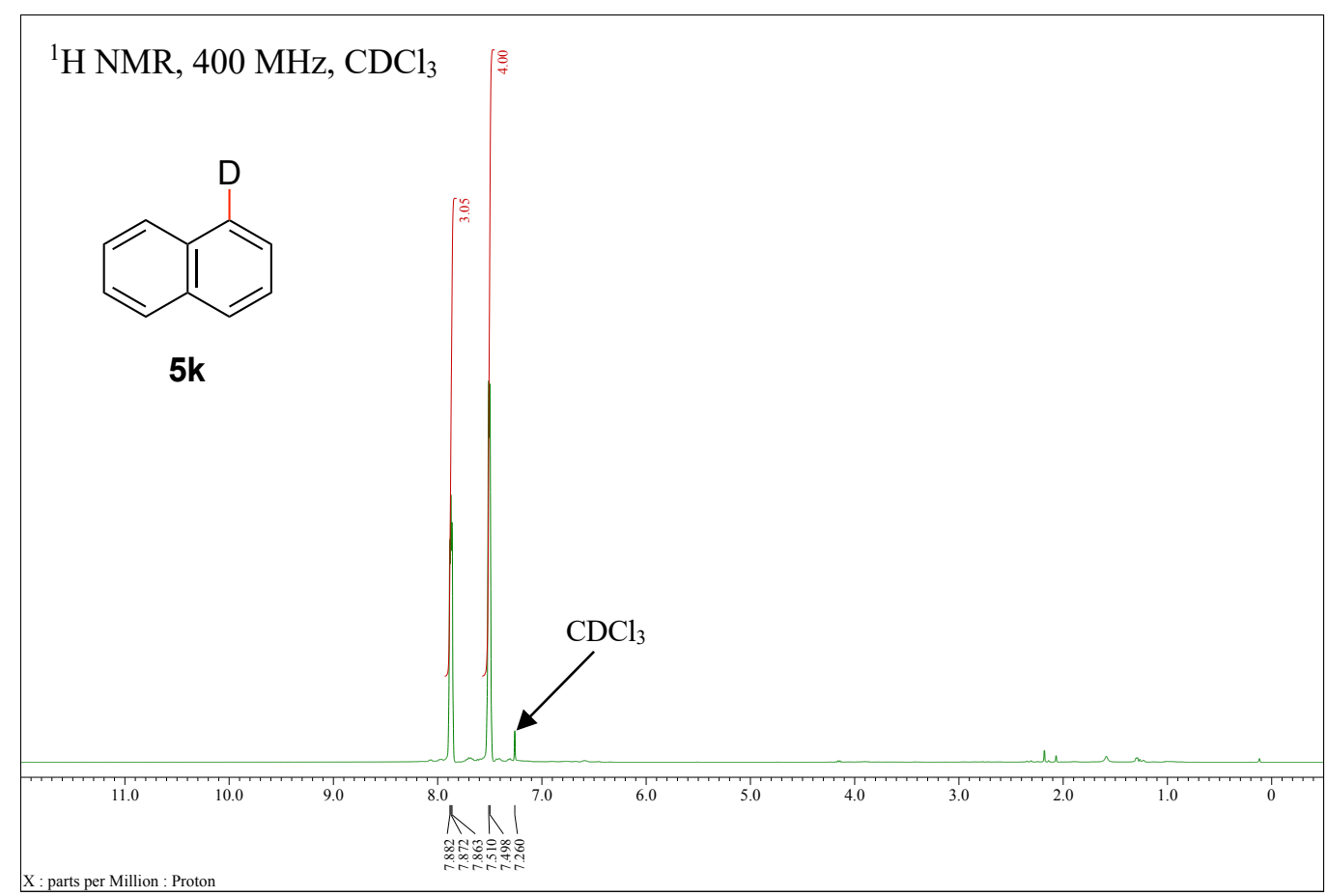

${ }^{2} \mathrm{H}$ NMR, $61 \mathrm{MHz}, \mathrm{CDCl}_{3}$<smiles>[2H]c1cccc2ccccc12</smiles>

$5 \mathrm{k}$

\begin{tabular}{|c|c|c|c|c|c|c|c|c|c|c|}
\hline 11.0 & 10.0 & 9.0 & 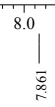 & 7.0 & 6.0 & 5.0 & 4.0 & 3.0 & 2.0 & 1.0 \\
\hline
\end{tabular}



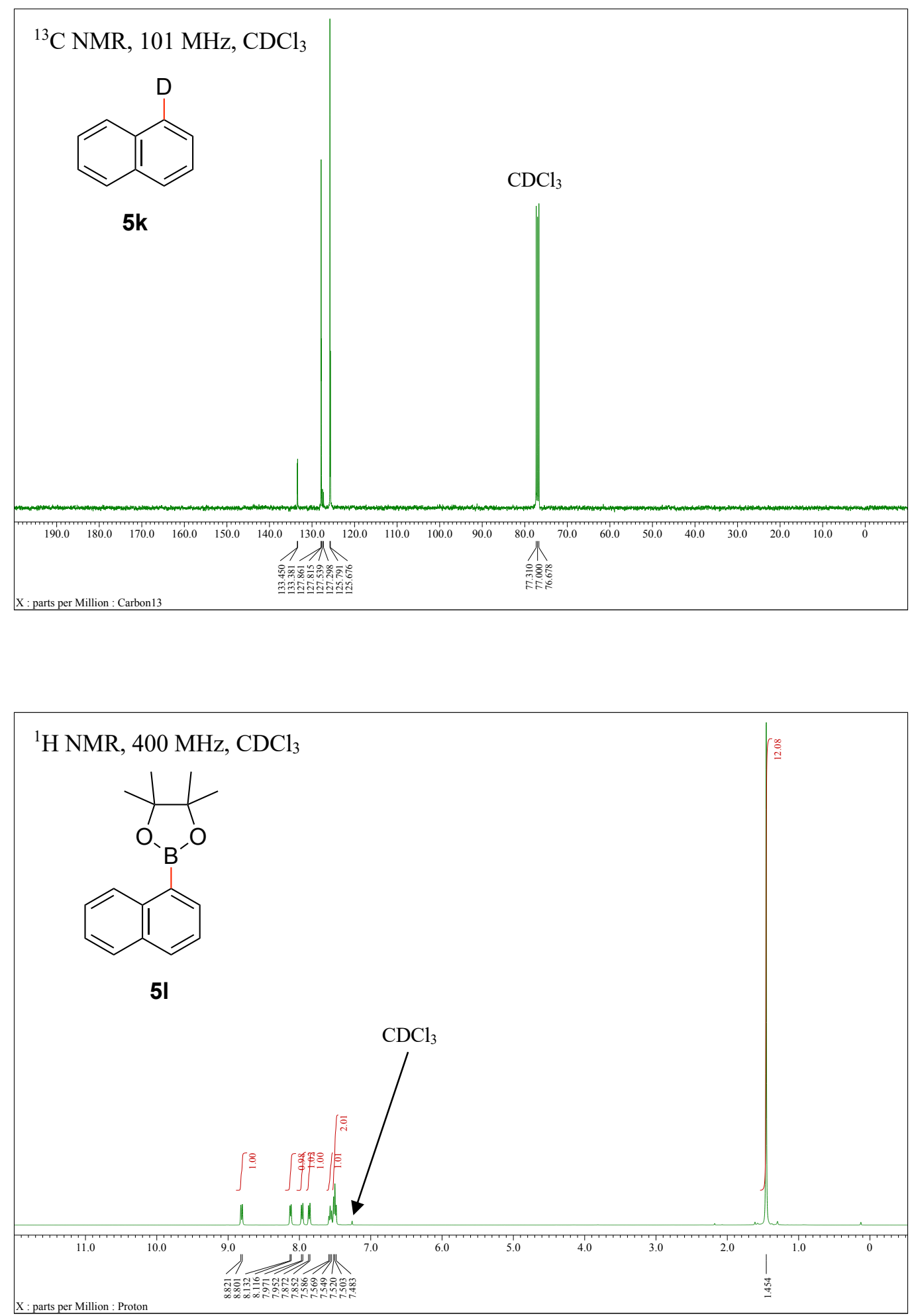


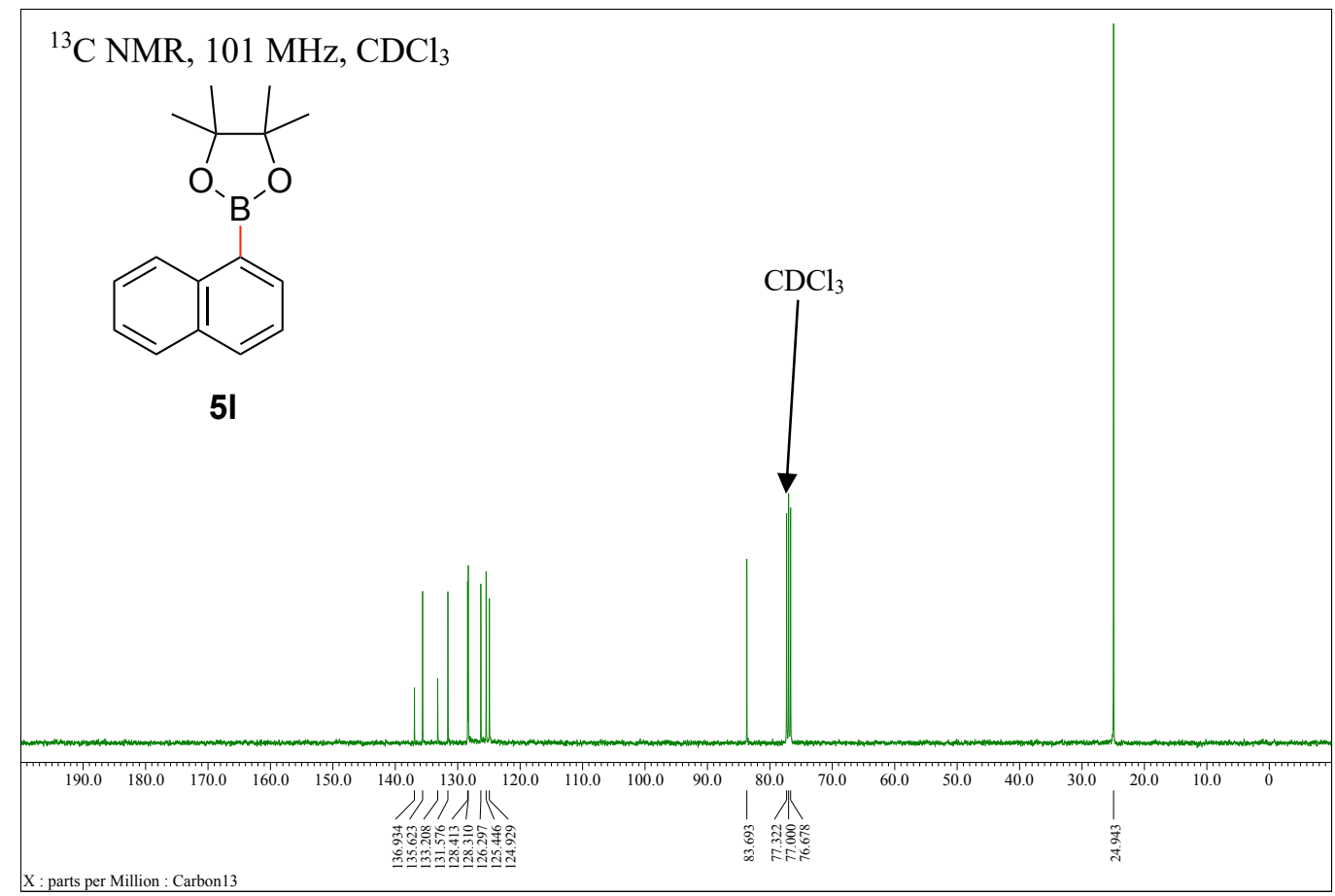

${ }^{11} \mathrm{~B}$ NMR, $128 \mathrm{MHz}, \mathrm{CDCl}_{3}$

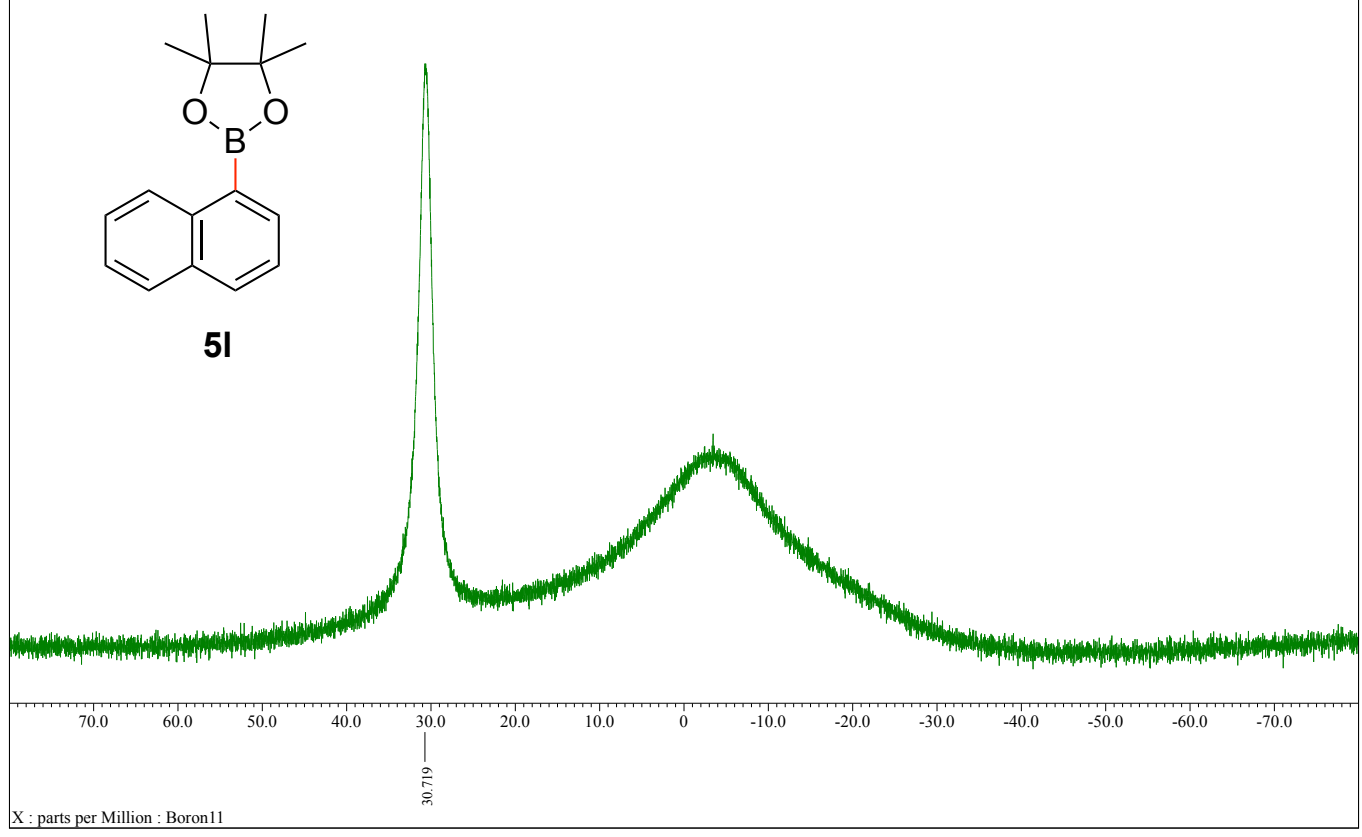



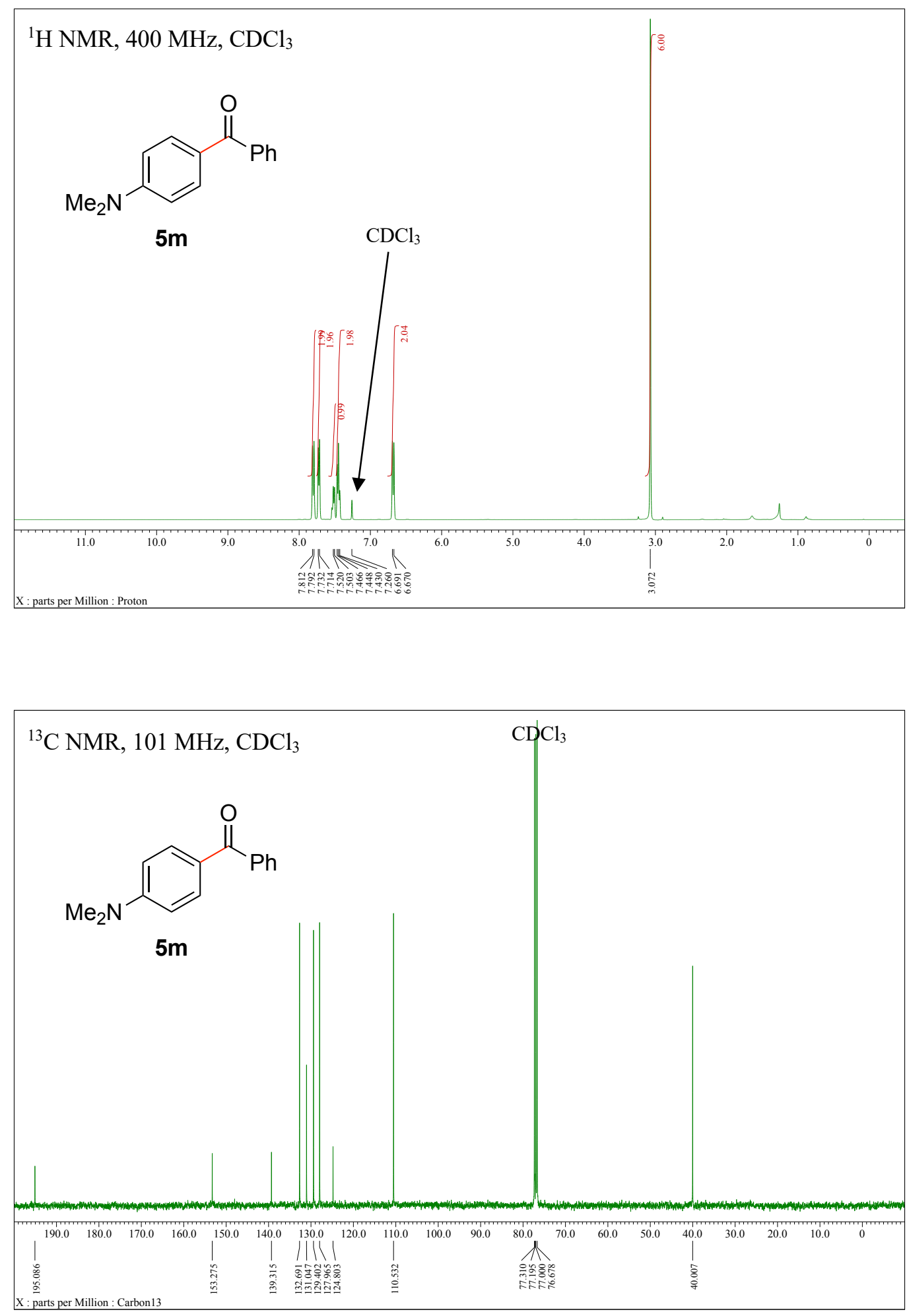

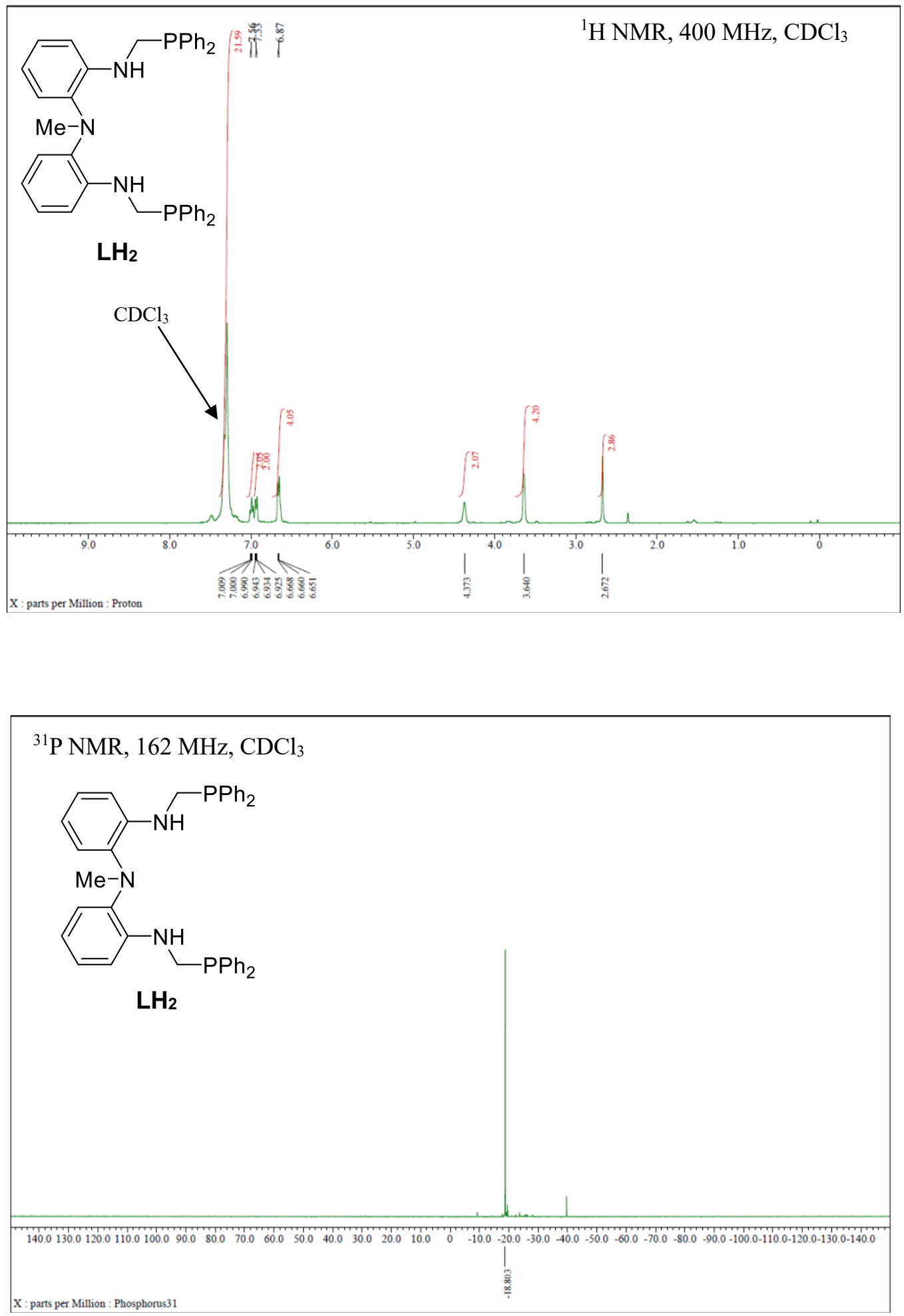

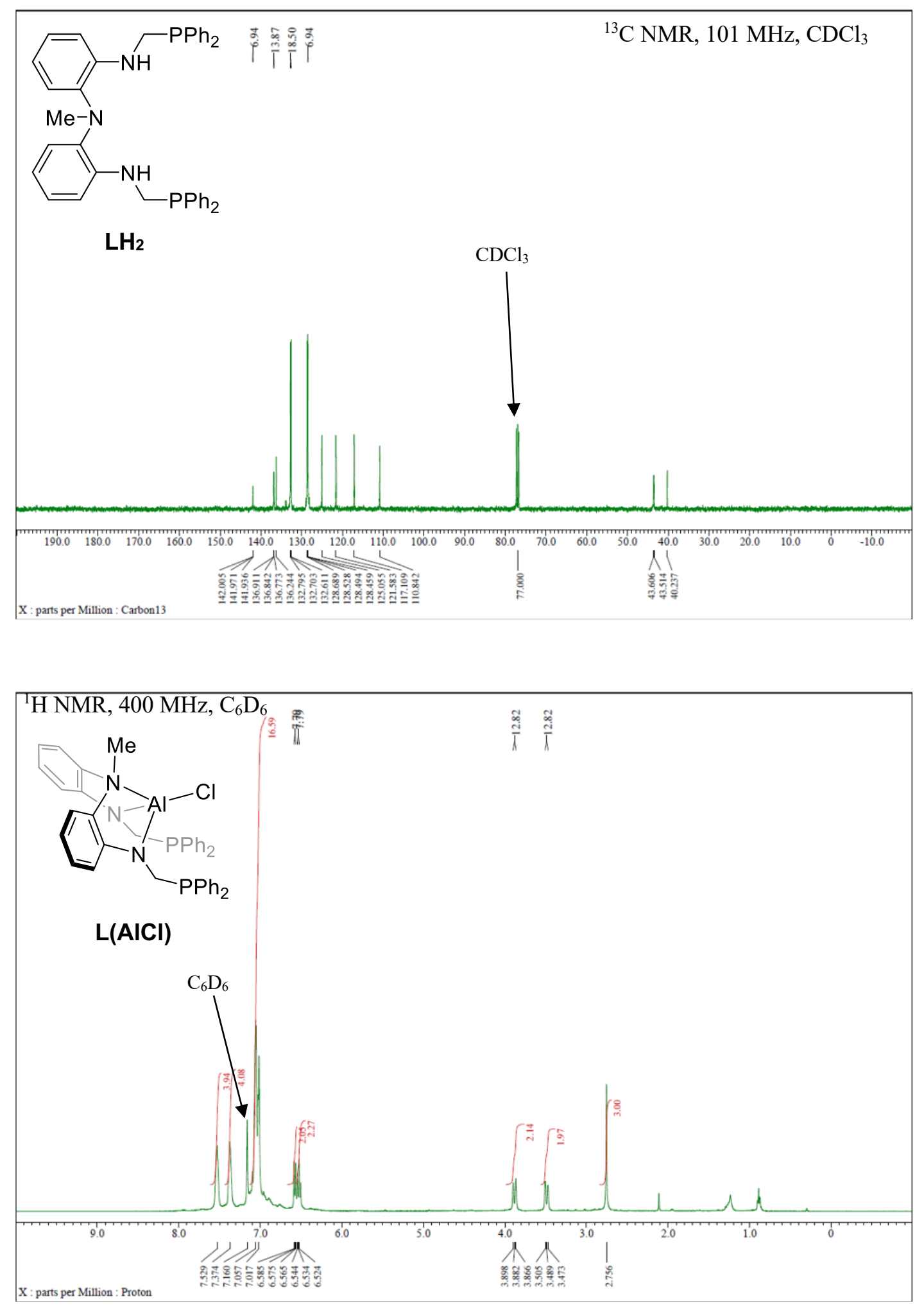

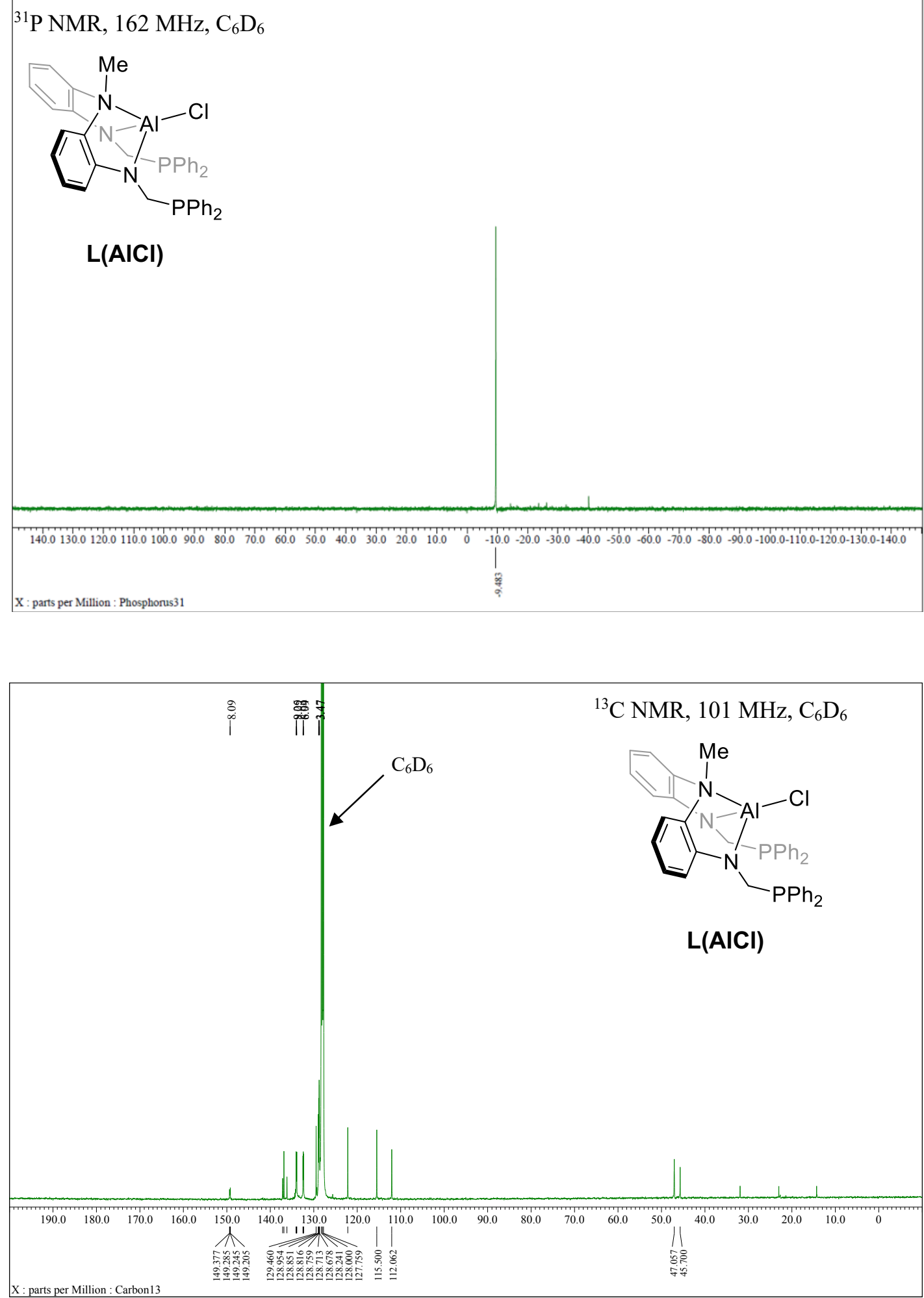

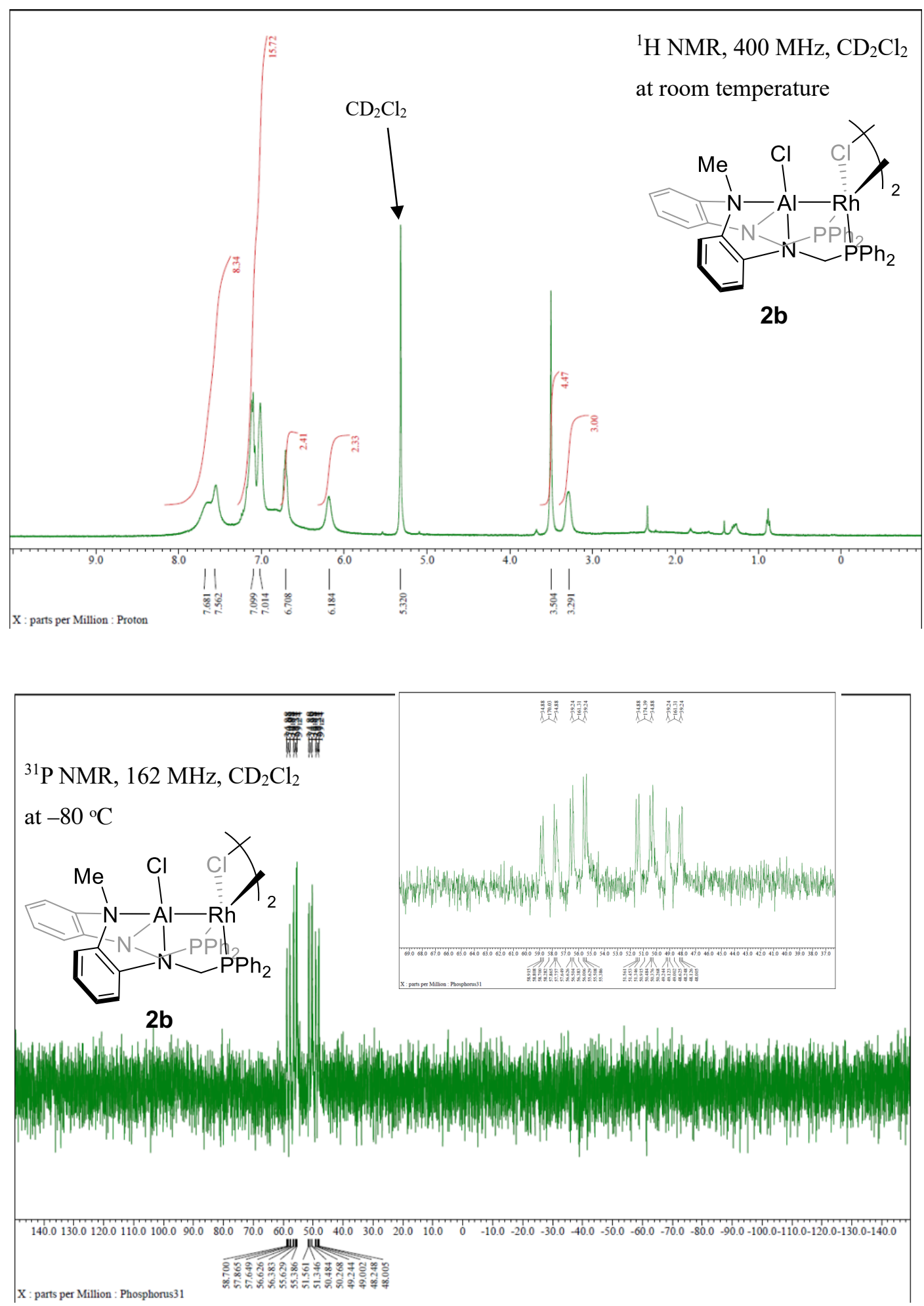